\title{
Market perceptions for expanded opportunities of central Appalachian hardwoods
}

\author{
Liberty Olea Moya \\ West Virginia University
}

Follow this and additional works at: https://researchrepository.wvu.edu/etd

\section{Recommended Citation}

Moya, Liberty Olea, "Market perceptions for expanded opportunities of central Appalachian hardwoods" (2012). Graduate Theses, Dissertations, and Problem Reports. 3519.

https://researchrepository.wvu.edu/etd/3519

This Thesis is protected by copyright and/or related rights. It has been brought to you by the The Research Repository @ WVU with permission from the rights-holder(s). You are free to use this Thesis in any way that is permitted by the copyright and related rights legislation that applies to your use. For other uses you must obtain permission from the rights-holder(s) directly, unless additional rights are indicated by a Creative Commons license in the record and/ or on the work itself. This Thesis has been accepted for inclusion in WVU Graduate Theses, Dissertations, and Problem Reports collection by an authorized administrator of The Research Repository @ WVU. For more information, please contact researchrepository@mail.wvu.edu. 


\title{
MARKET PERCEPTIONS FOR EXPANDED OPPORTUNITIES OF CENTRAL APPALACHIAN HARDWOODS
}

\author{
Liberty Olea Moya
}

Thesis submitted to the

Davis College of Agriculture, Natural Resources, and Design

at West Virginia University

in partial fulfillment of the requirements

for the degree of

Master of Science

in

Forestry

David DeVallance, Ph.D., Chair

James Armstrong, Ph.D.

Annie Peng Cui, Ph.D.

Shawn Grushecky, Ph.D.

Jingxin Wang, Ph.D.

Department of Wood Science and Technology

Division of Forestry and Natural Resources

Morgantown, West Virginia

June 12, 2012

Keywords: Appalachian Region, forest products industry, under-utilized species, hickory, globalization, sustainable-economic development, green marketing, market perceptions, demand for wooden products, trends and innovations. 


\section{ABSTRACT \\ MARKET PERCEPTIONS FOR EXPANDED OPPORTUNITIES OF CENTRAL APPALACHIAN HARDWOODS}

\section{Liberty Olea Moya}

This study investigated how to improve the market potentials of Appalachian hardwoods, specifically within West Virginia. Some Appalachian hardwoods could serve as alternative species for producing various value-added wood-based products. Efficient utilization of these species can lead to reduced manufacturing and consumer costs of major hardwood products. The main objectives of the study included: identifying the major products derived from Appalachian hardwoods, evaluating current and future market trends, and identifying the potential for using hickory as a substitute material in wood products. Additionally, factors that influence both local and international community's wood product purchasing decisions (e.g. price, eco-label certifications, image, design attributes, packaging, promotion and distribution) were investigated. Moreover, this study aimed to assist manufacturers of secondary wood products in positioning and marketing their merchandise during this period of stiff global competition.

Yellow-poplar (Liriodendron tulipifera), red maple (Acer rubrum), sugar maple (Acer saccharum), white oak (Quercus alba), black cherry (Prunus serotina Ehrh.), white ash (Fraxinus americana), hickory (Carya tomentosa), yellow birch (Betula alleghaniensis), aspen (Populus tremuloides) and American beech (Fagus grandifolia) were identified as the top ten under-utilized hardwood species, respectively in West Virginia (based on average annual net change of saw timber volume). Consumers' demand and current product positioning for Appalachian hardwood products were first analyzed to determine the trends and preferences in the present market. Surveys were conducted among the international and domestic communities (i.e. American) at West Virginia University to study the perceptions and market demand for Central Appalachian hardwoods. The 2012 Morgantown Home Show was also used as a venue to check whether there was a difference in the buying behavior of respondents with the intention to buy or already having an interest in wood products. Hickory, as a low-valued species, was further investigated to determine the potential for using it as a replacement for other species in certain wood products.

Keywords: Appalachian Region, forest products industry, under-utilized species, hickory, globalization, sustainable-economic development, green marketing, market perceptions, demand for wooden products, trends and innovations. 


\section{ACKNOWLEDGEMENTS}

I would like to thank the following who had helped and contributed a lot during the course of my study:

Dr. David DeVallance, my mentor, academic and research adviser, for funding this research and for being very supportive in the conduct of this paper;

Dr. James Armstrong, Dr. Shawn Grushecky, and Dr. Jingxin Wang of Wood Science \& Technology Department, and Dr. Annie Peng Cui of Marketing Department at College of Business and Economics, for being so accommodating in all of my queries;

All of the respondents who participated in this study: WVU International \& Local Community; Mr. Dan Dean of Fairmont Kitchen Center, for providing wood samples and furniture display;

For Karrie Ditmore, Sue Dimmick, Will Feisley, Elise Agra, Nan Nan, Dan Hovanec, Cassy Cussins, Geriann Albers, Jagpinder Singh Brar, Missy Braham, Jad Ramadan, Dennis

Pinha, Gemma Hoxie, Moira Reilly, Matt Przybysz, Andrew Dennhardt, Bob-Irene Carubia, Majed and Jehan Zreiqat for the unwavering support in times of needs;

Staff of Trade Shows on: International Housing Furniture Center (IHFC)-2010 Fall Market Show Highpoint, North Carolina; and 2012 Morgantown, West Virginia Home Show;

Mr. Bob Morrison of Old Hickory, for providing photos and insights on hickory production;

Mr. Dave Pinamonti of Heritage Brands, Ms. Cathy Mitchell Parker of Hickory Chair, Mr. Lamar Lehman of Thomasville, Ms. Dory of Hickory Tannery, and to all the industrial practitioners who have shared their valuable knowledge and insights regarding the topic;

All of my WVU professors especially to: Dr. Paula Fitzgerald, Dr. Benjamin Dawson-Andoh, Dr. Rory Jara, Dr. Gloria Oporto, Dr. Kaushlendra Singh, Dr. Allan Collins, Dr. Stuart Moss,

Dr. James Harner, Dr. Yao Li, Dr. Gerry Hobbs and Dr. Stanley Wearden, for all of the guidance in the market research, laboratory works, and statistical analysis;

Dr. Ben Spong of the Appalachian Hardwood Center of WVU for all the initial help;

Faculty and Staffs of the Division of Forestry and Natural Resources: for all of the support; My fellow colleagues: Amy, Clay, Carlos, George, Damon, David, Greg, Jinzhuo, Kumar, Tianmiao, Tuhua, Weiguo, WenJia, Wenshu, and Zhen for the intellectual brainstorming;

Office of International Students and Scholars (OISS) Staff especially to: Dr. Tom Sloane, Dr. Michael Wilhelm, Liz Finklea, Kathy Mayer, Grace Atebe, Diana Abraham, and Kharivat Narayanan, for being my family in WVU who untiringly gave constant moral support and motivations while studying abroad;

To the Newman Catholic Group, Women Across Culture, Co-Environmentors, Graduate Young Professionals, Music Ministry, Co-Catechists, and St. John the Apostles' Parish community: for serving as my home of refuge and passion for service;

To Matthew William Evans, my shining example of a true global leader and manager;

To all my fellow WVU Mountaineers, especially the graduate, and the international students, for always being there to offer genuine support and friendships. 


\section{DEDICATION}

This work is lovingly dedicated to all my loved ones across the globe, especially to my Mom and Dad; my immediate and extended families; former mentors and colleagues; relatives and friends; who had helped me to be where I am now and for constantly believing in the things that I can;

This work is humbly dedicated to the working class that comprises the Forest Products Industry, without whom, I would never be inspired to pursue further studies and add contribution to science and to the society;

For the Wild and Wonderful State of West Virginia and the Appalachian community;

For the future generations to come and for my great love to the Mother Earth, this research is wholeheartedly dedicated;

Lastly, to my constant companion: My Lord, My God and My Best friend for bestowing all of the blessings while seeking the deeper meaning in life and for just being there as my Good Shepherd when I mostly need it. 


\section{TABLE OF CONTENTS}

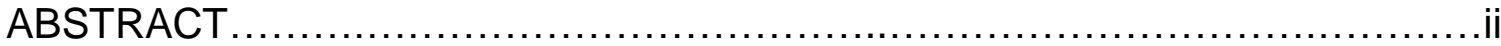

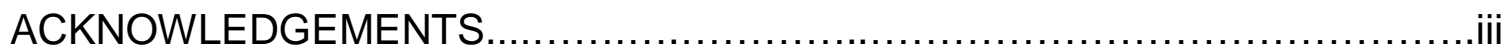

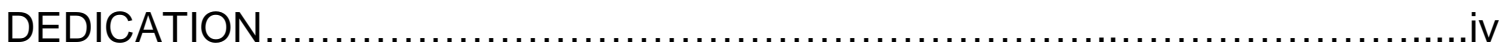

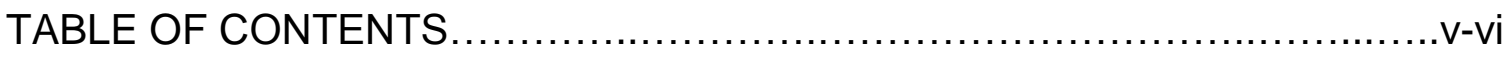

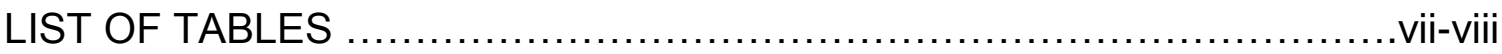

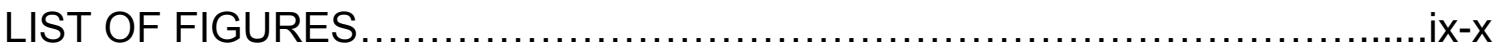

CHAPTER 1: INTRODUCTION AND BACKGROUND INFORMATION............1

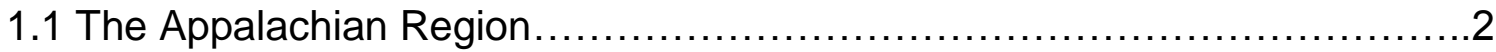

1.2 Economic Assessment of the Appalachian Region.............................

1.3 Definition of under-utilized hardwood species............................. $4-6$

1.4 Market Demand Review on major hardwood products

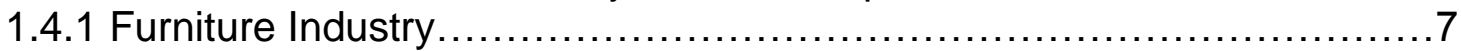

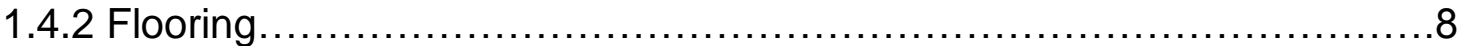

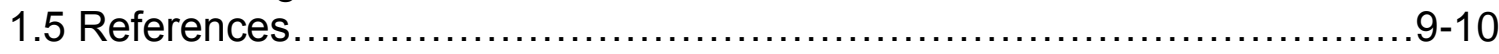

CHAPTER 2: MARKET PERCEPTIONS OF THE INTERNATIONAL COMMUNITY IN WEST VIRGINIA UNIVERSITY ON APPALACHIAN

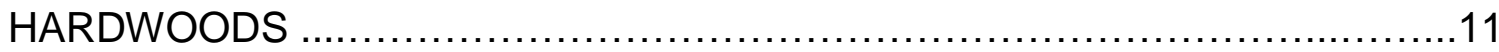

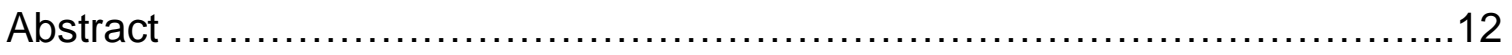

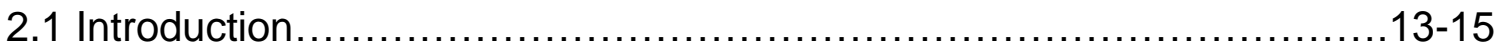

2.2 Materials and Methods............................................................

2.3 Results and Discussion

2.3.1 Demographics and socio - economic profile.......................21-22

2.3.2 Preferences on wooden species, attributes and glaze on finish......22-24

2.3.3 Preferences based on demographics and socio - economic profile..25-28

2.3.4 Wood Identification and Finish Recognition............................28-30

2.3.5 Species Determination and Levels of Expertise......................30-34

2.3.6 Major hardwood products demand projections out of hickory wood...34-35

2.3.7 Factors in wood purchasing decisions................................35-37

2.3.8 Sustainable product designs and concepts on hickory furniture ...........37

2.3.9 Emotional advertisements vs. technical information on promotional

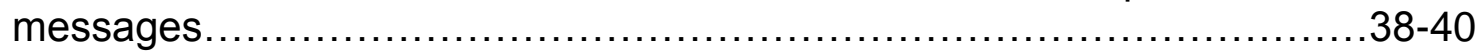

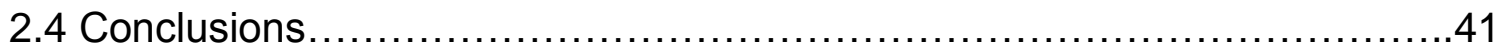

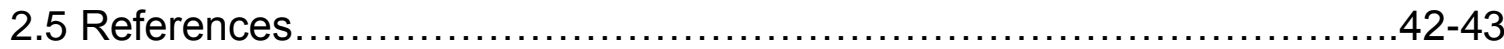


CHAPTER 3: MARKET PERCEPTIONS OF THE LOCAL COMMUNITY IN

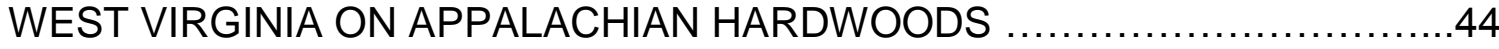

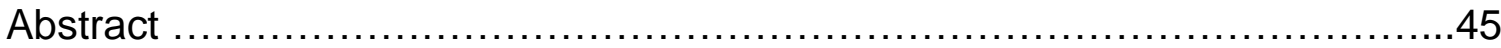

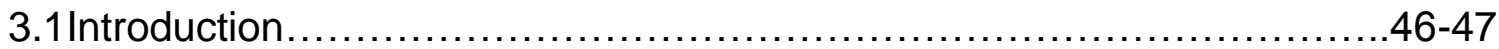

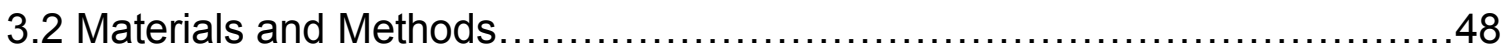

3.3 Results and Discussion

3.3.1 Demographics and socio - economic profile.........................48-49

3.3.2 Preferences on wooden species, attributes and glaze on finish.......49-52

3.3.3 Preferences based on demographics and socio - economic profile..53-58

3.3.4 Wood Identification and Finish Recognition............................58-60

3.3.5 Species Determination and Levels of Expertise.....................60-64

3.3.6 Major hardwood products demand projections out of hickory wood.........65

3.3.7 Factors in wood purchasing decisions................................66-69

3.3.8 Sustainable product designs and concepts on hickory furniture......69-70

3.3.9 Emotional advertisements vs. technical information on promotional messages................................................................

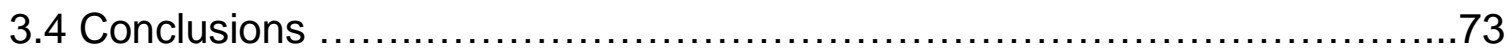

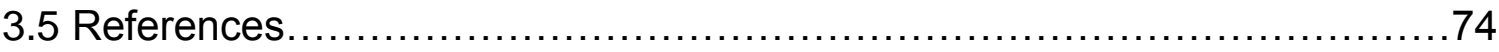

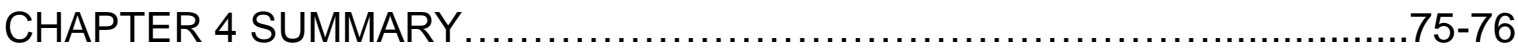

APPENDIX: SURVEY RESEARCH INSTRUMENTS AND OBSERVATIONS. 


\section{LIST OF TABLES}

Table 2.1 Top choice wooden species based on ranking per attribute...........24

Table 2.2 Wood finish preferences of China, India and KSA ...................25

Table 2.3 Gender preference on wooden species most ranked number 1 ......26

Table 2.4 Preferences for walnut and red oak in each age category .............26

Table 2.5 Preferences on commercial species on age group $\geq 30$ years old......27

Table 2.6 Wooden species identification with their most misidentified counterparts by percentage.

Table 2.7 Species determination based on the level of woodworking experience.

Table 2.8 The level of significance in the identification of yellow-poplar with other species based on the discipline of respondents....

Table 2.9 The level of significance in the correct identification of species based on past experience in purchasing furniture within the last five years.

Table 2.10 Nonparametric (Mann-Whitney) test results for level of concern related to purchase decision factors.

Table 2.11 Perceptions on hickory furniture products with tree bark remaining 38

Table 2.12 Impact of promotional ads used to position hickory wood .............39

Table 2.13 Willingness to pay extra for hickory wooden product.................40

Table 3.1 Top choice wooden species based on ranking per attribute...........52

Table 3.2 Gender preference on wooden species most ranked number 1 .......53

Table 3.3 Cross tabulation results based on preference for species with regards to age. .55

Table 3.4 The top most preferred species with regards to age categories.......55 Table 3.5 Preference on commercial species for age group $>30$ years old .....57 Table 3.6 Preference for walnut species over other species based on income.

Table 3.7 Wooden species identification with their most misidentified counterparts by percentage. 
Table 3.8 The level of significance in the species determination based on the level of woodworking experience.

Table 3.9 The level of significance in the identification of yellow-poplar with other species based on the discipline of respondents.

Table 3.10 The level of significance in the correct identification of species based on the past experience in purchasing furniture for the last five years...64

Table 3.11 Nonparametric (Mann-Whitney) test results for level of concern related to top priorities in wood purchasing decision factors of American respondents

Table 3.12 Comparative results on the level of concern between international and local community on wood purchasing decision factors

Table 3.13 Perceptions on hickory furniture products with tree bark

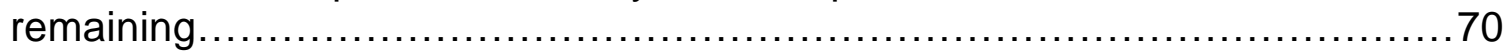

Table 3.14 The impacts of the promotional ads used to position hickory wooden products .71

Table 3.15 Willingness to pay extra for hickory wooden product................72 


\section{LIST OF FIGURES}

Figure 1.1 The Appalachian Region (ARC, 2010)............................. 3

Figure 1.2. Ranking of under-utilized hardwood species based on net growth - removal ratio of saw timber volume, WV (USDA, 2000) .................6

Figure 2.1 Front view of the sample boards (coated with satin polyurethane)

used for species recognition based on appearance

Figure 2.2 Back view of the same sample boards (natural color) used for species recognition based on appearance....

Figure 2.3 Hickory sample boards in glossy $(\mathrm{H})$ and matte $(\mathrm{I})$ finish to determine the glaze preferences of the target overseas market

Figure 2.4 Furniture display cabinet with value-added features

(i.e. with hidden drawers, better screws and hinges)

Figure 2.5 Different wood staining techniques used to compare each of the two sample boards to check the species recognition. 20

Figure 2.6 Over-all preference on wood species of the international respondents

Figure 2.7 Over-all Preference on the glaze of the wood finish .25

Figure 2.8 Percentage ranking of the most preferred species based on age. 28

Figure 2.9 Identification of species with various applied stains. .30

Figure 2.10 Species correctly identified based on the levels of experience in working with wood

Figure 2.11 Species correctly determined based on the past experience in purchasing furniture.

Figure 2.12 Hardwood products that respondents would consider purchasing if made from hickory...

Figure 2.13 Factors that influenced the respondents in wood purchasing decisions.

Figure 3.1 Over-all preferences on wood species among the local community. 50

Figure 3.2 Over-all preferences of the American respondents on the glaze of the wood finish. 
Figure 3.3 Percentage ranking of the most preferred species based on gender.

Figure 3.4 Percentage ranking of the most preferred species based on age group

Figure 3.5 Percentage ranking of the most preferred species based on income group 58

Figure 3.6 Identification of species with various applied stains..... 60

Figure 3.7 Species correctly identified based on the levels of experience in working with wood.

Figure 3.8 Species correctly determined based on the past experience

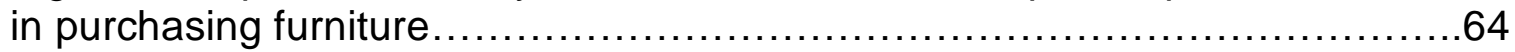

Figure 3.9 Hardwood products favored for hickory wood with natural finish....65

Figure 3.10 Factors that influenced the American respondents in wood purchasing decisions. 66 


\section{CHAPTER 1: INTRODUCTION AND BACKGROUND INFORMATION}

The wise use of under-utilized, low valued hardwoods could balance forest composition by creating a homogeneous demand on Appalachian species. Using alternative species would also help minimize the dependence on traditional species. Moreover, from an economic standpoint, removing and using wood species that are typically left in the forest maximizes value of woody materials.

The reduced domestic market demand for construction and building materials has affected major hardwood industries like furniture, flooring, and wood paneling. Export markets however, have shown greater potential due to the rise in the emerging markets like China, Russia, India and other countries that consider American furniture as a brand status symbol (Scelfo 2007). On the other hand, value-added services are important to customers in developed countries. U.S. manufacturers therefore, should think of innovative ways to continuously improve their products from product development to the selling and item disposal (Buehlman and Schuler 2009).

Globalization has resulted in intense competition between U.S. furniture manufacturers and their offshore counterparts, particularly in China and Southeast Asia (Bowe and Bumgardner 2004). Moreover, furniture companies in the U.S. either moved their production overseas to take advantage of the cheap labor force or engaged in direct outsourcing to provide a more competitive price in the global market. The emergence of the green economy, however, may change the furniture market trends (Buehlman and Schuler 2009). Costs reduction and product differentiation in terms of quality, features and service are among the categories that could increase the competitive advantage of a firm (Porter 1985). The rise in niche markets for customized products and services now becomes essential as customers demand and expectations increased (Esty and Winston 2009). In value chain assessment, the use of local materials are

viewed more sustainable, as this may mean lower price, faster delivery, reduced transportation costs and carbon emissions (Esty and Winston 2009; Buehlman and Schuler 2009, Porter 2010). 
Timber resources are natural assets of the Appalachian region. For many species, growth has far exceeded the demand. Hickory species for instance, are often left in the forest due to their low stumpage price (Hardwood Weekly Review, 2010). It has also been identified as one of the most underutilized species (Luppold and Baumgras 2001, McDaniel 2003). Thus finding new ways to use hickory or to increase hickory's economic utility value are important.

The main objectives of this project were to: (1) assess the present economic situation of the Appalachian hardwood industries; (2) investigate the perception of important Appalachian hardwood species; 3) explore the market opportunities of identified under-utilized hardwood species in the Appalachian region; and (4) evaluate the demand for value-added products from underutilized Appalachian hardwoods.

\subsection{The Appalachian Region}

The Appalachian region is a 205,000 - square mile continuous ridge of the Appalachian Mountains. It is home to 25 million people in 420 counties of 13 states: Alabama, Georgia, Kentucky, Maryland, Mississippi, New York, North Carolina, Ohio, Pennsylvania, South Carolina, Tennessee, West Virginia and Virginia. Forestry is one of the major sources of livelihood. An assessment therefore of the region's natural assets is a must. 


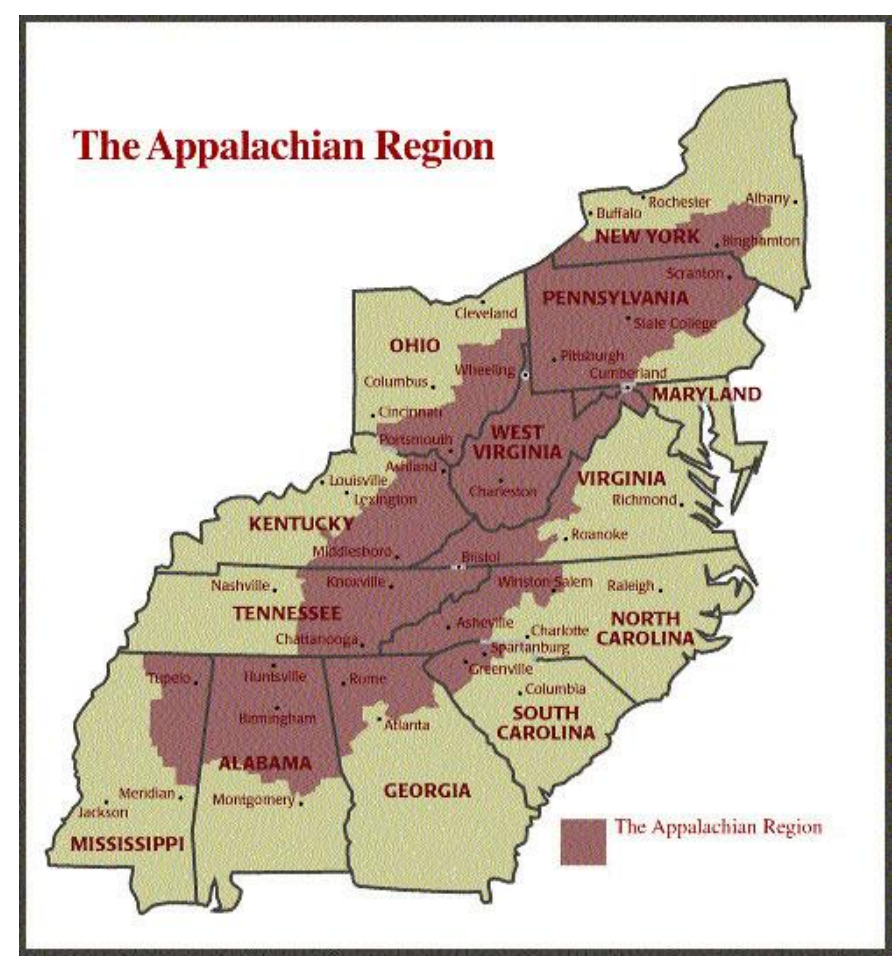

Figure1.1 The Appalachian Region (ARC, 2010)

\subsection{Economic Assessment of the Appalachian Region}

Today, 65\% of the Appalachian region is covered by 86 million acres of forest, the majority of which is 83\% hardwoods (ARC 2010). Appalachia is a major source of the nation's hardwood resources and comprises approximately one-third of the available U.S. Hardwoods (ARC 2010). Prices of existing homes continue to decline and the demand is still low for new construction and wooden furnishings (Buehlmann et al. 2011). It is therefore necessary to find innovative ways to improve the market potential for Appalachian hardwoods.

Global competition has lead to a decreased domestic demand for the Appalachian hardwoods and an increase of competition for supplying lumber overseas (Buehlmann 2003). The hardwood industry needs to be more innovative in marketing strategies to promote business continuity (Naka et al. 2009). 


\subsection{Definition of under-utilized hardwood species.}

In this research, under-utilized hardwoods are species that grow abundantly in the region but their growth has outpaced the demand. According to the National Hardwood Lumber Association (NHLA), identification of marketing opportunities alongside efficient utilization of hardwoods, are among the top research need priorities (Milauskas et al. 2005). Research related to profitable utilization of hardwoods has been a major interest among forest scientists and economists. Hardwood species remain under-utilized for the following reasons: (1) when the lumber price becomes low-valued in the market as compared with similar products, (2) when the wood is classified as low grade based on grading system standards and end-use, (3) when the growing stock is more than the demand and (4) when there is a lack of production techniques and processes to fully develop the utilization of hardwoods (Bumgardner and Luppold 2003).

A low-valued wood is greatly influenced by the law of supply and demand. Consumers' preferences too, often dictate the need and popularity of a certain wood species. Red oak for instance, is now one of the most important species imported in China from the U.S. (Wang et al. 2010). The emerging middle class of China is projected to invest more on home ownership as well as with other construction materials and home furnishings (Farrell 2006). The market value of red oak species was lower from the 1950's to 1960's, but deliberately became a high-value species by the late 1980's (Bumgardner et al. 2003). Red oak has primarily become popular for hardwood flooring, furniture and cabinetry in other parts of the world. The popularity of red oak has been assisted through constant promotion of red oak's abundance, aesthetics and workability (AHEC 2006). Other species are less valued due to some undesirable working properties (e.g., difficult to machine). Hickory, for example, has the lowest stumpage price when compared with other commercial wooden species (Timber Market Report WV 2010). However, there was a 50\% increase in hickory lumber prices due to the popularity for kitchen cabinets in the 1990s 
(Barret, G., et al. 2001, Bumgarder et al. 2003). This suggests that low price trends of a certain species can reversed when there is a greater demand.

A low-grade wood is a lumber classification based on physical properties, efficiency and serviceability according to agreed upon quantitative categories (Bumgarder et. al 2003). There are discrepancies on the definition of low-grade lumber among hardwood manufacturers (Cumbo et al. 2003). Other major challenges that U.S. hardwood manufacturers now face are market decline and increased supply of low-grade lumber. As the quality of higher grade hardwood lumber decreases, the supply of low grade lumber tends to increase. There is a strong need therefore, for lumber manufacturers to produce high-value products from low grade lumber and to look for more reliable markets (Shepley et al. 2004, Wang et al. 2004). Most sawmills that produce low grade lumber deal only with a single market, thus market stability and a greater profit margin are of major concerns (Cumbo et al. 2003). Low-grade lumber usually results in lower yield and requires extra processing time (Bumgardner et al. 2003). Since the supply of low-grade lumber is now on the rise, innovations on improved utilization and increased efficiency are necessary (Bumgarder et al. 2003, Shepley et al. 2004). Generally, low-grade lumber, when mixed with other materials, creates valueadded wood products. Other current practices that add value to wood include: green dimensioning, manufacturing of composite materials, and finger jointing (Shepley et. al, 2004). Given the challenges that low-grade lumber industries now face, there is a need to improve and diversify markets. Other small markets include: stakes, fence boards, international flooring and construction markets, farm/shop lumber, manufactured pallet parts, custom sawn boards, and mine timbers (Cumbo et al. 2003).

The net growth to removal ratio is a good indicator to determine forests sustainability. For instance, the Appalachian forests show a positive trend of net removal ratio and have the capacity to supply raw materials for the hardwood manufacturing industries (Parsons 2003). Figure 2, shows the very high net removal ratio of under-utilized saw timber species in the state of West Virginia. 


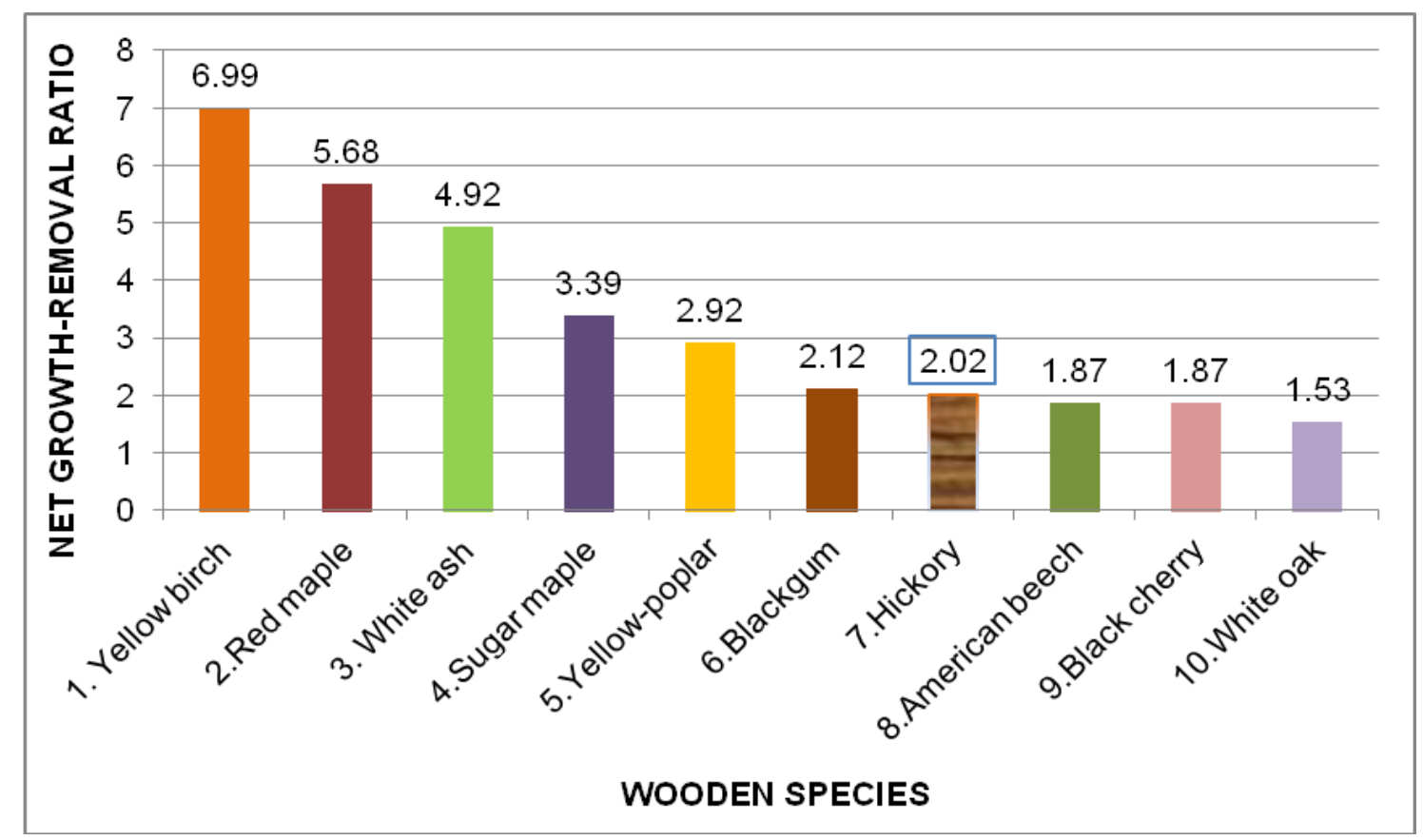

Figure1.2. Ranking of under-utilized hardwood species based on net growth - removal ratio of saw timber volume, West Virginia (USDA, 2000).

Improved wood processing technologies to achieve higher efficiencies are important factors for enhancing the marketing of under-utilized species. For instance, a lack of identified markets and poor investments in technology may lead to wasting of some hardwood species. Red alder, as an example was once an under-utilized species until it became popular in the northwestern United States. According to Youngs (2001), some constraints in the marketability of under-utilized species include: undependable supply, presence of technical information, availability of small trial volumes, and low trial prices.

Wood processing information is important in terms of produce quality products from under-utilized species. Selection of species will likely depend both on the functionality and market acceptability of the product. Moreover, wood property information is also essential to penetrate quality standards of global market (Barany 2003). Through increased promotion, red oak has now become one of the most marketed hardwoods in other regions specifically Mexico and China (AHEC 2006). 


\subsection{Market Demand Review on major hardwood products.}

\subsubsection{Furniture Industry}

\section{a. Demand Determinants}

Four factors that determine the USA market demand for furniture include: (1) household disposable income, (2) remodeling sentiment, (3) new home construction and (4) price (IBIS World 2010). As an individual's income level rises, the demand for furniture items typically increases. Over the last five years, imported furniture is often cheaper, and can lead to a price deflation for domestically produced furniture pieces (IBIS World 2010).

\section{b. International Trade}

According to ARC (2010), the furniture industry in the Appalachian region has export advantages due to: (1) proximity to raw materials; (2) reputation for quality work; (3) furniture designs and; (4) well established manufacturing firms with production capabilities that cater to niche markets. The top furniture importing countries are Canada, Germany, Saudi Arabia and Japan (ARC 2010). The Appalachian furniture industry is self-sustaining since more than 50 percent of raw materials are bought within Appalachia, and over 80 percent of the outputs are sold within Appalachia (ARC 2010).

\subsubsection{Flooring}

\section{a. Export Demand}

China is a major consumer market for U.S. exports, as wood flooring consumption is emerging in this market. It is expected that sales of certified wood products in the U.S. market will increase as China needs to import wood from sustainable and legal sources of timber (Wang et al. 2010). Trading was strengthened because of the newly amended Lacey Act. Moreover, the Chinese market is transitioning to alternative North American suppliers because Russia is now imposing additional taxes (Fisher 2010). Given the importance of the 
emerging international community for the purpose of this study, it was important to investigate the perceptions of individuals from an international background. Information related to international perceptions of certain species will provide insight into marketing techniques and assist manufacturers in marketing their products to the international community living within the U.S. 


\subsection{REFERENCES}

American Hardwood Export Council. 2006. Red Oak Revisited. Retrieved August 14, 2011 http://www.ahec.org/publications/AHEC\%20publications/AHEC_Red_Oak_Final.pdf.

American Hardwood.2010. Sustainable American Hardwoods, A guide to species.

Appalachian Hardwood Manufacturers Inc., Resource Guide.2010. p.3.

Appalachian Regional Commission. 2010. The Appalachian Region: Economic Status of Appalachian counties Retrieved March 15, 2011, from http://www.arc.gov/appalachian_region/TheAppalachianRegion.asp

Appalachian Regional Commission. 2010. Moving Appalachia Forward: Strategic Plan 2011 2016, p.25.

Appalachian Regional Development Initiative Report. 2010. Economic Assessment of Appalachia. pp. 8 - 12.

Appalachian Transition. 2011. Retrieved April 25, 2011 from http://appalachiantransition.org/forestry.

Barret, G., J. Baumgras, and W. Luppold. 2001. Utilization of the Eastern Hardwood Resource by the Hardwood Sawmilling Industry. Northern Journal of Applied Forestry.18(2):3-4.

Barany,M., A.L.Hammett, and P. Araman.2003. Lesser used wood species of Bolivia and their relevance to sustainable forest management. Forest Products Journal. 53 (7/8):1- 6.

Bowe, S., and M. Bumgardner.2004. Consumers perceptions and knowledge of common furniture woods. USDA Forest Service: Proceedings 14th Central Hardwood Conference. Northeast Research Station: 404-410.

Buehlmann, M., M. Bumgardner,A. Schuler and M. Barford.2007. Assessing the impacts of global competition on the Appalachian hardwood industry. Forest Products Journal. 57(3):89-93.

Buehlmann, U., M. Bumgardner, A. Schuler, and K. Koenig.2011. Housing and the Wood Industry, Trends and Market Conditions W \& WP. Woodworking Network.com, p.24.

Buehlmann, U. and A. Schuler. 2009. The U.S. household furniture industry: Status and opportunities. Forest Products Journal. 59(9):27.

Bumgardner, M., and W. Luppold. 2003. What is low-value and/or low-grade hardwood?: Forest Products Journal. 53(3):54-59.

Cumbo, D, R. Smith, and P. Araman. 2003. Low-grade hardwood lumber production, markets, and issues: Forest Products Journal. 54(12):15-23.

Esty, D. and A. Winston. 2009. Green to Gold. How smart companies use environmental strategy to innovate, create value, and build competitive advantage. John Wiley \& Sons Publication. Hoboken, New Jersey. pp. 15, 62-64, 101-303.

Farrell, D., U. Gersch, and E. Stephenson. 2006. The Value of China's Emerging Middle Class. The McKinsey Quarterly Special Edition. 
Hardwood Weekly Review, Last Quarters.2007 - 2010.

IBIS World Industry Report 33712. 2010. Household Furniture Manufacturing in the US. http://www.ibisworld.com/industryus/productsandmarkets.aspx1999-2010.

McDaniel, P. 2003. Opportunities for the utilization of non - traditional species in wood based component manufacturing. M.S. Thesis, Virginia Polytechnic Institute and State University, Blacksburg, VA.

Milauskas, S., B. Anderson, and J. McNeel J. 2005. Hardwood industry research priorities in West Virginia. Forest Products Journal. 55 (1):28-32.

Naka, K., B. Parsons, and A. Hammett. 2009. Hardwood lumber industry in the Appalachian region: Focus on exports. The Forestry Chronicle. 85(1): $75-81$.

Parsons, B. 2003. An Examination of Appalachian Forest Products Exports. M.S. Thesis, Virginia Polytechnic Institute and State University, Blacksburg, VA.

Porter, M. 2010. Reflections on a Hypothesis: Lessons for Policy, Research and Corporate Practice. Presentation at the Porter Hypothesis at 20 Conference: Can Environmental Regulation Enhance Innovation and Competitiveness? Montreal, Canada. Retrieved June 3, 2012 from http://www.isc.hbs.edu/soci-environmental.htm.

Porter, M. 1991. America's Green Strategy, Scientific American 264. (1991):168.

Porter, M., and C. Van der Linde, C. 1991. Green and Competitive: Ending the Stalemate. Harvard Business Review. 73(1995):120-134.

Porter, M. 1985. Competitive Advantage: Creating and Sustaining Superior Performance. New York: Free Press.

Scelfo, J. 2007. High Point Hears Cheers from Abroad. New York Times. Retrieved March 29, 2012 from: http://www.nytimes.com/2007/10/11/garden/11HighPoint.html

Shepley, B., J. Wiedenbeck, and R. Smith. 2004. Opportunities for expanded and higher value utilization of No. 3A Common hardwood lumber: Forest Products Journal.54 (9): 77 - 85.

Timber Market Reports Last Quarters. 2007 - 2010.

USDA on Growth and Harvest Volume. Retrieved October 15, 2010, from http://www.fas.usda.gov/gats/default.aspx

Wang, J., J. Wu, D. DeVallance, and J. Armstrong. 2010. An analysis of Appalachian Hardwood Products in the Chinese Market: Wood and Fiber Science. January 2010. pp. 72-73.

Youngs, R. 2001. Diversity, Productivity, Profitability, Sustainability, and the Tao of Underutilized Species: Forest Products Journal. 51(1):29-35. 
CHAPTER. 2

MARKET PERCEPTIONS OF THE INTERNATIONAL COMMUNITY IN WEST VIRGINIA UNIVERSITY ON APPALACHIAN HARDWOODS ${ }^{1}$

Liberty Olea Moya

${ }^{1}$ To be submitted to Forest Products Journal 


\title{
ABSTRACT
}

\section{MARKET PERCEPTIONS OF THE INTERNATIONAL COMMUNITY IN WEST VIRGINIA UNIVERSITY ON APPALACHIAN HARDWOODS}

\author{
Liberty Olea Moya
}

This study investigated perceptions of the international community living within the U.S. on Appalachian hardwoods. A sample of 205 respondents, who were at least 18 years old, from the international community of West Virginia University (i.e. foreign students, international faculty members, staffs and their relatives) were surveyed. The seven hardwood species were evaluated based on thoughts and perceptions of the respondents. An assessment on the physical attributes of the wood species was performed to determine if lowvalued species such as hickory would have the same market acceptability as other traditional species. Differences based on gender, age, levels of experience and expertise in purchasing wooden products were observed. Results showed that walnut, red oak and hickory were the most preferred wooden species. Yellow-poplar and hard maple were the species most correctly identified. Hickory with a "spice" finish was perceived to be red oak with a honey spray wood stain. Darker color wood samples (walnut and hickory) were perceived more expensive. On the other hand, lighter color wood samples (yellow-poplar, hard maple, and soft maple) were perceived more calm and sustainable. The international community was more likely to invest on hickory furniture that had a portion of tree bark. These designs were viewed sustainable, however old-fashioned. Generally, the respondents preferred matte over a glossy finish. The most preferred hardwood products made from hickory included: doors, kitchen cabinets and wardrobe cabinets. Both technical information and emotional ads can be used to promote under-utilized species among the international community. Technical ads were more effective in promoting the durability of hickory than emotional ads. Results from this study, could help secondary wood manufacturers in their product designs and promotional marketing strategies when using under-utilized species.

Keywords: Under-utilized species, perceptions and preferences, hickory species, purchasing decisions, sustainable product designs, promotional messages. 


\subsection{INTRODUCTION}

The primary aim of this study was to identify the market opportunities of hardwood species in West Virginia, with a focus on low-valued and underutilized species. Under-utilized Appalachian hardwoods could serve as alternative feed stocks for value-added wood products in major hardwood industries (Bush et al. 1992, Wang et al. 2004). These species could help promote the sustainable use of wood as a renewable resource. The use of under-utilized species to manufacture value-added wood products will improve marketability of Appalachian hardwoods. Under-utilized hardwood species are not yet properly positioned in the market due to lack of popularity among design groups and wood product manufacturers.

Using growth-removal ratio as the principal basis of ranking, hickory species is ranked as the seventh most under-utilized Appalachian hardwood species in West Virginia. This was further supported by the average annual net change of saw timber volume in West Virginia. Hickory, as one of the most identified under-utilized species can be a good substitute material for commercial wood products. While hickory may be considered a high-grade wood, it also has a low stumpage price (Hardwood Market Reports 2010). By studying the perception of hickory and other Appalachian hardwood species, ways to use hickory as a substitute material can be identified.

Timber harvesting affects the relative rate of utilization among species in the forest. Hickory species for instance, has lower levels of utilization and indicates an increasing inventory in the forest relative to its natural growth or decline (Luppold and Baumgras 2001). Hickory is still considered an underused Appalachian hardwood because of its low value in the timber market. In the current economic time, it is important to find ways to further utilize and add value to under-utilized, low-valued hardwood species. In this downturn market situation, there exists opportunities for investment in low cost timber. Hickory has a low stumpage price due to many factors (e.g., low demand, machinability, higher density). Issues impacting the use of hickory may be more related to a 
reluctance to saw hickory than with consumer acceptance. Hickory lumber price and demand increases as the grade of lumber is higher (Luppold and Baumgras 2001). This indicates that higher grade hickory may be more preferred when used in wood products.

Hickory also remains under-utilized because it is harder to work with and more difficult to machine and glue, as compared to other Appalachian hardwoods. Hickory's longer drying time and tedious lumber selection process adds additional costs (Appalachian Hardwood Manufacturers 2010). Hickory also has a tendency to split when nailing or screwing it in place and requires pre-drilling pilot holes (American Hardwood 2010). Even with some of the processing and use limitations, harvesting hickory must be viewed as a valueadded investment. Sawmill owners need to identify hickory's full asset value to continue investing in timber. Improved customer acceptance of hickory products can compensate the extra harvesting and manufacturing costs. Alternative processing techniques (e.g., steam bending, finger jointing, wood finishing, etc.) and innovative product designs must be considered to achieve a sustainable economic timber resource (ARC 2010). Wood finishing techniques, for instance, can modify the wood color to meet customers' tastes and preferences.

Hickory has been popular in the kitchen cabinet and flooring industries due to durability and added consumer appeal. The choice for this species could be attributed to the consumer preferences on quality, and functionality of the product (McDaniel 2003). According to Bumgardner et al. (2011), the use of local over imported wood species is more sustainable as customized orders limits inventory. Moreover, reduced transportation costs can lead to more flexibility and just-in-time (JIT) production. Through using locally sourced and JIT production, the use of hickory for customized products will have a higher probability of success.

The objectives, therefore of this study were to: (1) measure perceptions of commercially important Appalachian hardwood species (2) investigate the market potentials of hickory as an alternative species; (3) identify the major potential end-use products that could be derived from hickory; (4) analyze the 
market preferences of the international community on wood products and (5) determine the type of promotional messages that best position Appalachian hardwoods for marketing to the international community in the U.S. market.

\subsection{MATERIALS AND METHODS}

The survey was conducted from February 27 - March 15, 2012. The international community of West Virginia University were asked to answer a survey questionnaire (refer to Appendix 1.1) during an International Dinner Event. Questionnaires were also distributed in areas with high foot traffic of foreign nationalities that include students, faculty members and staff.

A total of 205 respondents took part in the study. All respondents were at least 18 years old and had foreign nationalities. Respondents of 18 years old and older were preferred, as this group has the purchasing power to invest or at least has interests on buying wood products. Basic socio-demographic questions were asked and related to wood purchasing decisions and preferences. Respondents included prospective consumers, industrial practitioners and people from academia. A pre-test was conducted to finalize wording of all the questions. For instance, some of the English words like "cold or warm" which were used in previous studies resulted in varied associated meanings in different countries; therefore these questions were change to "calming effect" instead.

Participation was based on invitation (not mandatory) and it generally took an average of 15 minutes to complete the survey. Respondents who participated in the survey received one set of "American Patriotic Playing Card" (see Appendix 1.2). Seven wood sample boards each measuring 5.0 inches (width) $\times 7.0$ inches (length) $\times 0.5$ inches (thickness) were used to evaluate the following commercial wood species: cherry (Prunus serotina Ehrh.), walnut (Juglans nigra L.), northern red oak (Quercus rubra L.), hickory (Carya tomentosa), red maple (Acer rubrum), sugar maple (Acer saccharum) and 
yellow-poplar (Liriodendron tulipifera). A random sequence generator was used to sequence the alphabetical codes of the wooden samples. The order generated corresponds to soft maple (A), red oak (B), hickory (C), hard maple $(D)$, walnut $(E)$, cherry $(F)$, and yellow-poplar $(G)$ (Figure 2.1). These were all then placed on top of a blank table to avoid biases on background of colors. Only the common names of the species were shown on the questionnaire. Respondents were asked to identify the wooden samples based on their own thoughts and perceptions.

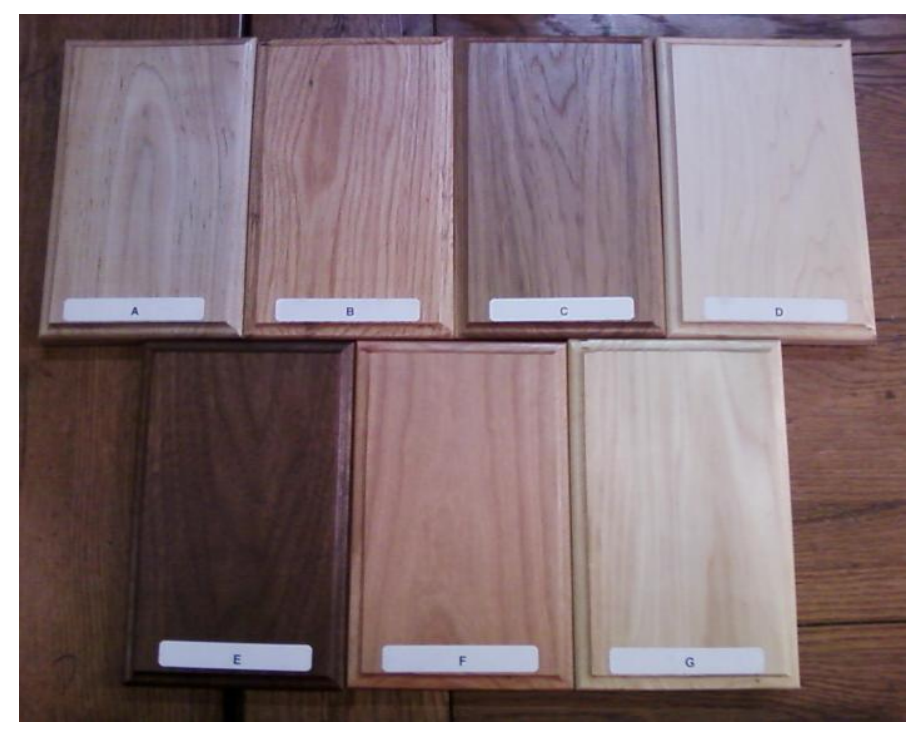

Figure 2.1. Front view of the sample boards (coated with satin polyurethane) used for species recognition based on appearance. 


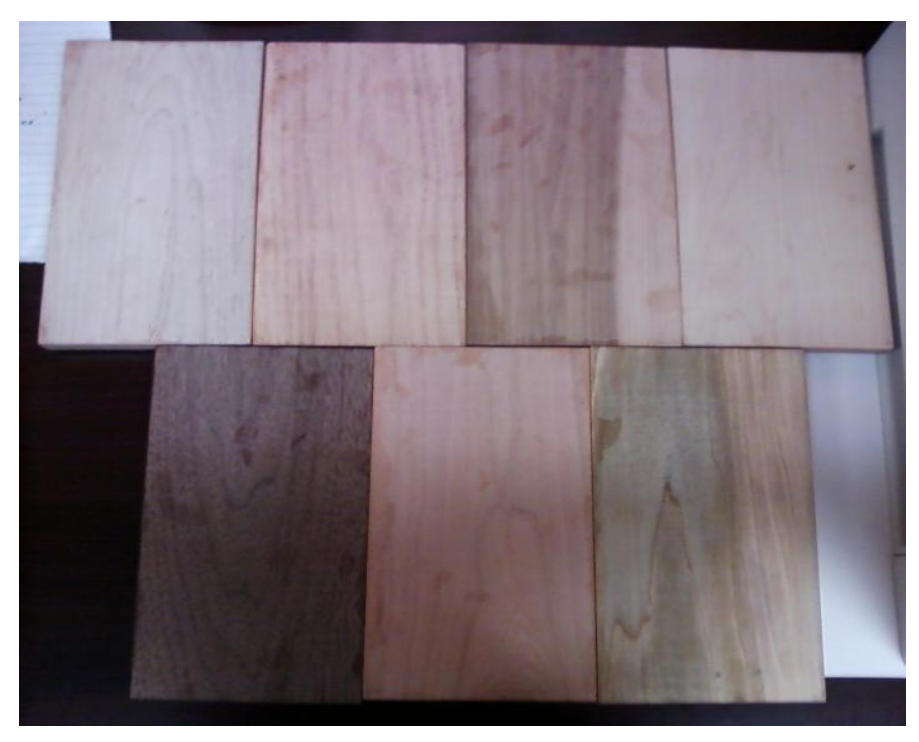

Figure 2.2. Back view of the same sample boards (natural color) used for species recognition based on appearance.

The front view of the sample boards were all finished with two coats of satin polyurethane. This was to give the actual look of a typical finished endproduct. Respondents were given a chance to examine the wooden sample boards before ranking them in order ( $1=$ Most liked, $7=$ Least liked), according to their own choice and preferences. Of the total respondents, only $59 \%$ had completely ranked the species from 1 to 7 . These could possibly be due to: loss of interest in the ranking of wood, time constraints involved when filling-out the survey, and not understanding the questions which were only written in English.

Wood property perceptions for every selected species were examined to assist in future product design and in creation of promotional messages that are appropriate for consumers of foreign nationalities living in the Central Appalachian region. Respondents were asked to rank in order the top three wood samples of their choice based on the following attributes: durability, expensive look, elegant design, formal look, modern style, calming effect, ecofriendly. These categories were used to represent the theoretical factors that were used in the past study (Bowe and Bumgardner 2003) and to describe 
household furniture based on quality, price, style, visual elements, and environmental considerations.

Finish preference on hickory species was also analyzed. Respondents were asked whether they prefer a glossy $(\mathrm{H})$ or a matte (I) finish on the hickory sample (Figure 2.3). Also, while referencing the actual hickory sample (I), respondents were asked to indicate which wood products they would consider using if made from hickory.

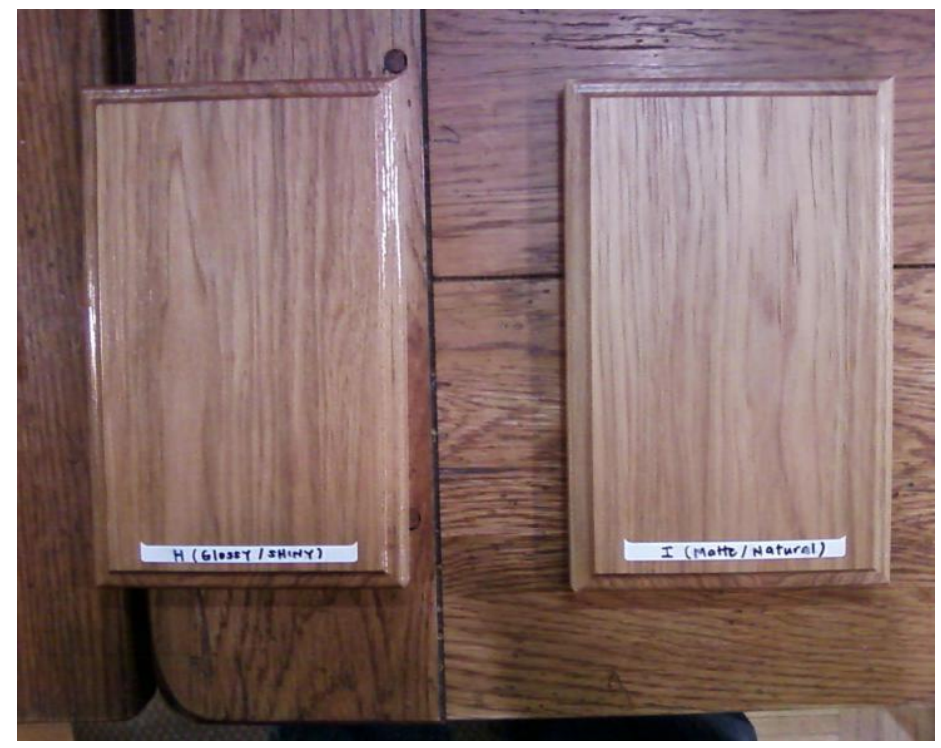

Figure 2.3. Hickory sample boards in glossy $(\mathrm{H})$ and matte (I) finish to determine the glaze preferences of the target overseas market.

Wooden sample boards used to evaluate the perception of wood species with varying finishes and the furniture display cabinet were prepared by Mountaineer Wood Craft (Fairmont Kitchen Cabinet Center). A furniture display cabinet with value-added features was shown to evaluate the respondents' level of concerns when purchasing wood household products (Figure 2.4). 


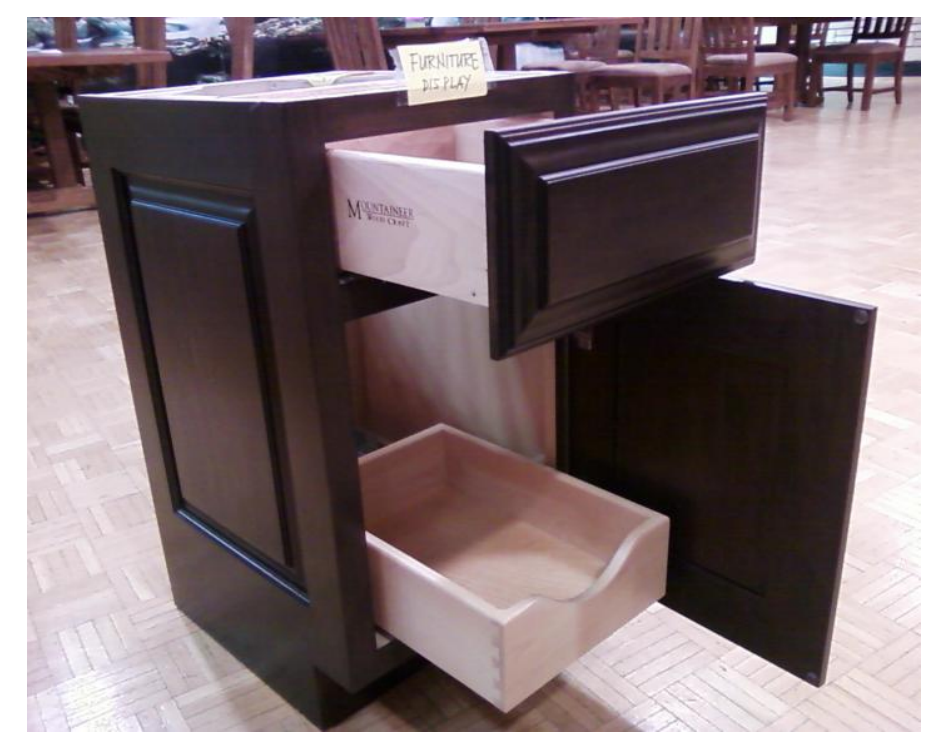

Figure 2.4. Furniture display cabinet with value-added features (i.e. with hidden drawers, better screws and hinges).

Among the factors that the respondents were asked to consider were: price, wood finish, color, natural grain, item functionality and safety, accessories, eco-labels, product labels, and product information. To check the expertise and level of experience in purchasing wooden products, respondents were asked to whether wood samples (with relatively similar finish) were of the same species (Figure 2.5). This method was also used to check whether the differences in wood species in a particular product matters with the consumers. Also, these questions were designed to determine whether using a wood finishing technique on hickory resulted in a product that was perceived to be another species. 


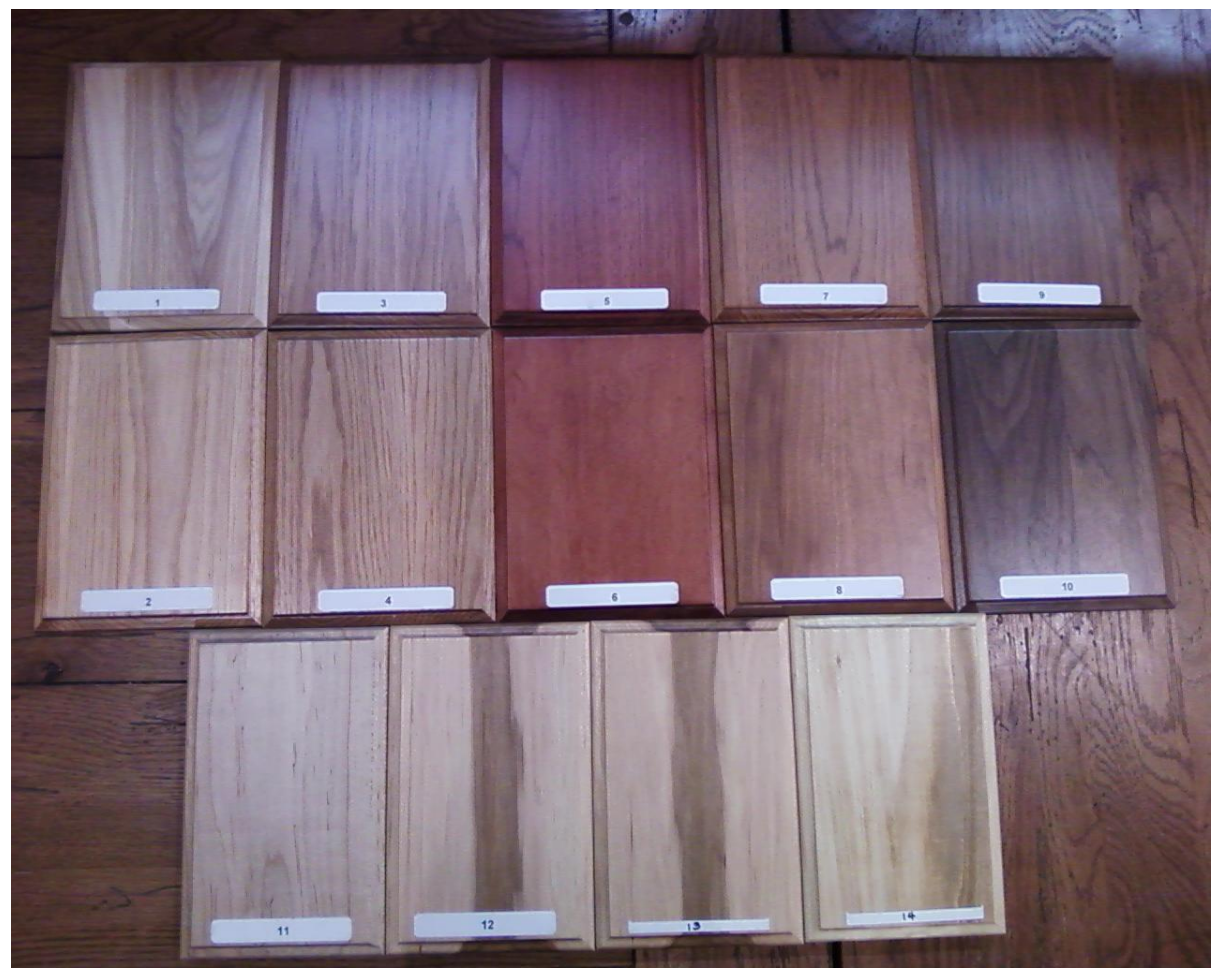

Figure 2.5. Different wood staining techniques used to compare each of the two sample boards to check the species recognition.

Each of the two sample boards of almost similar finish were shown to the respondents. The back portion of these wooden samples were all unfinished and unlabeled (see Appendix 1.3) which gave respondents a chance to examine thoroughly the sample boards. The following wooden samples were compared and asked if they are of the same species: Number 1 and 2 (Hickory Natural vs. Hickory Honey Spray), 3 and 4 (Hickory Spice vs. Red Oak Honey Spray), 5 and 6 (Hickory Harvest vs. Maple Harvest), 7 and 8 (Hickory Amber vs. Cherry Ginger), 9 and 10 (Hickory Autumn vs. Walnut Natural), 11 and 12 (Hickory Natural vs. Hard Maple Natural), 13 and 14 (Hickory Natural vs. Yellow-poplar Natural).

A poster of a furniture collection "with and without" the tree bark remaining (see Appendix 1.3) on the lumber was shown to the respondents to check current insights on hickory product designs. The respondents were asked 
whether furniture with tree bark was considered more modern and or viewed as sustainable, without them knowing that these are made of hickory species.

The last part of the questionnaire evaluated the impacts of emotional based ads and technical information on the respondents' perception of hickory. Specifically, after reading the advertisements respondents were asked about their perception of hickory, interest in buying hickory, and their willingness to pay extra for hickory wood products.

The statistical software program NCSS (Hintze, 2009), was used to analyze the descriptive statistics on cross tabulations and frequency reports. The z-test values were used in the analysis of proportions. Statistical significance was evaluated at alpha level=0.05. Results on frequency data were rounded to the nearest whole number. Analysis of medians was also used to determine the variables that gave the highest impact factor in wood purchasing decisions. The T-Test (test of two samples) procedure through the Nonparametric (Mann-Whitney $U$ or Wilcoxon Rank-Sum Test for Difference in Medians) was used to check the statistical significant difference in each factor.

\subsection{RESULTS AND DISCUSSION}

\subsubsection{Demographics and socio - economic profile}

Respondents were comprised of $55 \%$ male, $29 \%$ female and $16 \%$ with non-response to gender. The age distributions of the respondents were as follows: 18 to 23 years old (42\%), 24 to 29 years old (35\%) and greater than 30 years old $(21 \%)$. Two percent of the respondents had their age remain undeclared. There were $72 \%$ single respondents, and $21 \%$ married while $7 \%$ omitted to answer marital status. Of these respondents, $57 \%$ were graduate students and $4 \%$ were faculty members of West Virginia University (WVU). The rest of the $32 \%$ were staff and administrators of WVU or relatives of international students, while $7 \%$ did not declare their occupation. The highest income group had a monthly income that range between $\$ 1,250-3,500$ USD 
(45\%). This was followed by the income group with less than $\$ 1,250$ USD per month (31\%). Of the total respondents, only $16 \%$ owned a house, $16 \%$ reported wood experience, and $45 \%$ have been involved in the purchase of household furniture in the last five years. The educational level of the total respondents was high, with 64\% professionals (with bachelor, master and doctorate degrees). Only $32 \%$ were undergraduates and $4 \%$ opted not to declare their educational level. A majority of the respondents from the international community were from the engineering field (63\%). This was followed by $28 \%$ from humanities, physical sciences and business. The rest of the respondents' disciplines were: forestry (4\%), marketing (2\%), psychology (1\%), designs and architecture (1\%). One percent of the respondents did not declare their major.

\subsubsection{Preferences on wooden species, attributes and glaze on finish}

\section{a. Over-all preference on wooden species}

Only $59 \%$ of the total respondents $(\mathrm{N}=205)$ were able to completely rank the seven species using the 1 to 7 point Likert Scale (with 1 = "Most liked", 7 = "Least liked"). Only information derived from the completed rankings were considered when evaluating the level of consumers' acceptance of wood species. The non-response was likely a function of: the barriers in communication as the survey was written in English, unfamiliarity with the local name counterparts of the American hardwoods, time constraints in answering the survey, and lack of interest on the subject matter.

The following species were reported as the top three based on overall preference: walnut $(36 \%)$, red oak (16\%), and hickory (13\%). These species had the highest frequencies of a number 1 ranking (Figure 2.6). The preferences between walnut and red oak were statistically significant $(p$-value $=0.0002)$. On the other hand, there was no statistical significant difference on the preferences between red oak and hickory ( $p$-value $=0.05835$ ). In this study, it was noted that hickory (30\%) gained the highest frequency of being chosen in the ranking of number 2 , among any other species. 


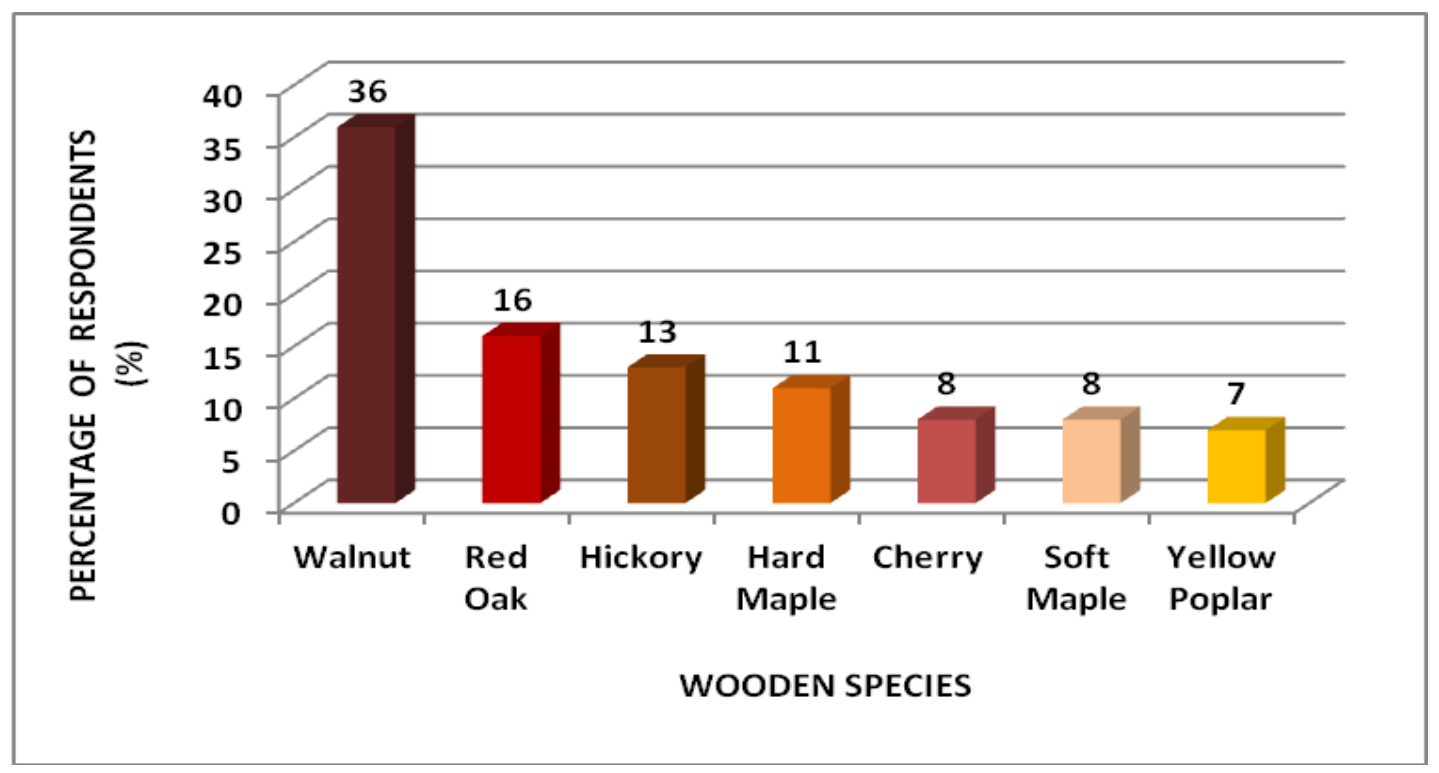

Figure 2.6. Over-all preference on wood species of the international respondents.

\section{b.Wood attributes}

Of the total respondents, $38-44 \%$ completed the ranking of 1 to 3 per wooden species attributes. Table 2.1, shows the top choice wooden species based on ranking per attribute. Among all species that made to the top 1 list, walnut was the most chosen in all of the categories. It is interesting to note that among the under-utilized species, hickory was the most preferred. Given an overall higher preference, hickory may be a very good alternative species. This species was also considered durable, expensive, elegant, with formal look and modern. However, hickory was never perceived as providing a calming effect or being sustainable by the international community. Similar to the past studies of Bowe and Bumgardner (2004), it was noted that dark color wooden samples (walnut \& hickory) used in the survey were perceived to be more expensive. On the other hand, light color wooden samples (yellow-poplar, hard maple and soft maple) were generally perceived to have a more calming effect and were viewed more eco-friendly/sustainable species. 
Table 2.1. Top choice wooden species based on ranking per attribute.

\begin{tabular}{|c|c|c|c|c|}
\hline \multirow[b]{2}{*}{ Attributes } & \multicolumn{3}{|c|}{ Top Rank Choices (\%) } & \multirow{2}{*}{$\begin{array}{c}\% \\
\text { Respondents } \\
\mathrm{N}=205 \\
\end{array}$} \\
\hline & $\# 1$ & \#2 & \#3 & \\
\hline Durability & $\begin{array}{c}\text { Walnut (42) } \\
\text { Soft Maple (14) } \\
\text { Hickory (13) } \\
\end{array}$ & $\begin{array}{c}\text { Hickory (35) } \\
\text { Walnut (20) } \\
\text { S. Maple \& Cherry (11) }\end{array}$ & $\begin{array}{c}\text { Red Oak (24) } \\
\text { Hickory (20) } \\
\text { Soft Maple (15) } \\
\end{array}$ & 44 \\
\hline Expensive & $\begin{array}{l}\text { Walnut (43) } \\
\text { Hickory (16) } \\
\text { Cherry (11) } \\
\end{array}$ & $\begin{array}{l}\text { Hickory (30) } \\
\text { Cherry (19) } \\
\text { Red Oak (16) } \\
\end{array}$ & $\begin{array}{c}\text { Red Oak (21) } \\
\text { Hickory (16) } \\
\text { S. Maple \& Cherry(15) }\end{array}$ & 44 \\
\hline Elegant & $\begin{array}{l}\text { Walnut (31) } \\
\text { Hickory (14) } \\
\text { Red Oak (13) }\end{array}$ & $\begin{array}{c}\text { Hickory (22) } \\
\text { Cherry (19) } \\
\text { R. Oak \& H. Maple (14) } \\
\end{array}$ & $\begin{array}{c}\text { Hickory (19) } \\
\text { Hard Maple (17) } \\
\text { Soft Maple (16) }\end{array}$ & 43 \\
\hline Formal Look & $\begin{array}{c}\text { Walnut (34) } \\
\text { Hickory (15) } \\
\text { R. Oak \& H. Maple(14) }\end{array}$ & $\begin{array}{c}\text { Hickory (32) } \\
\text { Hard Maple (16) } \\
\text { Walnut (13) }\end{array}$ & $\begin{array}{c}\text { Soft Maple (23) } \\
\text { Red Oak (20) } \\
\text { Hickory \& Cherry (15) }\end{array}$ & 42 \\
\hline Modern Style & $\begin{array}{l}\text { Walnut (17) } \\
\text { Hickory (16) } \\
\text { Red Oak (15) } \\
\end{array}$ & $\begin{array}{c}\text { Hickory (25) } \\
\text { Hard Maple (23) } \\
\text { Yellow-poplar (18) }\end{array}$ & $\begin{array}{c}\text { Soft Maple (19) } \\
\text { Yellow-poplar (19) } \\
\text { Cherry (17) }\end{array}$ & 41 \\
\hline $\begin{array}{l}\text { Calming } \\
\text { Effect }\end{array}$ & $\begin{array}{l}\text { Walnut (23) } \\
\text { Yellow-poplar (19) } \\
\text { Hard Maple (15) }\end{array}$ & $\begin{array}{c}\text { Hickory (25) } \\
\text { Hard Maple (20) } \\
\text { Yellow-poplar (15) }\end{array}$ & $\begin{array}{l}\text { Soft Maple (25) } \\
\text { Hickory (16) } \\
\text { Hard Maple (15) }\end{array}$ & 38 \\
\hline $\begin{array}{l}\text { Eco-friendly/ } \\
\text { Sustainable }\end{array}$ & $\begin{array}{c}\text { Walnut (25) } \\
\text { Soft Maple (16.2) } \\
\text { Yellow-poplar(16.0) }\end{array}$ & $\begin{array}{c}\text { Hard Maple (19) } \\
\text { Soft Maple (18) } \\
\text { Hickory (16) }\end{array}$ & $\begin{array}{c}\text { Hickory (18) } \\
\text { Hard Maple (16) } \\
\text { Soft Maple (16) }\end{array}$ & 39 \\
\hline
\end{tabular}

\section{c. Glaze preference: Glossy vs. Matte}

Figure 2.7 shows the results of the respondent's preference between glossy and matte finish on a hickory sample. Results indicated that there was no statistically significant difference in the international community's $(54 \%$ of 170 respondents) preference between glossy and matte finish ( $p$-value $=0.1931)$. For purposes of looking at differences between countries, only China, India and Kingdom of Saudi Arabia (KSA) were considered in this study because the remainder of the countries had a small population $(n<20)$. 


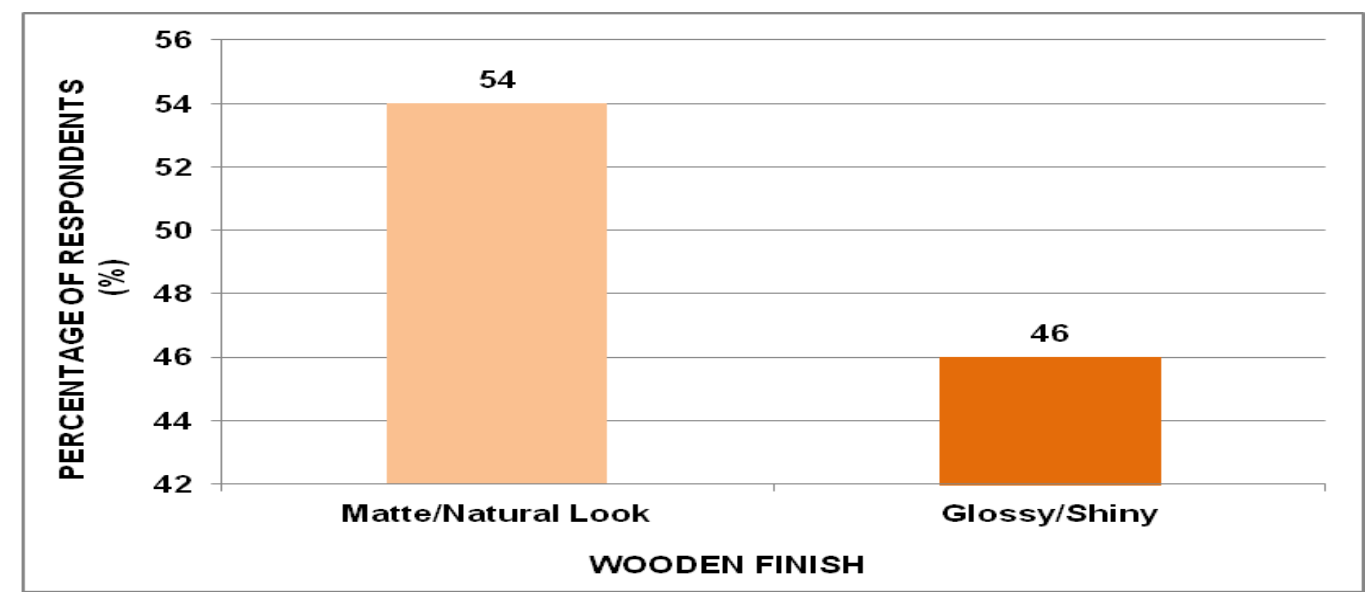

Figure 2.7 Over-all Preference on the glaze of the wood finish.

In relation to Chinese (58\%) and Arabian (52\%) respondents, there was no statistically significant difference in their preference between matte and glossy finish (Table 2.2). On the other hand, Indian respondents (73\%) preferred the glossy over the matte finish. Based from these results, wood finish preferences should be carefully studied on a per country basis than per region as differences may possibly occur.

Table 2.2 Wood finish preferences of countries with $n>20$ : China, India and KSA.

\begin{tabular}{|c|c|c|c|c|}
\hline & $\begin{array}{c}\text { Total } \\
\text { Respondents } \\
\mathrm{N}=170\end{array}$ & Glossy & Matte & p-value \\
\hline Country & $18 \%$ & $42 \%$ & $58 \%$ & 0.2041 \\
China & $13 \%$ & $73 \%$ & $27 \%$ & $0.0003^{*}$ \\
India & $14 \%$ & $48 \%$ & $52 \%$ & 0.7681 \\
\hline
\end{tabular}

* indicates a statistically significant difference at alpha level $=0.05$.

\subsubsection{Preferences based on demographics and socio - economic profile}

Respondents were asked to rank all seven species based on overall preference ( $1=$ Most preferred, $7=$ Least preferred). For each species, a success was considered as the respondents ranking that species with a number 1 , while all other rankings (2-7) were considered as failures. Results from twoproportion (z-test) analysis indicated that there was a statistically significant difference in the preference for walnut between males and females (Table 2.3). 
For all other species there was no statistically significant difference in overall preference based on gender.

Table 2.3 Gender preference on wooden species most ranked number 1.

\begin{tabular}{|c|c|c|c|}
\hline \multirow{2}{*}{ Species } & \multicolumn{2}{|c|}{ Number of Successes } & \multirow{2}{*}{ p-value } \\
\cline { 2 - 3 } & Female & Male & 0.8864 \\
Cherry & 3 & 7 & 0.9188 \\
Hickory & 4 & 9 & 0.2975 \\
Soft Maple & 1 & 6 & 0.2977 \\
Hard Maple & 2 & 9 & 0.5125 \\
Red Oak & 4 & 12 & $0.0220^{\star}$ \\
Walnut & 17 & 20 & 0.4063 \\
Yellow-poplar & 1 & 5 & \\
TOTAL & 32 & 68 & \\
\hline
\end{tabular}

* indicates a statistically significant difference at alpha level $=0.05$.

Further analysis was performed in relation to comparing walnut and red oak overall preference by age group (Table 2.4). Results indicated that the only statistically significant difference $(p$-value $=0.0499)$ in overall preference for walnut versus red oak was that for the 24-29 and $\geq 30$ year old categories. However, it was noted that the significance was extremely close to the 0.05 significance alpha level. Overall, there was no clear overall preference for either red oak or walnut between age groups.

Table 2.4 Preferences for walnut and red oak in each age category.

\begin{tabular}{|c|c|c|}
\hline \multirow{2}{*}{$\begin{array}{c}\text { Age Group Comparisons } \\
\text { (years old) }\end{array}$} & \multicolumn{2}{|c|}{ W-values } \\
\cline { 2 - 3 } $18-23$ vs. $24-29$ & 0.5856 & Red Oak \\
$24-29$ vs. $\geq 30$ & 0.6740 & 0.5433 \\
$18-23$ vs. $\geq 30$ & 0.9644 & 0.1253 \\
\hline
\end{tabular}

* indicates a statistically significant difference at alpha level $=0.05$.

In this study, respondents of age 30 years and older, was further analyzed as they usually have high purchasing power due to higher income. Their preference for walnut was statistically significant among all species, except for soft maple and hard maple (Table 2.5). Results indicated that there 
was no statistically significant evidence that under-utilized species (soft maple, hard maple, hickory and yellow poplar) were more preferred than commercialized species (red oak and cherry). Therefore, the market acceptability of under-utilized species within age group $\geq 30$ years old was still undetermined and requires further investigation.

Table 2.5 Preferences on commercial species on age group $\geq 30$ years old.

\begin{tabular}{|c|ccc|}
\hline \multirow{2}{*}{ Species } & \multicolumn{3}{|c|}{ Age Group $>30$ years old $(p$-value) } \\
\cline { 2 - 4 } & Red Oak & Cherry & Walnut \\
\hline Cherry & 0.5520 & - & $0.0175^{*}$ \\
Hickory & 0.2144 & 0.6381 & $0.0483^{*}$ \\
Soft Maple & 0.1582 & 0.3853 & 0.1093 \\
Hard Maple & 0.1582 & 0.3853 & 0.1093 \\
Red Oak & - & 0.5520 & $0.0049^{*}$ \\
Walnut & $0.0049^{*}$ & $0.0175^{*}$ & - \\
Yellow-poplar & 0.2980 & 0.6381 & $0.0483^{*}$ \\
\hline
\end{tabular}

* indicates a statistically significant difference at alpha level $=0.05$.

Figure 2.8, shows how the respondents in each age group ranked their most preferred species. Further analysis was conducted to look at walnut and red oak in comparison to age group. The results indicated that there was a statistically significant difference between red oak and walnut in every age categories: $\quad 18-23 \quad(p$-value $=0.0489) ; \quad 24-29 \quad$ (p-value $=0.0454) ; \quad \geq 30$ ( $p$-value $=0.0225)$. 


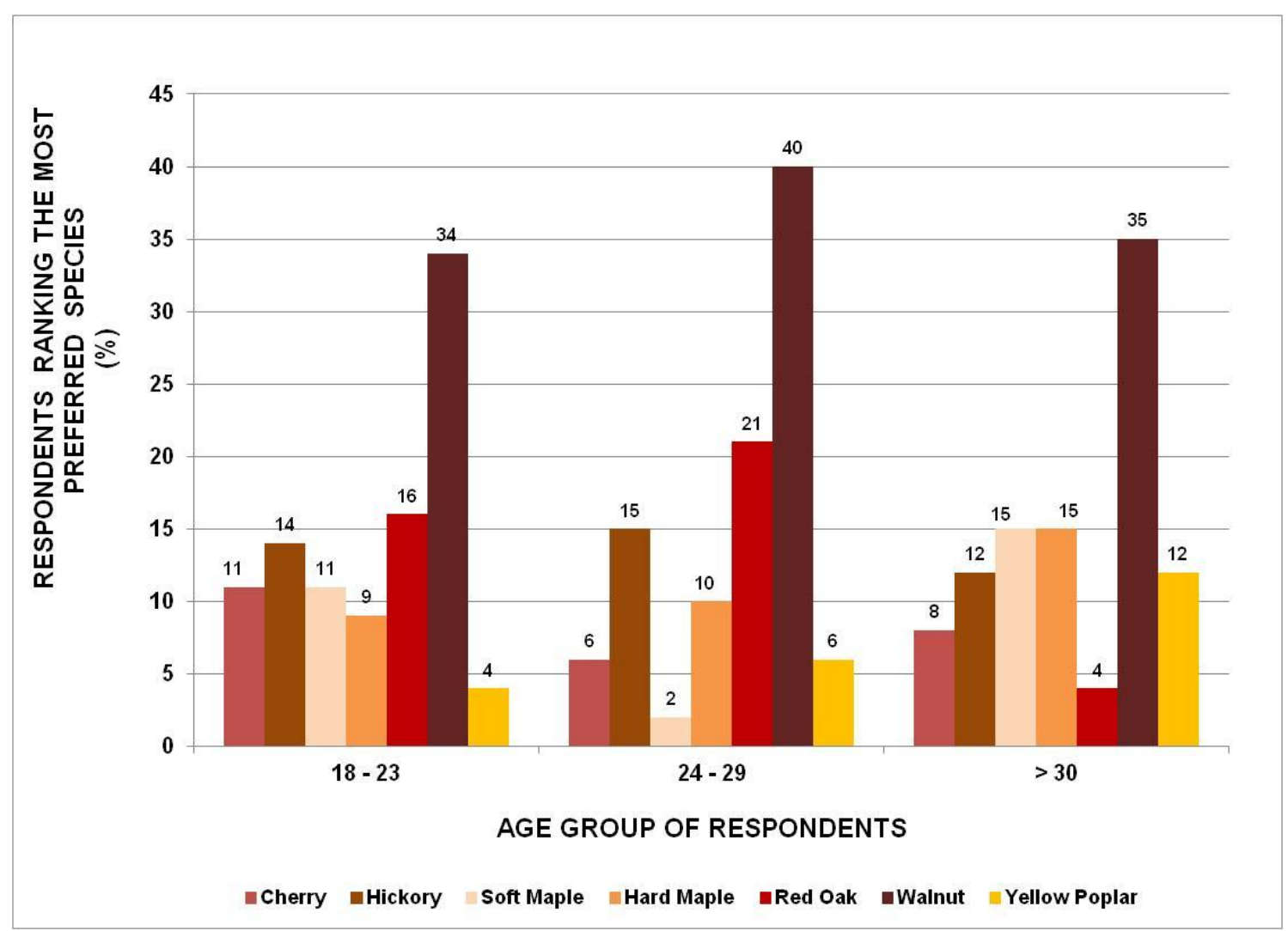

Figure 2.8 Percentage ranking of the most preferred species based on age.

\subsubsection{Wood Identification and Finish Recognition}

Determining consumer's perceptions and preferences are necessary initial steps to highlight the expanded market potentials of these under-utilized hardwood species. According to Blomgren (1965), wood has intriguing characteristics on its color, smell and look, which people can psychologically relate to and even associate memories. Qualitative observations were also provided in this study (see Appendix 1.5). Out of 118 respondents, 33\% thought that cherry was red oak. While not tested, this misidentification could have been related to respondents' association with color of the wood species to the common name. Yellow-poplar for instance, was well identified (54\%) compared with the rest of the species perhaps due to distinguishing yellowish color (Table 2.6). It was also noted that walnut was misidentified with red oak in a fairly high proportion (31\%). Among the respondents, red oak (14\%) and hickory (17\%) were the two least identifiable species. These results suggest that more 
familiarization with Appalachian hardwoods species (in particular red oak and hickory) or their common name is recommended when marketing to international communities within the U.S.

Table 2.6 Wooden species identification with their most misidentified counterparts by percentage.

\begin{tabular}{|cccc|}
\hline & & & \\
\hline & Percent of Respondents & \multicolumn{2}{c|}{$\begin{array}{c}\text { Species Most } \\
\text { Incorrectly Identified With } \\
\text { (\% of Respondents) }\end{array}$} \\
\hline Actual Species & Correctly Identifying (\%) & Red Oak & $(33)$ \\
Cherry & 25 & Hard Maple & $(23)$ \\
Hickory & 17 & Hickory & $(25)$ \\
Soft Maple & 21 & Soft Maple & $(25)$ \\
Hard Maple & 26 & Hickory & $(21)$ \\
Red Oak & 14 & Red Oak & $(31)$ \\
Walnut & 27 & Soft Maple & $(14)$ \\
Yellow-poplar & 55 & \multicolumn{3}{|}{} \\
\hline
\end{tabular}

The use of wood finishing techniques has been a practice in Asian countries to make tropical species look like the U.S. commercial hardwood species (Bowe and Bumgardner, 2004). The recognition of wood species was investigated to check whether respondents from 49 nations can determine wood of different species with similar wood finish. However, out of 180 respondents, only China ( $n=30)$, India $(n=24)$ and Kingdom of Saudi Arabia $(n=28)$ can be considered in this study due to sample size restrictions $(n>20)$. It should be noted that the hickory wooden sample used was not multi-colored (only heartwood) and therefore the results found really only pertain to hickory with a high percentage of heartwood. Most of the respondents significantly recognized the differences in wooden samples, except for hickory (in spice finish) and red oak (with honey spray) at $p$-value $=0.0000$. Respondents $(63 \%)$, thought the two wooden samples were of similar species because of the finish applied (Figure 2.9). Moreover, the absence of sapwood to the hickory wooden sample gave no color variations typical to hickory species. This indicated that investments on lumber sorting and wood finishing techniques could help assist hickory in being 
an alternative material for markets where red oak is important. Respondents from China $(60 \%)$, India (67\%) and KSA (71\%) were not able to recognize the difference between red oak (with honey spray) and hickory (in spice finish). However, these observations were only statistically significant for India $(p$-value $=0.0209)$ and KSA ( $p$-value $=0.0013)$, but not for China ( $p$-value $=0.1213)$.

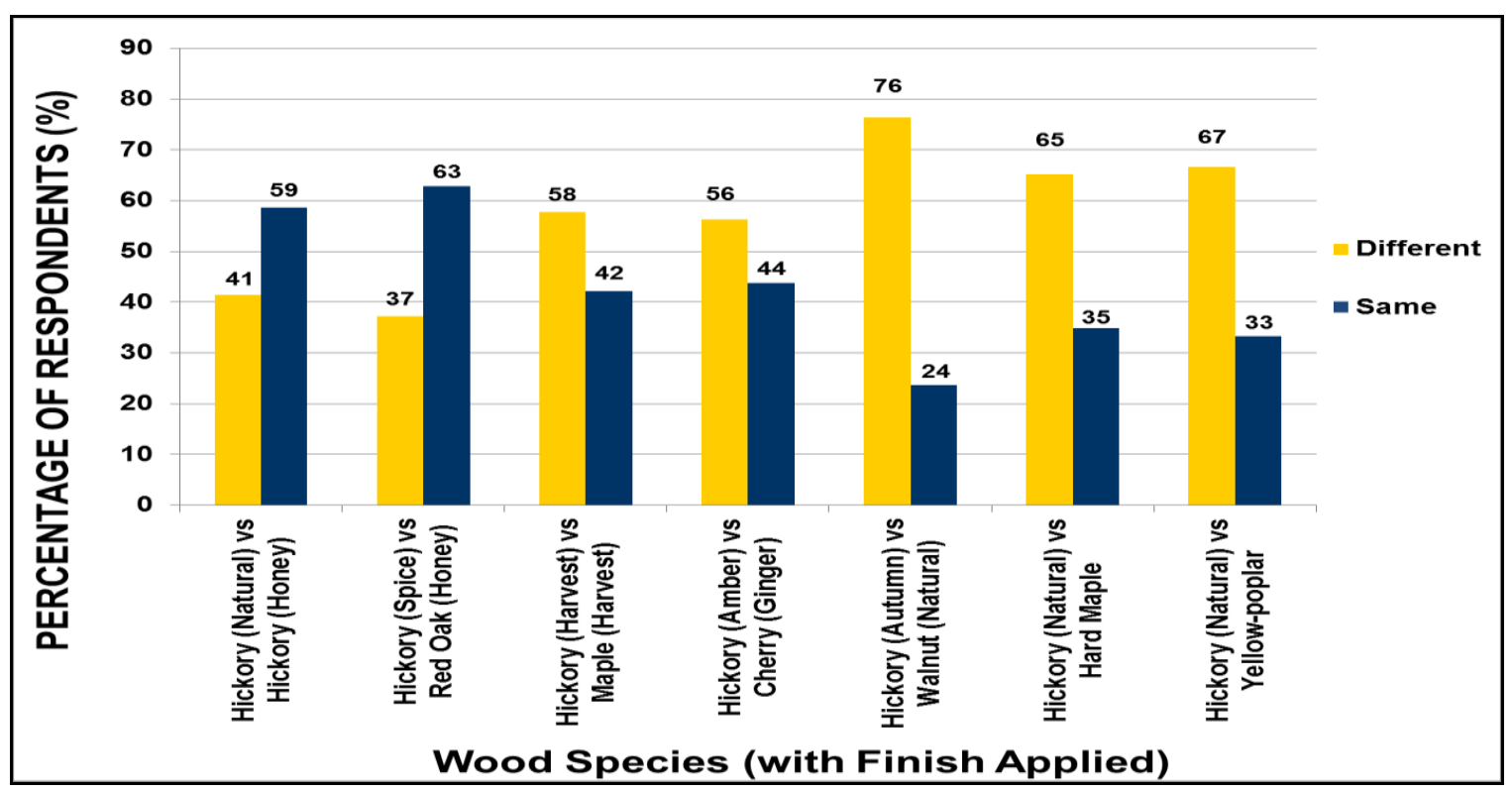

Figure 2.9 Identification of species with various applied stains.

\subsubsection{Species Determination and Levels of Expertise}

The ability of the respondents to determine wooden species was examined based on: wood experience, major or field of discipline, and purchase decision involvement. However, in this study, $84 \%$ of the total respondents had no experience in working with wood products. Similarly, $51 \%$ were never involved in the purchase of furniture during the last five years. Wood experience is assumed to be an important contributing factor in the purchasing decision of household wooden products. Results showed no statistically significant differences in the identification of species based on the level of wood working experience (Table 2.7). 
Table 2.7 Species determination based on the level of woodworking experience.

\begin{tabular}{|c|c|}
\hline Species & $\begin{array}{c}\text { With VS Without } \\
\text { Wood Experience } \\
\text { p-values }\end{array}$ \\
\hline Cherry & 0.5531 \\
Hickory & 0.3547 \\
Soft Maple & 0.1024 \\
Hard Maple & 0.3439 \\
Red Oak & 0.8498 \\
Walnut & 0.0518 \\
Yellow-poplar & 0.3095 \\
\hline
\end{tabular}

In most cases, a higher percentage of respondents with wood working experience were more able to identify the wooden samples except for hickory (Figure 2.10). However, there was no statistically significant evidence that respondents with wood working experience can better identify hickory ( $p$-value $=0.3547$ ) than those without. This result suggests that the level of experience in wood working was not the sole factor that results in the international community respondent's ability to easily identify hickory.

It is interesting to know that yellow-poplar had the highest percentage of being correctly identified among the respondents with woodworking experience (65\%). This identification of yellow-poplar showed a significant difference to redoak ( $p$-value $=0.0012)$; cherry ( $p$-value $=0.0267$ ), and hickory ( $p$-value $=0.0003$ ). Some reasons of the Yellow-poplar's easy identification could either be due to the distinguishing yellowish color or the respondents' familiarity with the species because of its abundance in the Appalachian region. 


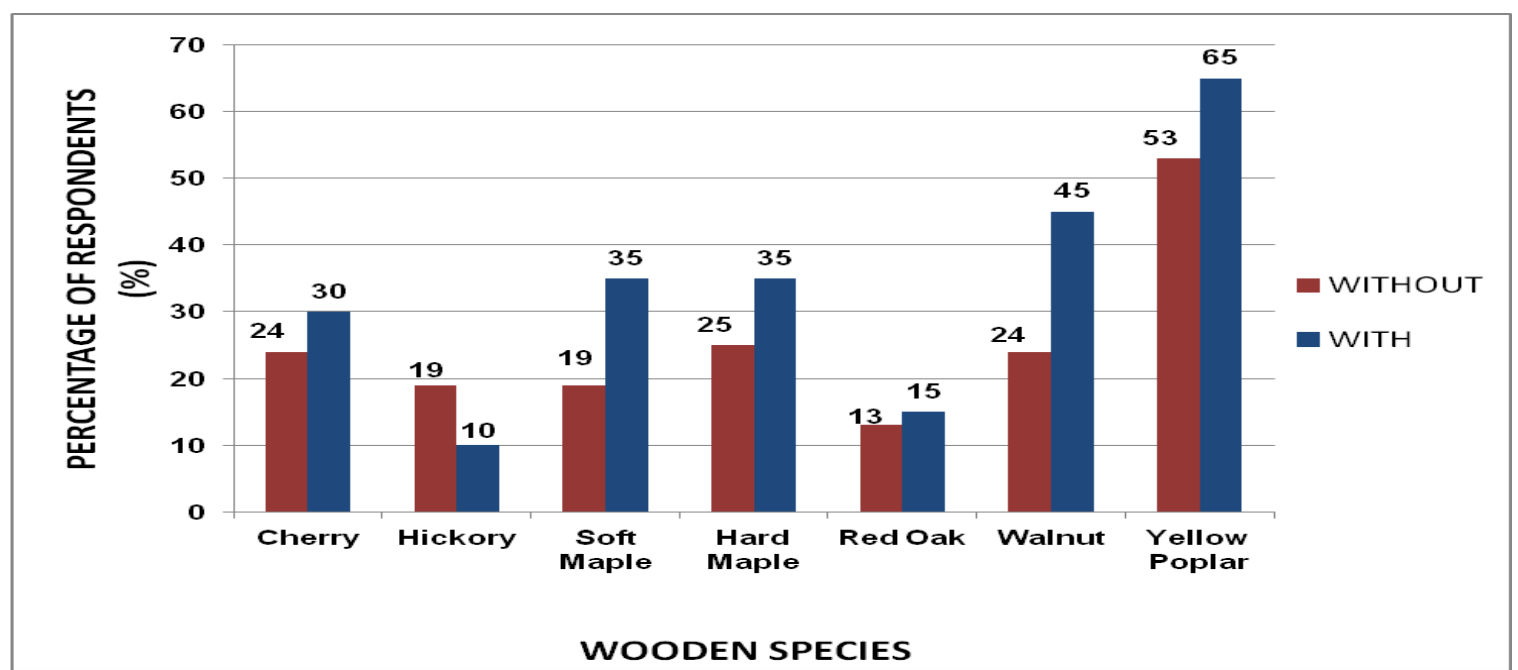

Figure 2.10 Species correctly identified based on the levels of experience in working with wood.

Successfully marketing under-utilized hardwoods requires providing the necessary background and information that end-use consumers need. Engineers for instance, are responsible in the selection and approval of building and construction materials, while the design groups are for the innovations and sustainable product development of a certain wooden product. Each of these groups may have a different ability to identify wood species. Analysis was conducted to investigate how respondents from different fields of study were able to identify wood species. Comparison was only focused on Engineering (63\%) and Other Major (28\%) respondents. In this paper, conclusions cannot be drawn from other disciplines (Forestry, Marketing, Psychology, Architecture and Designs) due to their small sample sizes.

Results showed that there was a statistically significant difference in the identification of yellow-poplar with the rest of the wooden species (Table 2.8). This suggests that both the Engineering and Other Major (i.e. humanities, physical sciences and business) did not possess enough knowledge to correctly identify all of the wood species, except for yellow-poplar. However, there was no significant difference in the ability of the engineering and other major in the identification of all other species. It was interesting to note that the Engineering major had a hard time identifying more commercially available hardwoods such as walnut (28\%), cherry (21\%), and red oak (12\%). 
Table 2.8 The level of significance in the identification of yellow-poplar with other species based on the discipline of respondents.

\begin{tabular}{|ccc|}
\hline $\begin{array}{c}\text { Yellow-poplar } \\
\text { vs. } \\
\text { Other Species }\end{array}$ & \multicolumn{2}{c|}{ p-values } \\
\hline Cherry & $0.0001^{*}$ & $0.0439^{*}$ \\
Hickory & $0.0000^{*}$ & $0.0006^{*}$ \\
Soft Maple & $0.0000^{*}$ & $0.0045^{*}$ \\
Hard Maple & $0.0131^{*}$ & $0.0045^{*}$ \\
Red Oak & $0.0000^{*}$ & $0.0006^{*}$ \\
Walnut & $0.0027^{*}$ & $0.0045^{*}$ \\
Yellow Poplar & - & - \\
\hline
\end{tabular}

* indicates a statistically significant difference at alpha level $=0.05$.

Purchasing involvement of furniture products within the last five years was used to evaluate the respondent's ability to identify wood (Figure 2.11) if they have been actively buying wood materials. In general, the most identified species based on purchase involvement of furniture during the last five years were yellow-poplar (60\%), walnut (30\%) and hard maple (28\%). Familiarity with these species could be attributed to the use of these hardwoods for manufacturing furniture.

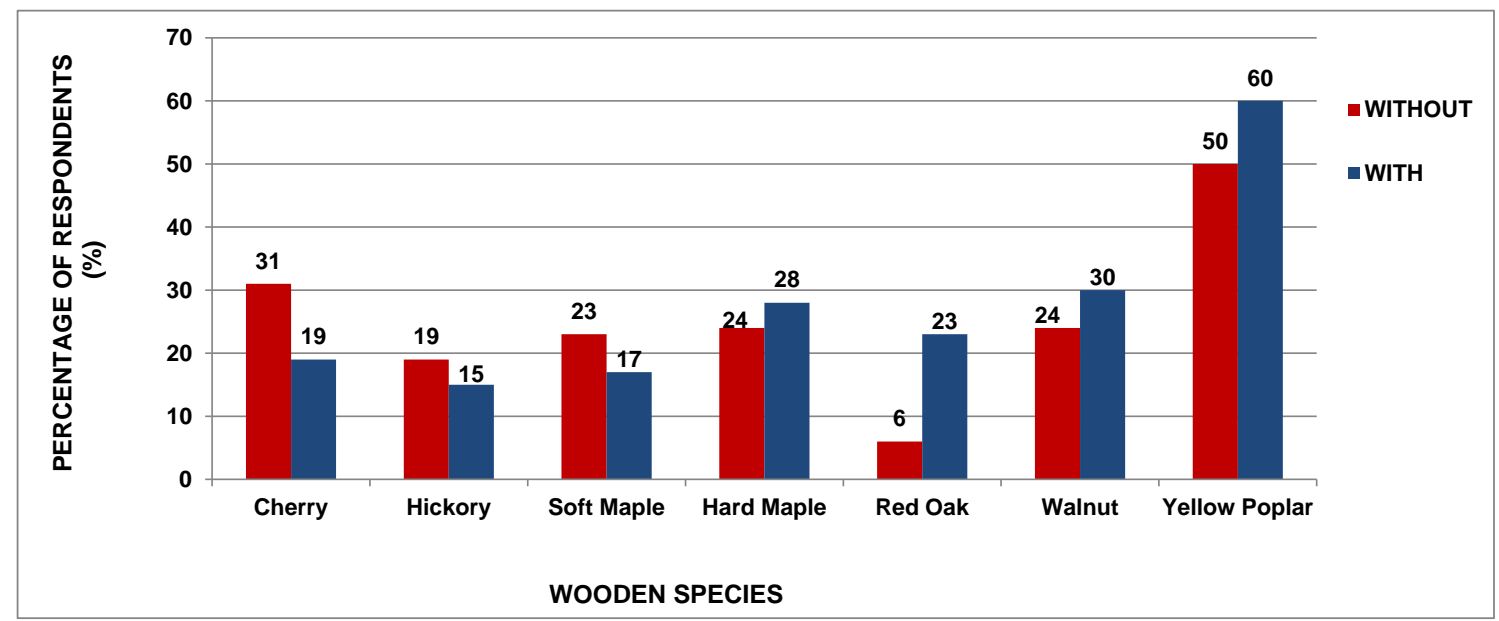

Figure 2.11 Species correctly determined based on the past experience in purchasing furniture. 
Overall, yellow-poplar was the most identified hardwood species. It was noted that the respondents with past purchasing experience were more able to identify yellow-poplar, walnut, red oak, and hard maple than those with no past experience. However, results indicated that there was no statistically significance difference in the species determination based on purchase involvement, except for red oak (Table 2.9).

Table 2.9 The level of significance in the correct identification of species based on past experience in purchasing furniture within the last five years.

\begin{tabular}{|cc|}
\hline Species & $\begin{array}{c}\text { With VS Without } \\
\text { Purchase Involvement } \\
\text { p-values }\end{array}$ \\
\hline Cherry & 0.1471 \\
Hickory & 0.6011 \\
Soft Maple & 0.4543 \\
Hard Maple & 0.6170 \\
Red Oak & $0.0124^{*}$ \\
Walnut & 0.4702 \\
Yellow Poplar & 0.2650 \\
\hline *indicates a statistically significant difference at alpha level $=0.05$.
\end{tabular}

\subsubsection{Major hardwood products demand projections out of hickory wood}

Analysis was performed to determine what type of wood products that the international community respondents would consider purchasing if they were made from hickory. The top three choices (Figure 2.12) for considering purchasing products made from hickory were: doors (75\%), kitchen cabinets (74\%) and wardrobe cabinets (67\%). This information could help secondary wood manufacturers to develop innovative designs on hardwood products where there is market acceptability for hickory wood. 


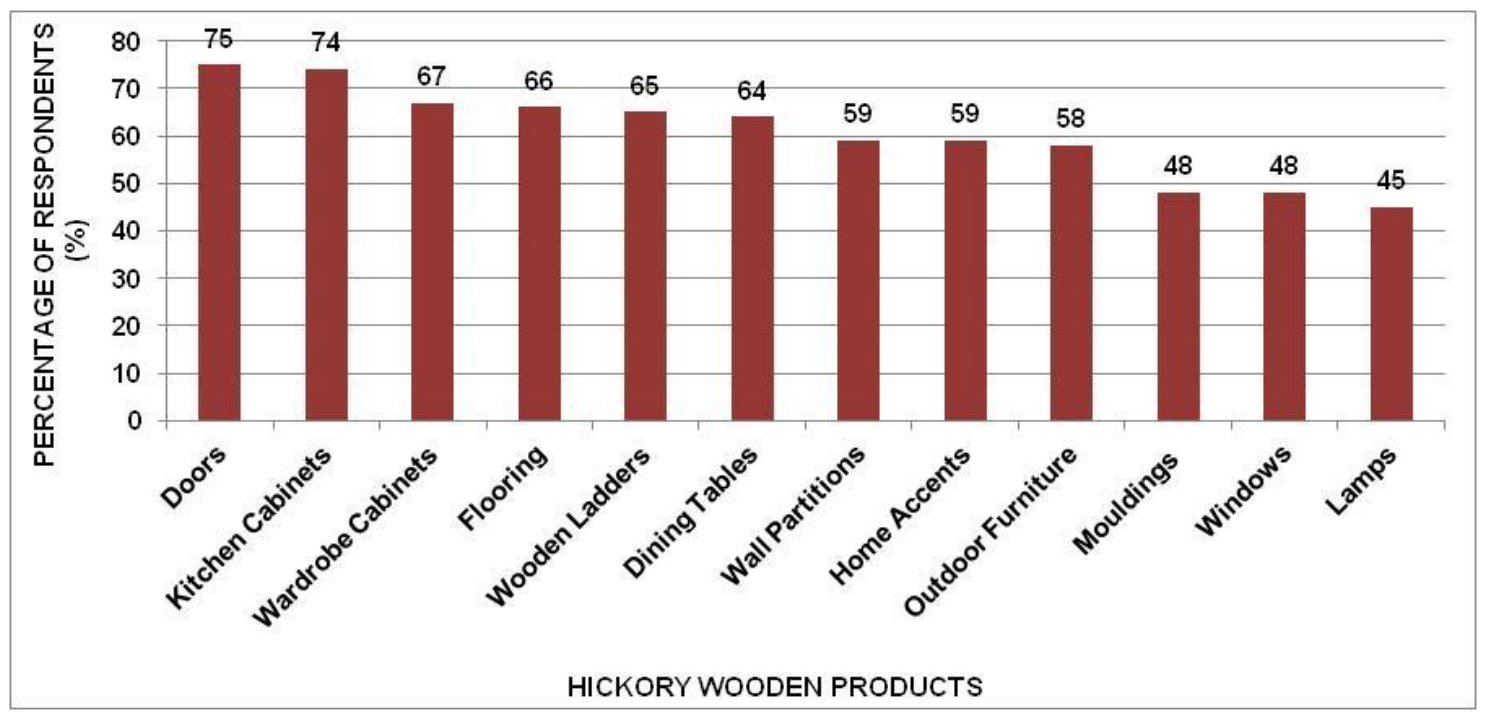

Figure 2.12 Hardwood products that respondents would consider purchasing if made from hickory.

\subsubsection{Factors in wood purchasing decisions}

Respondents were asked to provide their level of concern for a variety of different factors that influence their wood purchasing decisions. Level of concern for each factor was assigned values based on a 5 point Likert Scale ( $1=$ "Of no concern", 2= "Of little concern", 3= "Of moderate concern", 4= "Of greater concern", and $5=$ "Of greatest concern"). The average response values were used to rank the factors that influenced the respondents on purchasing decisions (Figure 2.13). Based on the respondents, functionality/safety (mean=3.95) was the most influential factor that influenced purchasing decisions. However, it was apparent that wood finish (mean=3.80) and color (mean=3.79) were on average, very important. 


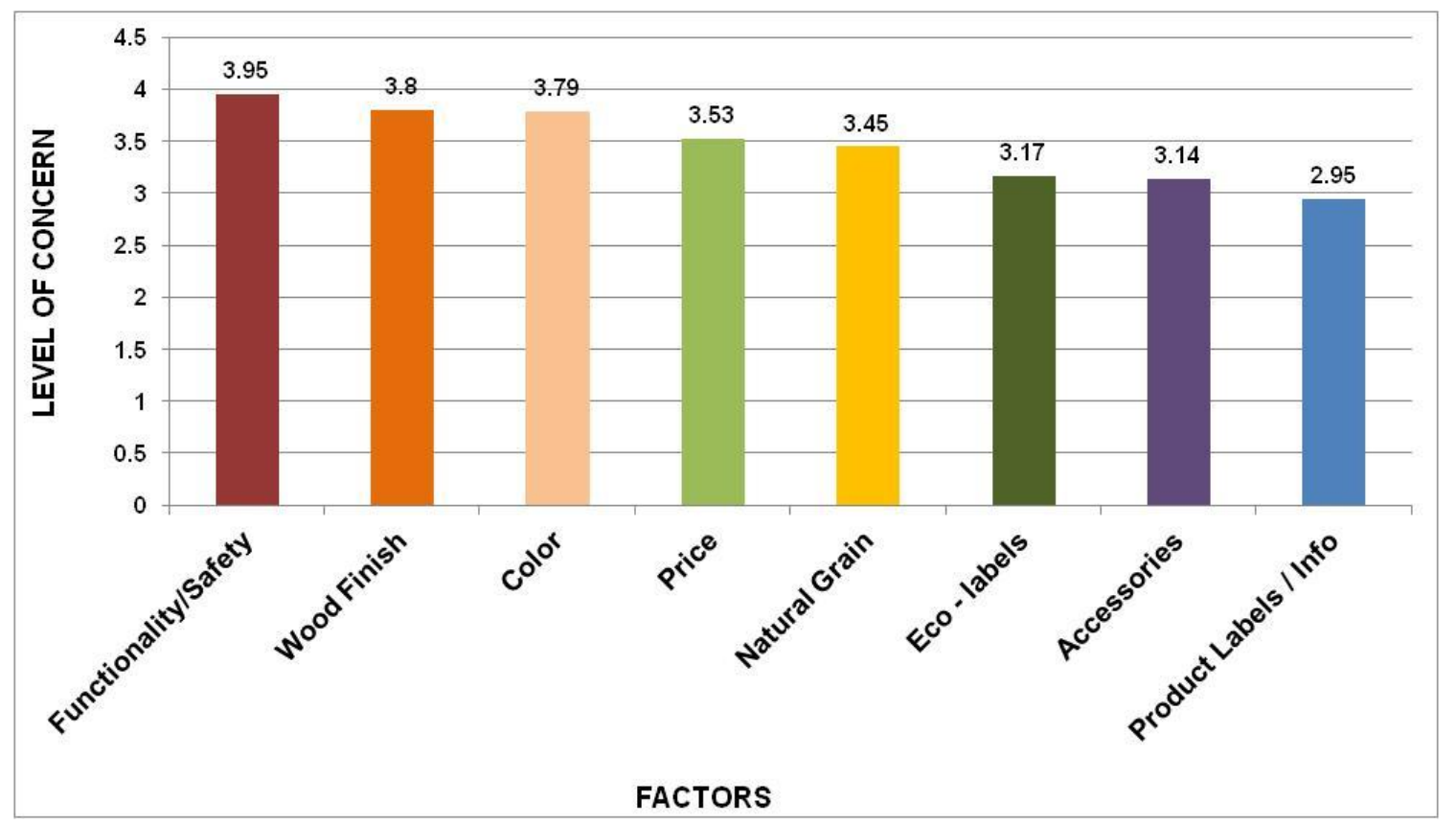

Figure 2.13 Factors that influenced the respondents in wood purchasing decisions.

The analysis of medians was used to further investigate differences in the median level of concern for each factor when purchasing wood products. In this study, the T-Test (test of two samples) procedure was performed using the Nonparametric (Mann-Whitney) test. Table 2.10, shows the factors which were statistically significant in the wood purchasing decision factors of the international community. Results from this analysis showed differences between the median levels of concern between the various factors. Functionality/safety was based on the median more of a concern, as it was statistically different from the median level of concern for wood finish.

These results suggest that functionality/safety and wood finish are not of equal concern for the respondents when purchasing wood products. It was interesting to note, that when buying wood products, the respondents considered functionality/safety and color more statistically significant concern than price. This finding suggests that international community when purchasing wood products are looking for value-added, multi-functional wood products regardless of price. This result supported the past research of Blomgren (1965) where household 
wood products were usually purchased because of its use, thus advertisers should capitalize more on item functionality than on the wood material itself. In terms of least concerning purchasing decision factors, product labels/information was on average of least concern for the respondents. However, the difference in average level of concern for accessories and eco-labels was not statistically significant when comparing them to product labels/information. These results suggest that foreign nationalities in the domestic market are least concerned over product labels, accessories, and eco-labels when looking to purchase wood products.

Table 2.10 Nonparametric (Mann-Whitney) test results for level of concern related to purchase decision factors of the international community.

\begin{tabular}{|ccc|}
\hline Factors & Alternative & $\begin{array}{c}\text { T-test: Two Sample } \\
\text { Non - parametric } \\
\text { (Mann - Whitney ) Test } \\
\text { p-value }\end{array}$ \\
\hline $\begin{array}{c}\text { Functionality/Safety vs. } \\
\text { Wood Finish }\end{array}$ & Diff $<>0$ & $0.031639^{*}$ \\
Wood Finish vs. Color & Diff $<>0$ & 0.996391 \\
Color vs. Price & Diff $<>0$ & $0.011315^{*}$ \\
Functionality/Safety vs. & & $0.000047^{*}$ \\
\hline Price & Diff $<>0$ & \\
\hline
\end{tabular}

*indicates a statistically significant difference at alpha level $=0.05$.

\subsubsection{Sustainable product designs and concepts on hickory furniture}

The rustic look of hickory furniture was evaluated to determine whether or not this design style has market acceptability among the international community in the domestic market. Specifically, perceptions on furniture with tree bark designs were investigated. Out of 189 respondents, $41 \%$ answered MAYBE and 25\% LIKELY in relation to investing in these types of furniture. The designs were considered sustainable (55\%) but were considered old-fashioned $(66 \%)$. Results showed that the perceptions on hickory furniture products with tree bark remaining were significantly sustainable ( $p$-value $=0.0482$ ), and old fashioned ( $p$-value=0.0000). Table 2.11, further shows that the international 
community significantly considered investing ( $p$-value $=0.0007$ ) on these types of furniture designs.

Table 2.11 Perceptions on hickory furniture products with tree bark remaining.

\begin{tabular}{|c|c|c|c|}
\hline Perceptions & $\mathrm{n}$ & $\%$ & $\mathrm{p}$-value \\
\hline Will consider investing ${ }^{a}$ & 189 & & \\
\hline Not at all & & 12 & $0.0000^{*}$ \\
\hline Unlikely & & 12 & $0.0000^{*}$ \\
\hline Maybe & & 41 & $0.0007^{*}$ \\
\hline Likely & & 25 & $0.0007^{*}$ \\
\hline Very Likely & & 10 & $0.0000^{*}$ \\
\hline & 185 & & $0.0482 *$ \\
\hline Sustainable & & 55 & \\
\hline Depleting & & 45 & \\
\hline & 182 & & $0.0000^{*}$ \\
\hline Modern & & 34 & \\
\hline Old - fashioned & & 66 & \\
\hline
\end{tabular}

*indicates a statistically significant difference at alpha level $=0.05$.

a. Comparison of MAYBE to other responses.

Promotional messages on how to position household wooden products are important to expand market opportunities. Furniture with the tree bark remaining may be related to a "going back to nature trend", as these can be viewed as more sustainable. The respondents indicated that leaving on the tree bark made the wood products more sustainable. Given this, manufacturers should consider producing furniture with bark and other rustic characteristics when targeting more niche markets that are highly related to sustainability. Stream lining of products to increase the share of a niche market may result in improved market share for low-valued hardwoods.

\subsubsection{Emotional advertisements vs. technical information on promotional messages}

Information dissemination is vital in marketing new wood products and species to manufacturers and buyers (Bowe and Bumgardner, 2002). Promotional campaign efforts on species' properties are important both for market approval and acceptability. Table 2.12 shows the impacts of the 
promotional ads used to position hickory wooden products. The developed emotional advertisement was not enough to give an impression that hickory wooden products were durable. Most of the respondents were still NOT SURE $(52 \%)$ if hickory wood was the most durable among the wood samples after reading the emotional advertisement about hickory. Perhaps, foreign nationalities were not able to relate on the historical facts \& figures about the contribution of hickory wood in the early days of the U.S. However, $68 \%$ showed more interest with hickory wood and $69 \%$ were more likely to purchase hickory products after reading the emotional ads.

In comparison between the effectiveness of technical information and emotional ads, technical ads resulted in more favorable perceptions of hickory as compared to emotional ads with regards to durability ( $p$-value $=0.0000$ ). Respondents significantly answered YES (59\%) on its durability. However, there was no statistically significant evidence that technical information was more effective over the emotional ads to increase interest in hickory ( $p$-value $=0.1282$ ) and the likelihood of purchasing a hickory product $(p-$ value $=0.0575)$.

Table 2.12 Impact of promotional ads used to position hickory wood.

\begin{tabular}{|c|c|c|c|}
\hline \multirow[b]{2}{*}{ Impacts } & \multicolumn{2}{|c|}{ Promotional Ads } & \multirow[b]{2}{*}{$\mathrm{p}$-value } \\
\hline & Emotional & Technical & \\
\hline a. Durability & $n=186$ & $\mathrm{n}=187$ & \\
\hline No & $11 \%$ & $11 \%$ & \\
\hline Yes & $37 \%$ & $59 \%$ & $0.0000^{*}$ \\
\hline Not Sure & $52 \%$ & $29 \%$ & \\
\hline b. Interests on hickory wooden sample & $n=186$ & $\mathrm{n}=187$ & \\
\hline No & $32 \%$ & $28 \%$ & \\
\hline Yes & $68 \%$ & $72 \%$ & 0.1282 \\
\hline c. Likely to purchase & $n=182$ & $n=186$ & \\
\hline No & $31 \%$ & $22 \%$ & \\
\hline Yes & $69 \%$ & $78 \%$ & 0.0575 \\
\hline
\end{tabular}

*indicates a statistically significant difference at alpha level $=0.05$. 
After reading the promotional ads, respondents were further asked about their willingness to pay extra for hickory wood products. Table 2.13, shows the percentage willingness of the respondents to pay various amounts more for a product made from hickory. Table 2.13, shows the percentage willingness of the respondents to pay extra in a given conditions. In relation to hickory products, $88 \%, 94 \%$, and $80 \%$ of 188 respondents, indicated to pay extra if the product was made from hickory, had value-added features, and made in the USA, respectively. Promotional messages therefore for hickory wooden products, may include the origin of species being from the U.S. to highlight its strengths in the market.

Table 2.13 Willingness to pay extra for hickory wooden product.

\begin{tabular}{|l|c|c|c|c|c|c|}
\hline \multirow{2}{*}{\multicolumn{1}{|c|}{ CONDITIONS }} & \multicolumn{6}{|c|}{ \% Extra Respondents Were Willing to Pay } \\
\cline { 2 - 7 } & 0 & $1-4$ & $5-9$ & $10-15$ & $16-20$ & $>20$ \\
\hline if made from hickory species & 12 & 16 & 27 & 30 & 12 & 4 \\
\hline with value - added features & 6 & 21 & 23 & 31 & 13 & 6 \\
\hline if Made in the USA & 20 & 18 & 18 & 18 & 16 & 10 \\
\hline
\end{tabular}




\subsection{CONCLUSIONS}

Based on the results of the study, it was concluded that the international community in the domestic market preferred walnut, red oak and hickory as their top choice species. The preference for under-utilized species was not statistically significant. Hickory, as one of the identified under-used species was oftentimes ranked number 2 , thus could serve as an alternative species. The rest of the under-utilized species (hard maple, soft maple and yellow-poplar) were viewed as eco-friendly and sustainable. The preference for walnut was statistically significant between male and female respondents. For age group 30 years old and older, the preference for cherry, hickory, red oak and yellow-poplar were statistically significant. Generally, results showed that there was no statistically significant evidence that the level of wood working experience improved the respondent's species determination. Yellow-poplar was the most correctly identified species, perhaps due to color associations or familiarity with the species due to its abundance in the region. Cherry on the other hand, was most often mistaken as red-oak. International respondents determined most of the species even when applied with wood finish, except for hickory (with spice finish) and red oak (with honey spray). The absence of color variations on hickory wooden sample made it look closer to red oak. Advertisements can increase the interests of the international community in using more of the under-utilized species. The use of technical information was found significantly more effective than the emotional ads, with regards to relaying the durability aspects of hickory. Product designs with the tree bark remaining was significantly seen as oldfashioned and sustainable. Functionality and Safety was considered the most influential factor in the respondent's wood purchasing decisions. This finding suggests that the international community in the domestic market would likely purchase household wood products with value-added features regardless of price. Marketers can use these results to position under-utilized wooden species in this period of green economy. 


\subsection{REFERENCES}

American Hardwood.2010. Sustainable American Hardwoods, A guide to species.

Appalachian Hardwood Manufacturers Inc., Resource Guide. 2010. p. 3.

Appalachian Regional Commission.2010.Moving Appalachia Forward: Strategic Plan 2011 2016, p.25.

Barret, G., J.Baumgras, and W.Luppold. 2001. Utilization of the Eastern Hardwood Resource by the Hardwood Sawmilling Industry. Northern Journal of Applied Forestry. 18(2):3-4.

Blomgren,G.W.Jr. 1965. The Psychological Image of Wood. Forest Product Journal. 15(4):149151.

Brinberg, D., M. Bumgardner, and K. Daniloski. 2007. Understanding perceptions of wood household furniture: application of a policy capturing approach. Forest Products Journal. 57(7/8):21-26.

Bowe, S., and M. Bumgardner. 2004. Consumers perceptions and knowledge of common furniture woods. USDA Forest Service: Proceedings 14th Central Hardwood Conference. Northeast Research Station: 404 - 410.

Bowe, S., and M. Bumgardner. 2004. Species selection in secondary wood products: Perspectives from different consumers. Wood and Fiber Science. 36(3):319 - 328.

Bowe, S., and M. Bumgardner. 2002. Species selection in secondary wood products: Implications for product design and promotion. Wood and Fiber Science. 34(3): 408 418.

Buehlmann, M., M. Bumgardner, A. Schuler, and M. Barford. 2007. Assessing the impacts of global competition on the Appalachian hardwood industry. Forest Products Journal. 57(3):89-93.

Buehlmann, U., M. Bumgardner, A. Schuler, and K. Koenig. 2011. Housing and the Wood Industry, Trends and Market Conditions W \& WP. Woodworking Network.com, p.24.

Buehlmann, U., A. Schuler. 2009. The U.S. household furniture industry: Status and opportunities. Forest Products Journal. 59(9):27.

Esty,D. and A.Winston. 2009. Green to Gold. How smart companies use environmentalstrategy to innovate, create value, and build competitive advantage. pp. $15,62-64,101-303$.

Hardwood Market Reports Last Quarters. 2007 - 2010.

Hintze, J. 2009. NCSS, LLC. Kaysville, Utah.

IBIS World Industry Report 33712. 2010. Household Furniture Manufacturing in the US.

Retrieved September 8, 2010 from:

http://www.ibisworld.com/industryus/productsandmarkets.aspx1999-2010.

Kylloe, R. 2006. Hickory Furniture. Gibbs Smith Publication, Layton, Utah, USA, pp 7 - 140. 
McDaniel, P. 2003. Opportunities for the utilization of non - traditional species in wood based component manufacturing. M.S. Thesis, Virginia Polytechnic Institute and State University, Blacksburg, VA.

Ozanne, L. and P. Smith. 1996. Consumer segments for environmentally marketed wooden household furniture. Wood and Fiber Science. 28 (4):461 - 477. 
CHAPTER 3

MARKET PERCEPTIONS OF THE LOCAL COMMUNITY IN WEST VIRGINIA ON APPALACHIAN HARDWOODS ${ }^{2}$

Liberty Olea Moya

${ }^{2}$ To be submitted to Forest Products Journal 


\section{ABSTRACT \\ MARKET PERCEPTIONS ON APPALACHIAN HARDWOODS OF \\ THE LOCAL COMMUNITY IN WEST VIRGINIA}

\section{Liberty Olea Moya}

This study investigated the domestic market opportunities of under-utilized Appalachian hardwoods in the USA. The study aimed to differentiate the similar study conducted among the international community at West Virginia University (WVU). American respondents who took part of this study came from WVU Campus and 2012 Morgantown Home Show (MHS). This research distinguished the levels of concern of the customers who already have shown interests on household wooden products. Under-utilized hardwood species (hard maple, soft maple, hickory and yellow-poplar) were evaluated together with selected commercial species (walnut, red oak, cherry). Respondents answered questions based on their own thoughts and perceptions of the wood species. An assessment was performed related to the physical attributes of seven wood species. This study further evaluated the current perceptions of under-utilized species such as hickory and some possible methods to improve consumers' acceptance.

Results from this replicated domestic study showed similar results with the international community on the top three most preferred species: walnut, hickory and red oak. Americans considered under-utilized hardwoods more sustainable and eco - friendly in the frequency report and in the analysis of proportions (z-test). It was interesting to find that a majority of the American respondents identified cherry, walnut, and yellow-poplar wood species.

Color was the most influential factor among the American respondents in their wood purchasing decisions, as compared to the international community where functionality \& safety was the highest concern. Gender based differences, age, income, levels of experience and expertise in purchasing wooden products were further observed. While both the emotional ads and technical information were found effective, American respondents tend to rely more on technical information when purchasing wood products. Results from this study, could help secondary wood manufacturers in their product designs and promotional marketing strategies when using under-utilized species.

Keywords: Under-utilized species, American market perceptions and preferences, trends on buying behavior, purchasing decisions, sustainable wooden product designs, green marketing, promotional messages. 


\subsection{INTRODUCTION}

The primary aim of this study was to evaluate the domestic market opportunities of under-utilized Appalachian hardwoods among the local community in West Virginia. In the previous study, the preferences of the international community for under-utilized species were identified. Market perceptions on different wood species may vary based on geographic locations and demographics (Nicholls and Bumgardner 2007). Information related to geographical differences is beneficial for putting together strategies on market segmentation and customization of local products (Ozanne and Smith 1995; Pakarinen and Asikainen, 2001, Lages et al. 2008). Moreover, marketing data will assist secondary wooden manufacturers in capitalizing on readily available under-utilized timber in the Appalachian region. Specifically data related to consumers' preferences on wood products are needed to promote Appalachian hardwoods (Bush et al. 1992, Bowe and Bumgardner 2003, Nicholls and Bumgardner 2007).

Under-utilized species would play a greater role in the species substitution to commercial wood species (Bush et al. 1992). The demand for environmentally marketed wood products has been researched in past studies of Ozanne and Smith (1995). However, market acceptance of wood furniture from low grade species had yet to be established. One reason for the reduced usage of lower grade species may be the limited information on consumer preferences about furniture products from low grade species (Wang et al. 2004). Similar to the study in the international community, hickory was again used to evaluate the domestic market acceptance on household wood products out of under-utilized species. The use of these types of species would help alleviate the increasing challenges in the forest products industries.

There is an increasing focus on environmentally friendly, sustainable products. Secondary manufacturers should continuously search for markets on environmentally marketed wood products. Identification of sustainably oriented consumers would help domestic wood manufacturers adopt more competitive 
marketing strategies that will position, promote and advertise their new products (Ozanne and Smith 1995, Pakarinen and Asikainen 2001). The emergence of environmental consumerism has lead to the production of more eco-friendly products. Consumers not only increased their awareness on environmental responsibilities in every purchase, but also expected more from the manufacturers (Ozanne and Smith 1995, Scholz and Decker 2007, Esty and Winston 2009).

Consumer preferences on value-added wooden products are usually attributed with several factors that influenced their purchasing decisions (Bowe and Bumgardner 2004; Nicholls, Bumgardner and Barber 2010). Secondary wood product manufacturers must stay up to date on customers' needs to remain competitive in business. For instance, Scholz and Decker (2007) pointed out how life-cycle of furniture product designs now has become out dated. This can be attributed to the continuous growth of giant retailers like IKEA, that offer more fashioned lifestyle furniture at a cheaper price.

The objectives of this study were: (1) to measure perceptions of the American in West Virginia on the attributes of under-utilized and commercial wood species (2) to compare and contrast the international market perceptions in the previous study with the domestic market (3) to investigate the market potentials of hickory species as an alternative material for commercial wood species; (4) to identify the major end-products derived from hickory species; (5) to differentiate the preferences of the American respondents with the international community in relation to purchasing of wood products (5) to analyze the different factors that influence American respondents in their wood purchasing decisions and; (6) to recommend promotional messages on how to properly position under-utilized species in the domestic market. 


\subsection{MATERIALS AND METHODS}

The survey was conducted from February 27 - March 15, 2012 at West Virginia University (WVU) Campus and in the 2012 Morgantown Home Show (MHS). The study aimed to differentiate the similar study conducted among the international community at West Virginia University (WVU). American respondents who took part of this study came from WVU Campus and 2012 Morgantown Home Show (MHS). This research distinguished the levels of concern of the customers who already have shown interests on household wooden products.

A total of 211 American respondents from WVU Campus (82\%) and MHS (18\%) answered the survey questionnaire. Respondents of 18 years old and older were preferred, as this group has the purchasing power to invest or at least has interests on buying wood products. Basic socio-demographic questions were asked and related to wood purchasing decisions and preferences. Respondents included prospective consumers, industrial practitioners and people from academia. A pre-test was conducted to finalize wording of all the questions. For instance, some of the English words like "stately" were changed into "elegant" while "sustainable" into "eco-friendly".

Specific details of the methodology in this research can be found in the prior study on the international community at WVU's campus (Please refer to Section 2.2 Materials and Methods).

\subsection{RESULTS AND DISCUSSIONS}

\subsubsection{Demographics and socio - economic profile}

Information gathered about the respondents was essential to know their preferences on household wood products. Using the frequency distribution, the sample was $59 \%$ male and $24 \%$ female, with $17 \%$ omitting gender information. Age distributions of the respondents were as follows: 18 to 23 years old $(45 \%)$, 
24 to 29 years old (15\%) and greater than 30 years old (39\%). About $1 \%$ had their age remain undeclared. There were $64 \%$ single respondents, and $33 \%$ married, while $3 \%$ did not answer their marital status. Of these respondents, $19 \%$ were graduate students and $9 \%$ were faculty members of West Virginia University. The rest (64\%) were under a different occupation, while $8 \%$ provided no answer. The highest income group had a monthly income less than $\$ 1,250$ USD per month $(32 \%)$, followed by the income group that range between $\$ 1,251-3,500$ USD (21\%). Of the total respondents, 35\% owned a house, $49 \%$ has past experience in working with wood, and $62 \%$ had been involved in the purchase of household furniture within the last five years. A majority of the respondents were undergraduate students $(44 \%)$, followed by professionals (with bachelor, master and doctorate degrees) at 40\%. Only $4 \%$ has vocational/certificate courses and $11 \%$ did not to declare their educational level. The largest areas of discipline (46\%) of the American respondents were from the "Other Major" (humanities, physical sciences and business), followed by forestry majors (18\%), engineering (17\%), and psychology $(3 \%)$. Of the total respondents, there were only $1 \%$ with designs and architectural background, $1 \%$ that were marketing majors, and $13 \%$ that were undeclared.

\subsubsection{Preferences on wooden species, attributes and glaze on finish}

\section{a. Over - all preference on wooden species}

Figure 3.1, shows the overall preference of the American respondents on seven commercial wooden species. Of the total respondents $(n=211)$, only $76 \%$ were able to completely rank the seven species from 1 to 7 point Likert Scale (with 1 = "Most liked", 7 = "Least liked"). For purposes of comparison between the under-utilized and well-utilized wooden species, only the information derived from completely answered surveys were considered. The top choice wooden species based on the overall preference of the domestic market were: walnut $(30 \%)$, hickory $(20 \%)$, and red oak (20\%). It was noted however, that hickory 
(25\%) gained the highest frequency of being chosen in the ranking of 2, among any other species. The choices for species were similar with the international community. Respondents indicated a statistically significant higher preference for walnut in comparison with all other species at alpha level=0.05. Moreover, survey results indicated a statistically significant higher preference for red oak as compared to soft maple ( $p$-value=0.0123), yellow-poplar and hard maple ( $p$-values $=0.0000)$. Respondents indicated a statistically significant higher preference for cherry as compared to yellow poplar ( $p$-value $=0.0016$ ) and hard maple ( $p$-value $=0.0001)$. Based on these results, American respondents showed less preference for soft maple, yellow-poplar and hard maple. Past research has shown that the preferences for a certain wood species were closely connected to their daily experiences with those types of wood (Scholz and Decker 2007). Perhaps, this linkage partly explains why a majority of local community preferred commercial wooden species. There was an already established association with the well used species in their household wood products. Among the underutilized species, respondents showed a statistically significant higher preference for hickory as compared to soft maple ( $p$-value $=0.0084$ ), yellow-poplar ( $p$-value $=0.0272)$, and hard maple ( $p$-value $=0.0021)$.

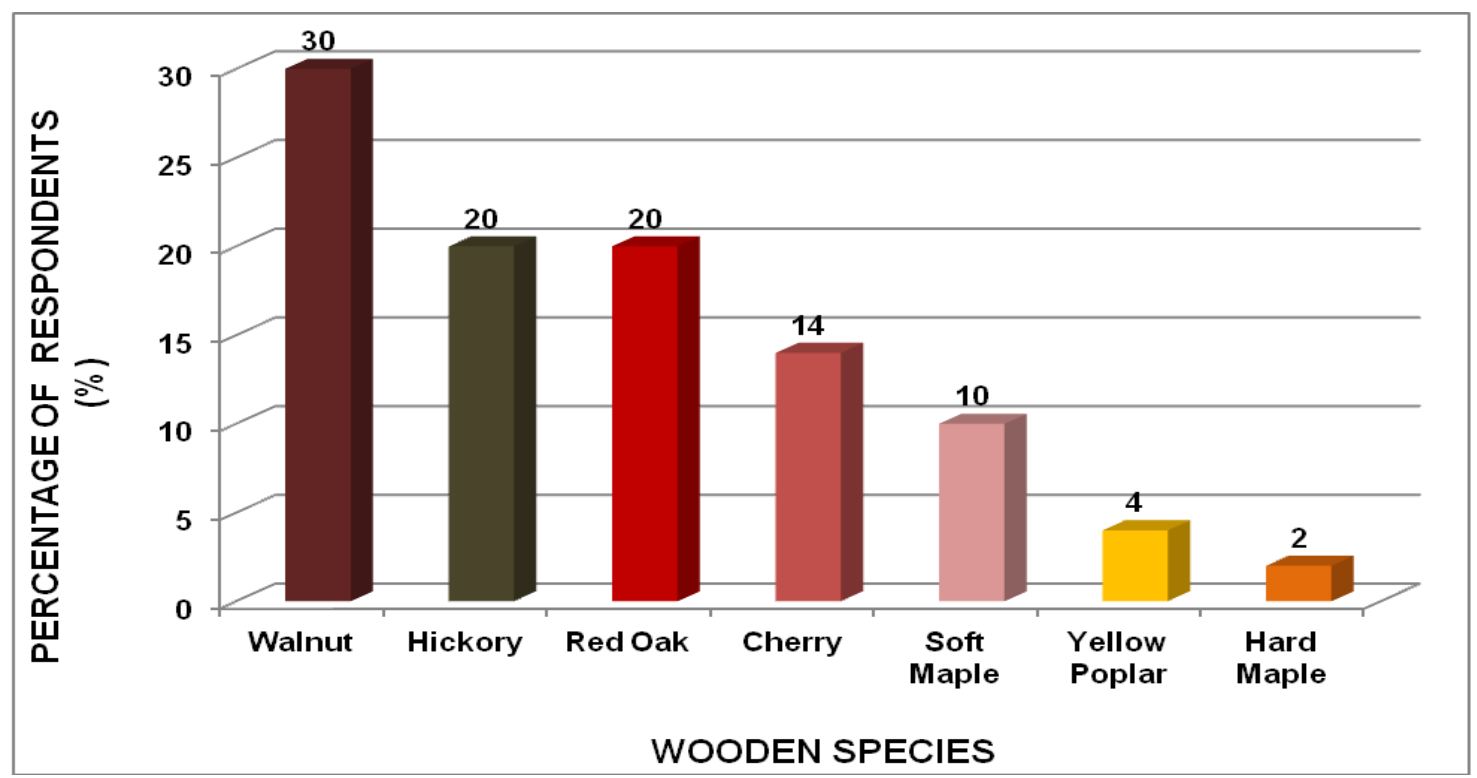

Figure 3.1 Over-all preferences on wood species among the local community. 


\section{b. Wood attributes}

Of the total respondents, $60 \%$ completed the ranking of 1 to 3 per wooden species attributes. Response rate however, was higher as compared with the international community. Table 3.1, shows the top choices for wooden species based on ranking per attribute ( $1=$ Most Liked). Ranking was calculated based on the total respondents who completely answered the survey on a per category basis. Among all species that made to the top 1 list, walnut has the highest number of number 1 ranking.

It should be noted that the hickory wooden sample used was not multicolored (only heartwood) and therefore the results found really only pertain to hickory with a high percentage of heartwood. Darker wooden samples (walnut \& hickory) were again perceived to be more durable, expensive, elegant and formal. Similar results were observed in the past research, with regards to species selection and wood perceptions (Bowe and Bumgardner 2004). In relation to modern style attribute, respondents indicated that various wooden species were selected. This was consistent in the past researches were the choice for wooden species depends on the product design (Wang et al. 2004, Brinberg et al. 2007). In comparison with the results of the international market study, walnut was consistently chosen to have the most calming effect. Other selected species with calming effect varied. For instance, cherry and soft maple was considered calming by the American respondents, while yellow-poplar and hard maple were the choice of the international community. It was interesting to note that among the under-utilized species, hickory was well liked in most of the different categories. This indicates that hickory has potential to be an alternative species. Similar to the results obtained from the international community study, hickory was always chosen next to the commercial species in the ranking of 1 (i.e., highest number of \#2 rankings).

Frequency reports showed that lighter woods (yellow-poplar, hard maple and soft maple) were again perceived as more sustainable species. Respondents indicated that soft maple had a statistically significant higher 
sustainability as compared to yellow-poplar ( $p$-value $=0.0384$ ), but not with hard maple ( $p$-value $=0.6352$ ). There was no statistical significant evidence that hard maple was a more sustainable species than yellow-poplar $(p$-value $=0.1090)$.

Table 3.1 Top choice wooden species based on ranking per attribute.

\begin{tabular}{|c|c|c|c|c|}
\hline \multirow[b]{2}{*}{ Attributes } & \multicolumn{3}{|c|}{ Top Rank Choices (\%) } & \multirow{2}{*}{$\begin{array}{c}\% \\
\text { RESPONDENTS } \\
\mathrm{N}=211\end{array}$} \\
\hline & $\# 1$ & \#2 & \#3 & \\
\hline Durability & $\begin{array}{l}\text { Walnut(35) } \\
\text { Hickory (20) } \\
\text { Red Oak (18) }\end{array}$ & $\begin{array}{c}\text { Hickory (30) } \\
\text { Soft Maple (15) } \\
\text { Red Oak \& Walnut (14) }\end{array}$ & $\begin{array}{c}\text { Hickory \& Walnut (20) } \\
\text { Red Oak (19) } \\
\text { Soft Maple (15) }\end{array}$ & 60 \\
\hline Expensive & $\begin{array}{l}\text { Walnut (55) } \\
\text { Hickory (17) } \\
\text { Red Oak (10) }\end{array}$ & $\begin{array}{l}\text { Hickory (34) } \\
\text { Red Oak (16) } \\
\text { Cherry (15) }\end{array}$ & $\begin{array}{c}\text { Red Oak (23) } \\
\text { Hickory (19) } \\
\text { Cherry(18) }\end{array}$ & 59 \\
\hline Elegant & $\begin{array}{l}\text { Walnut (36) } \\
\text { Hickory (24) } \\
\text { Cherry (14) }\end{array}$ & $\begin{array}{c}\text { Hickory (27) } \\
\text { Walnut (19) } \\
\text { Red Oak (18) } \\
\end{array}$ & $\begin{array}{l}\text { Red Oak (20) } \\
\text { Soft Maple (18) } \\
\text { Hickory (17) } \\
\end{array}$ & 60 \\
\hline Formal Look & $\begin{array}{l}\text { Walnut (48) } \\
\text { Hickory (19) } \\
\text { Red Oak (13) }\end{array}$ & $\begin{array}{c}\text { Hickory (31) } \\
\text { Walnut (16) } \\
\text { Hard Maple (16) }\end{array}$ & $\begin{array}{l}\text { Red Oak (21) } \\
\text { Hickory (20) } \\
\text { Soft Maple (16) }\end{array}$ & 60 \\
\hline Modern Style & $\begin{array}{l}\text { Walnut \& Cherry (18) } \\
\text { R. oak \& Hickory (15) } \\
\text { Hard Maple (14) }\end{array}$ & $\begin{array}{c}\text { Hickory (24) } \\
\text { Red Oak (15) } \\
\text { Y. Poplar \& Cherry (14) } \\
\end{array}$ & $\begin{array}{c}\text { Yellow-poplar (17) } \\
\text { Walnut (16) } \\
\text { Red Oak (15) } \\
\end{array}$ & 58 \\
\hline $\begin{array}{l}\text { Calming } \\
\text { Effect }\end{array}$ & $\begin{array}{c}\text { Walnut (19) } \\
\text { Cherry (18) } \\
\text { Soft Maple (16) } \\
\end{array}$ & $\begin{array}{c}\text { Hickory (29) } \\
\text { Hard Maple (18) } \\
\text { Walnut (17) }\end{array}$ & $\begin{array}{c}\text { S. Maple, Hickory \& Walnut (17) } \\
\text { Red Oak (13) } \\
\text { Y. Poplar \& Cherry(12) }\end{array}$ & 57 \\
\hline $\begin{array}{l}\text { Eco-friendly/ } \\
\text { Sustainable }\end{array}$ & $\begin{array}{l}\text { Hard Maple (23) } \\
\text { Soft Maple (20) } \\
\text { Yellow-poplar (18) }\end{array}$ & $\begin{array}{l}\text { Hard Maple (25) } \\
\text { Yellow-poplar (21) } \\
\text { Red Oak (15) }\end{array}$ & $\begin{array}{c}\text { Soft Maple (20) } \\
\text { Hickory (20) } \\
\text { Cherry (17) }\end{array}$ & 56 \\
\hline
\end{tabular}

\section{c. Glaze Preference: Glossy vs. Matte}

Figure 3.2, shows the results of the respondent's preference between glossy and matte finish on a hickory sample. Results indicated that there was a statistically significant difference among the American respondents that preferred hickory with a natural finish ( $p$-value $=0.0000$ ). This was in contrast with the international community respondents that did not show a preference for finish type. 


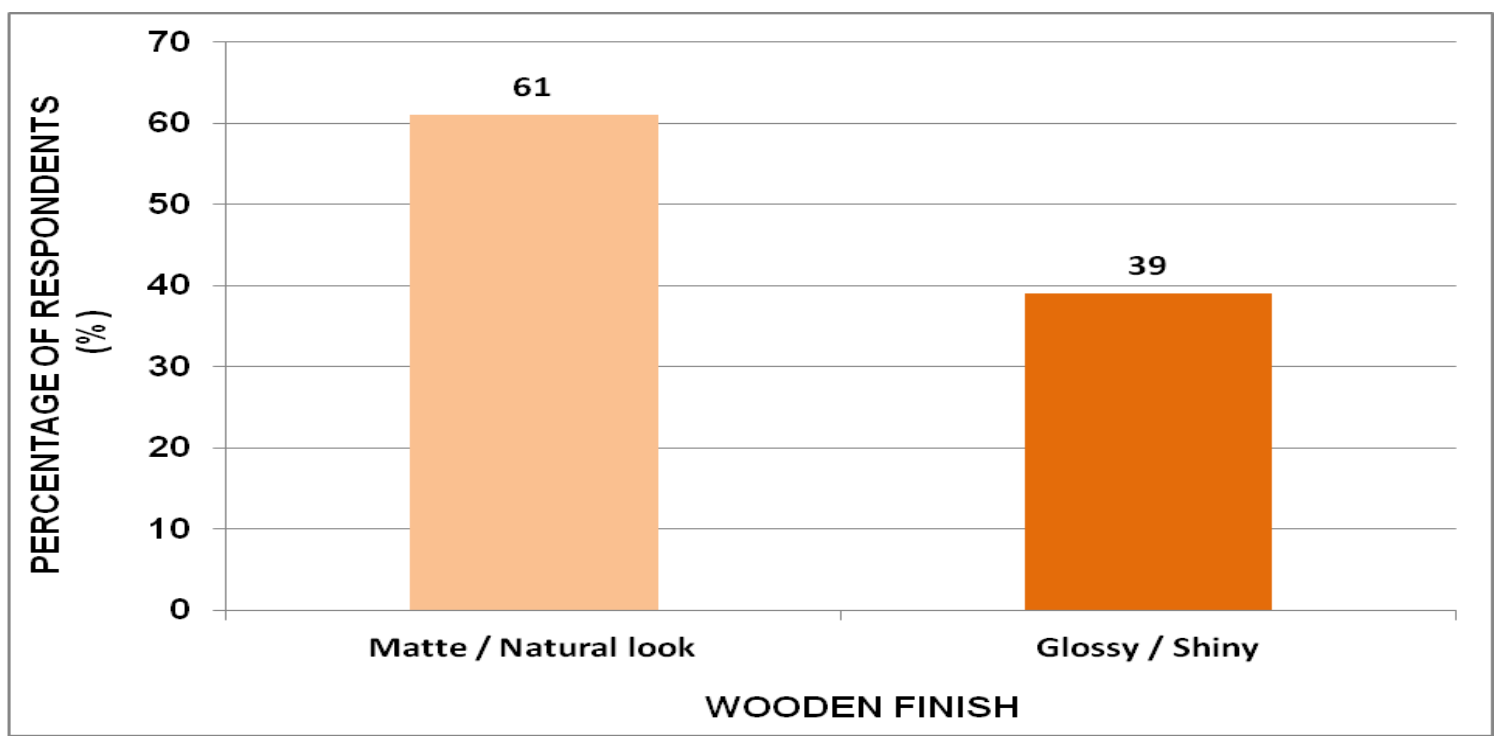

Figure 3.2 Over-all preferences of the American respondents on the glaze of the wood finish.

\subsubsection{Preferences based on demographics and socio - economic profile}

Respondents were asked to rank all seven species based on overall preference ( $1=$ Most preferred, $7=$ Least preferred). For each species, a success was considered as the respondents ranking that species with a number 1 , while all other rankings (2-7) were considered as failures. Results from twoproportion (z-test) analysis indicated that there was a statistically significant difference in the preference for walnut between males and females (Table 3.2).

Table 3.2. Gender preference on wooden species most ranked number 1.

\begin{tabular}{|c|c|c|c|}
\hline \multirow{2}{*}{ Species } & \multicolumn{2}{|c|}{ Number of Successes } & \multirow{2}{*}{} \\
\cline { 2 - 3 } & Female & Male & p-value \\
\hline Cherry & 5 & 15 & 1.0000 \\
Hickory & 6 & 19 & 0.8983 \\
Soft Maple & 6 & 8 & 0.1033 \\
Hard Maple & 2 & 1 & 0.0919 \\
Red Oak & 8 & 18 & 0.4500 \\
Walnut & 6 & 37 & $0.0431^{*}$ \\
Yellow Poplar & 1 & 4 & 0.7925 \\
TOTAL & 34 & 102 & \\
\hline
\end{tabular}

* indicates a statistically significant difference at alpha level $=0.05$. 
For all other species there was no statistically significant difference in overall preference based on gender. These findings were also consistent with the results of the international community study where walnut was preferred differently by males and females. The preference of male respondents for walnut was significantly evident of their preference for a dark colored species (Figure 3.3). This was in contrast to the past research where there was a general preference for lighter woods such as maple among male respondents (Nichols and Bumgardner 2007).

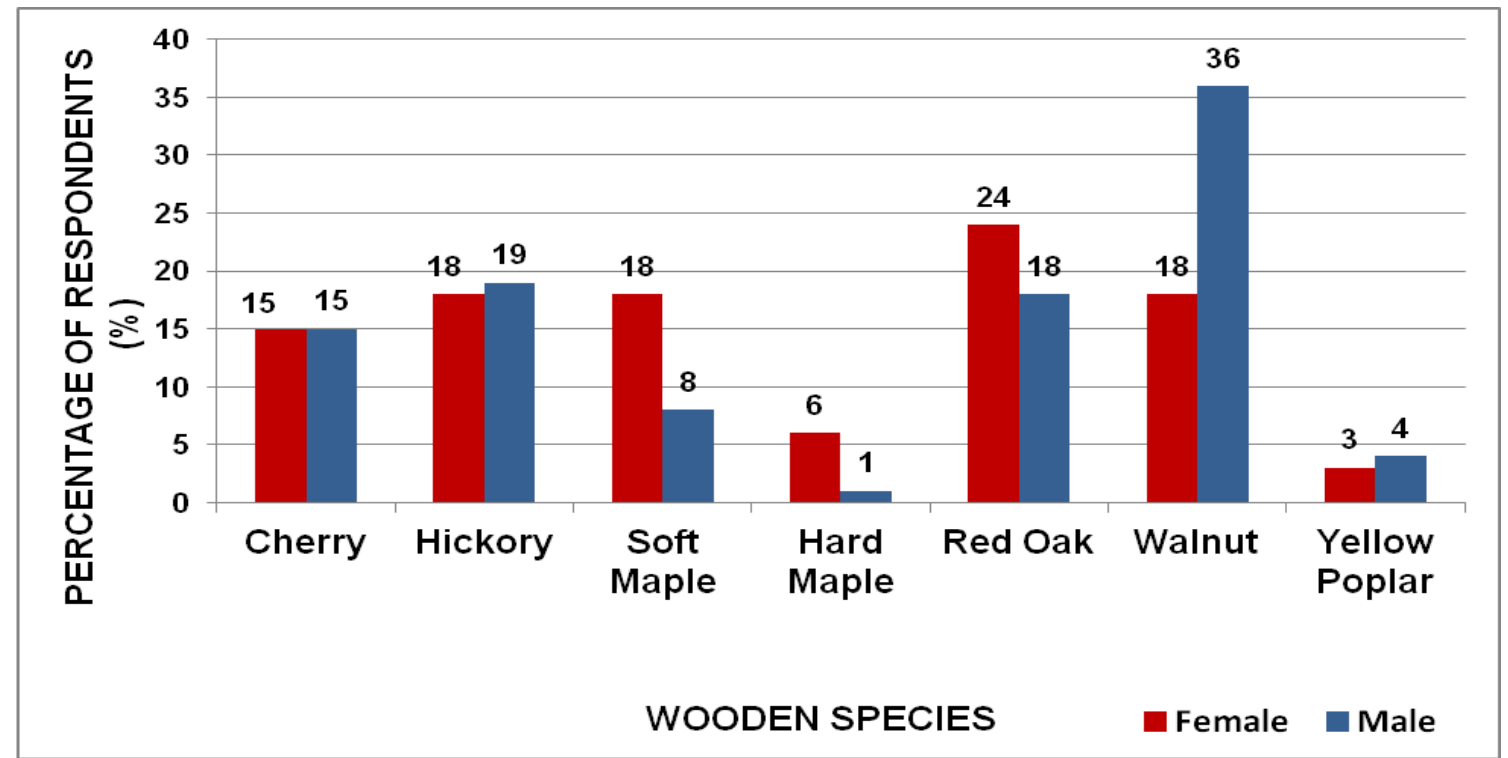

Figure 3.3 Percentage ranking of the most preferred species based on gender.

Although, older age groups were more preferred due to their higher purchasing power, it turned out that majority of the respondents were 18 to 23 years old (45\%). Bowe and Bumgardner (2004) however, suggested that college students could represent the adult consumer's perceptions on wooden species. Their answers therefore, could still serve as future consumers of wooden products. Results showed that there was a statistical significant difference in the preference for cherry, hard maple and walnut with regards to age (Table 3.3). 
Table 3.3 Cross tabulation results based on preference for species with regards to age.

\begin{tabular}{|ccc|}
\hline Species & $\begin{array}{c}\text { Chi-Square } \\
\mathrm{df}=12 \\
\mathrm{n}=161\end{array}$ & p-values \\
\hline Cherry & 24.8451 & $0.0156^{*}$ \\
Hickory & 12.0638 & 0.4406 \\
Soft Maple & 11.8282 & 0.4596 \\
Hard Maple & 21.7038 & $0.0410^{*}$ \\
Red Oak & 12.1772 & 0.4316 \\
Walnut & 22.2126 & $0.0352^{*}$ \\
Yellow-poplar & 9.3166 & 0.6757 \\
\hline
\end{tabular}

${ }^{*}$ indicates a statistically significant difference at alpha level $=0.05$.

$\mathrm{df}=$ degrees of freedom.

To further evaluate which age categories had statistically significant difference on top ranked species, analysis of proportions was used. The respondent's preference for walnut and cherry were statistically significant between age groups 24-29 years old and $\geq 30$ years old (Table 3.4). This finding suggests a possible sudden drop in the preference on walnut as the Americans get older. Perhaps, as the Americans reached 30 and above, the choice for the most expensive wooden products out of walnut was no longer practical. However, this issue was not specifically tested in this particular study and requires further investigation.

Table 3.4 The top most preferred species with regards to age categories.

\begin{tabular}{|cccc|}
\hline \multicolumn{3}{c}{ Age Category } \\
Species & 18-23 and 24-29 & 24-29 and $>30$ & $18-23$ and $>30$ \\
\hline Cherry & 0.4894 & $0.0175^{\star}$ & $0.0041^{*}$ \\
Hickory & 0.9778 & 0.7424 & 0.6773 \\
Red Oak & 0.1576 & 0.5041 & 0.2978 \\
Walnut & 0.3135 & $0.0053^{*}$ & $0.0215^{\star}$ \\
\hline * indicates a statistically significant difference at alpha level $=0.05$.
\end{tabular}

In comparison with the international community, Figure 3.4, indicated that Americans showed a statistically significant preference for walnut, as compared to red oak when considering the age group 24-29 years old ( $p$-value=0.0385). 
However, on age group $\geq 30$ years old, the preference for walnut was only statistically significant when compared with hard maple and yellow-poplar ( $p$-values=0.0147).

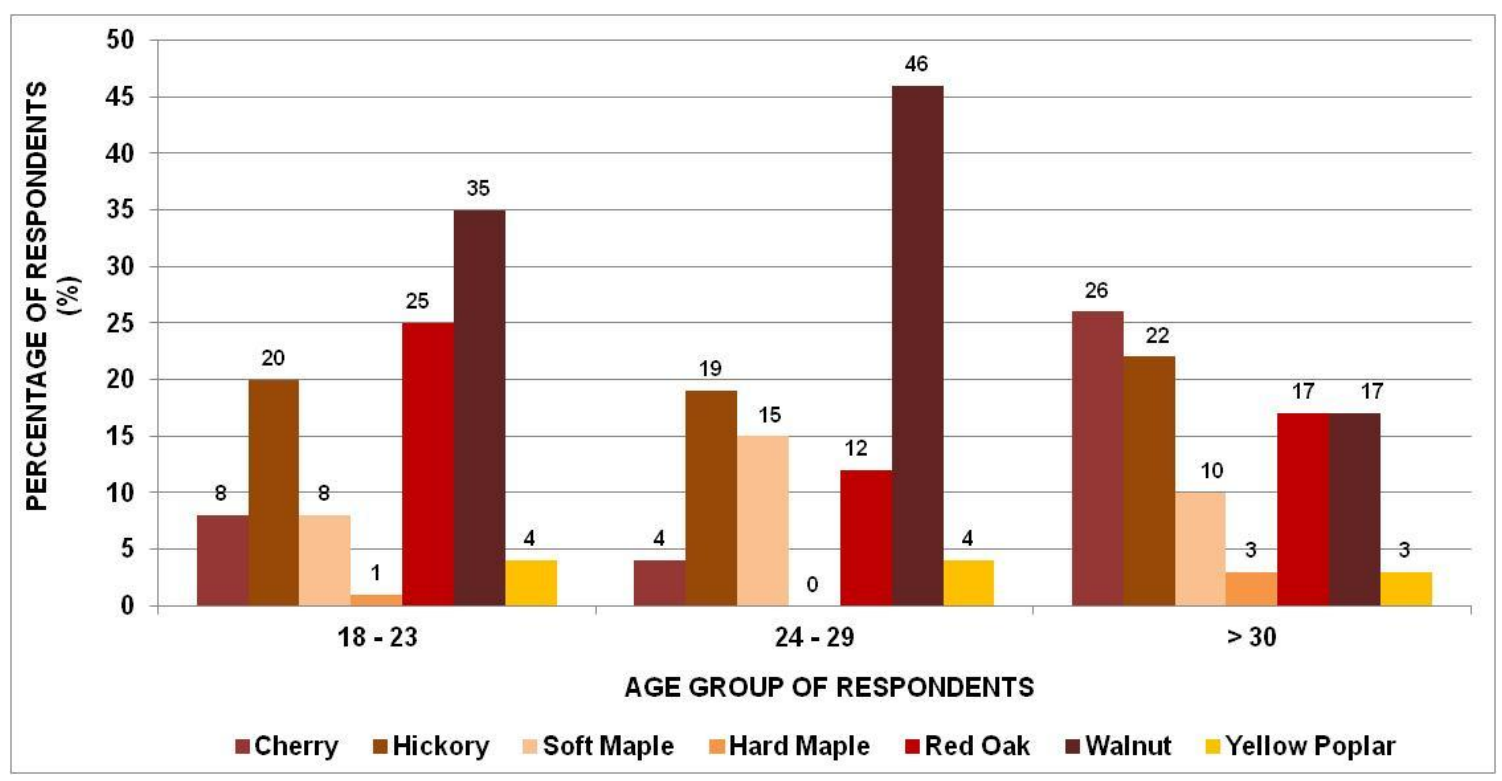

Figure 3.4 Percentage ranking of the most preferred species based on age group.

There was no statistical significant evidence that the preference for cherry was higher than walnut and red oak as Americans reached age group $\geq 30$ years old ( $p$-value $=0.2589$ ). This was similar to the past research where red oak was the popular species among the older group (Nicholls and Bumgardner, 2007). Unlike with the international community, there was no pattern established whether darker wood color was more preferred when American respondents aged. It was interesting that all of the age groups had a moderate acceptance with hickory.

In the analysis of age group $\geq 30$ years old, most of the under-utilized species, except for hickory were never preferred (Table 3.5). This showed a negative response on the market acceptability of under-utilized species based on 
age group. This observation must be carefully considered when delivering promotional messages about the under-utilized species.

Table 3.5 Preference on commercial species for age group $>30$ years old.

\begin{tabular}{|c|c|c|c|}
\hline \multirow[t]{2}{*}{ Species } & \multicolumn{3}{|c|}{$\begin{array}{c}\text { Age group }>30 \text { years old } \\
\text { p-value }\end{array}$} \\
\hline & Cherry & Red oak & Walnut \\
\hline Cherry & - & 0.2589 & 0.2589 \\
\hline Hickory & 0.6643 & 0.4848 & 0.4848 \\
\hline Soft Maple & $0.0300^{*}$ & 0.2815 & 0.2815 \\
\hline Hard Maple & $0.0006^{*}$ & $0.0147^{*}$ & $0.0147^{*}$ \\
\hline Red Oak & 0.2589 & - & 1.0000 \\
\hline Walnut & 0.2589 & 1.0000 & - \\
\hline Yellow-poplar & $0.0006^{*}$ & $0.0147^{*}$ & $0.0147^{*}$ \\
\hline
\end{tabular}

* indicates a statistically significant difference at alpha level $=0.05$.

Walnut was the top most preferred species based on income. This species was used to check the significance levels of other wooden species per income group. It was noted that the higher preference for walnut was significantly evident on income group $<\$ 1,250$ (Table 3.6). This was in contrast to the past research where red oak became the most popular choice among the lower income group (Nichols and Bumgardner, 2007). Differences between results in this study as compared to prior studies may be due to variations in the segmentation of gender, age and income categories. Moreover, it was still undetermined whether differences in survey results were influenced by price or current design trends.

Table 3.6 Preference for walnut species over other species based on income.

\begin{tabular}{|cccccc|}
\hline $\begin{array}{c}\text { Walnut vs. } \\
\text { Other species }\end{array}$ & \multicolumn{5}{c|}{$\begin{array}{c}\text { p-value } \\
\text { Income Group }\end{array}$} \\
& $<1,250$ & $\$ 1,251-3500$ & $\$ 3501-5000$ & $\$ 5001-7500$ & $>\$ 7,500$ \\
\hline Walnut & 1.0000 & 1.0000 & 1.0000 & 1.0000 & 1.0000 \\
Red Oak & $0.0406^{*}$ & 0.0890 & 0.4261 & 0.5371 & 0.2482 \\
Cherry & $0.0002^{*}$ & 0.4224 & 0.6313 & 0.6152 & 0.6299 \\
Hickory & $0.0124^{*}$ & 0.2763 & 0.4261 & 0.3458 & 0.6299 \\
Soft Maple & $0.0001^{*}$ & $0.0422^{*}$ & 0.6313 & 1.0000 & 0.6737 \\
Hard Maple & $0.0000^{*}$ & $0.0003^{*}$ & 0.2904 & 0.1396 & 0.2888 \\
Yellow-poplar & $0.0000^{*}$ & $0.0016^{*}$ & 0.2904 & 0.1396 & 0.0704 \\
\hline
\end{tabular}

${ }^{*}$ indicates a statistically significant difference at alpha level $=0.05$. 
Cherry and hard maple displayed inconsistencies in relation to the increase level of income. Yellow Poplar on the other hand, showed a negative acceptance among higher income groups as compared with other species (Figure 3.5).

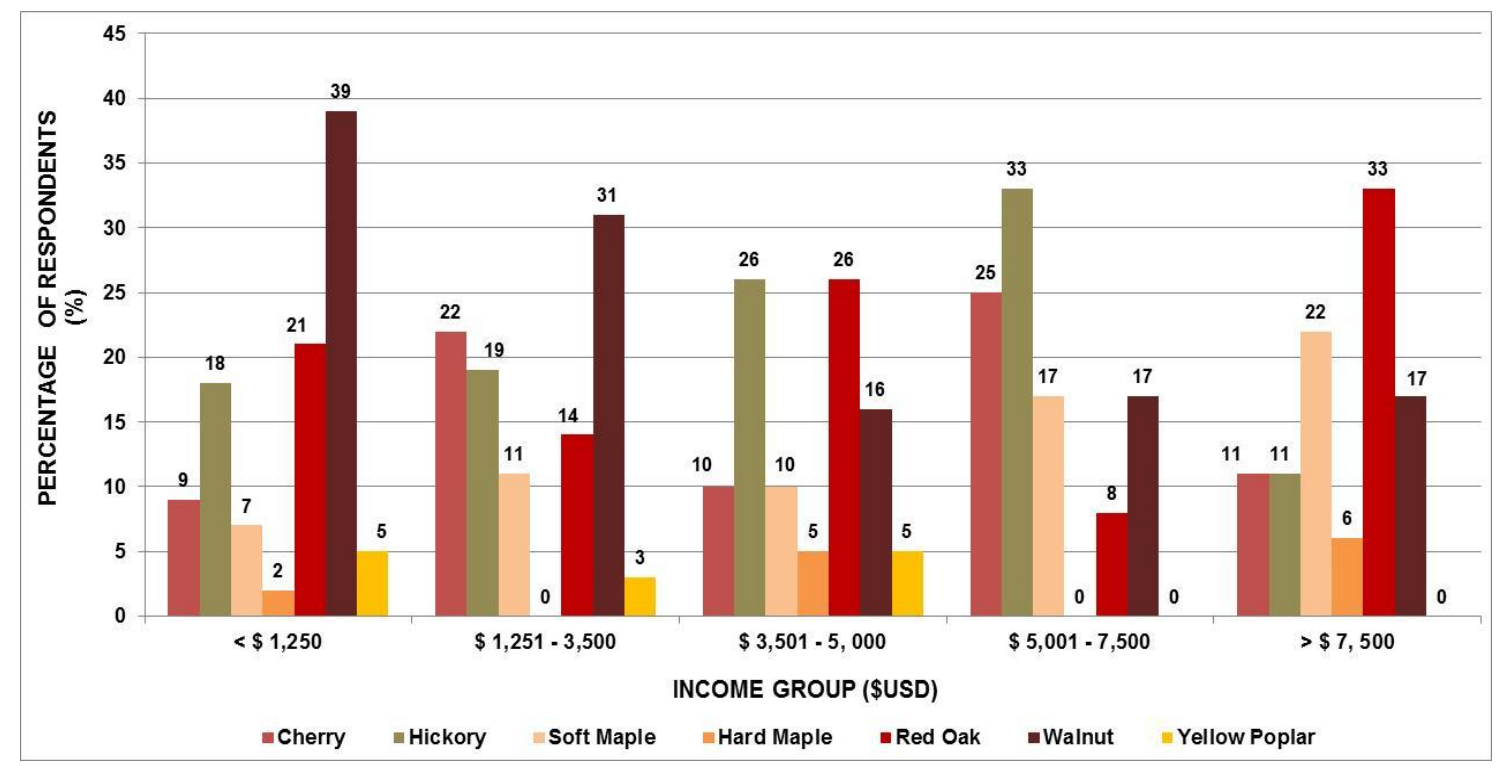

Figure 3.5 Percentage ranking of the most preferred species based on income group.

\subsubsection{Wood Identification and Finish Recognition}

Species identification was essential to gauge the familiarity that American respondents had with wood species used for wood products. Information gathered was relevant to determine whether Americans would care more about the wood species or the applied finish when purchasing products. Through this type of analysis, secondary wooden manufacturers would be able to apply wood finishing techniques that will make under-utilized species look like other wood species.

The ability of respondents to correctly identify each species is shown in Table 3.7. Unlike with the international community, a majority (50\% success rate or higher) of American respondents ( $n=153)$, correctly identified cherry, walnut, and yellow-poplar. Yellow-poplar was the most successfully identified species by 
the American respondents. This finding was similar to the international respondents that also were most successful in identifying yellow-poplar.

Table 3.7 Wooden species identification with their most misidentified counterparts by percentage.

\begin{tabular}{|c|c|c|}
\hline Species & $\begin{array}{c}\text { Respondents correctly } \\
\text { Identifying (\%) }\end{array}$ & $\begin{array}{c}\text { Species Most Incorrectly Identified } \\
\text { (\% of Respondents) }\end{array}$ \\
\hline Cherry & 53 & Red oak (14) \\
\hline Hickory & 36 & Soft Maple (24) \\
\hline Soft Maple & 20 & Hard Maple (34) \\
\hline Hard Maple & 22 & Soft Maple (24) \\
\hline Red Oak & 43 & Cherry (17) \\
\hline Walnut & 50 & Hickory (15) \\
\hline Yellow Poplar & 60 & Hard Maple (13) \\
\hline
\end{tabular}

Using the frequency distribution, five sets of the samples with different finishes out of seven, were recognized as being the same (Figure 3.6). It was interesting to note, that the foreign nationalities were able to recognize wood samples $1 \& 2$ as both hickory species while the American respondents did not ( $p$-value $=0.0272$ ). Moreover, American respondents were not able to recognize significantly the difference ( $p$-value $=0.0000$ ) between hickory (spice finish) and red oak (honey spray finish). This finding was similar to the findings of the international community study, specifically with Indian and KSA respondents. American respondents thought the two wooden samples were also of same species $(76 \%)$. Consistent results from this observation could be attributed to the uniform color of hickory spice wooden sample that was used to compare with the red oak (with honey spray). This indicated that investments on lumber sorting and wood finishing techniques could help assist hickory in being an alternative material for markets where red oak is important. 


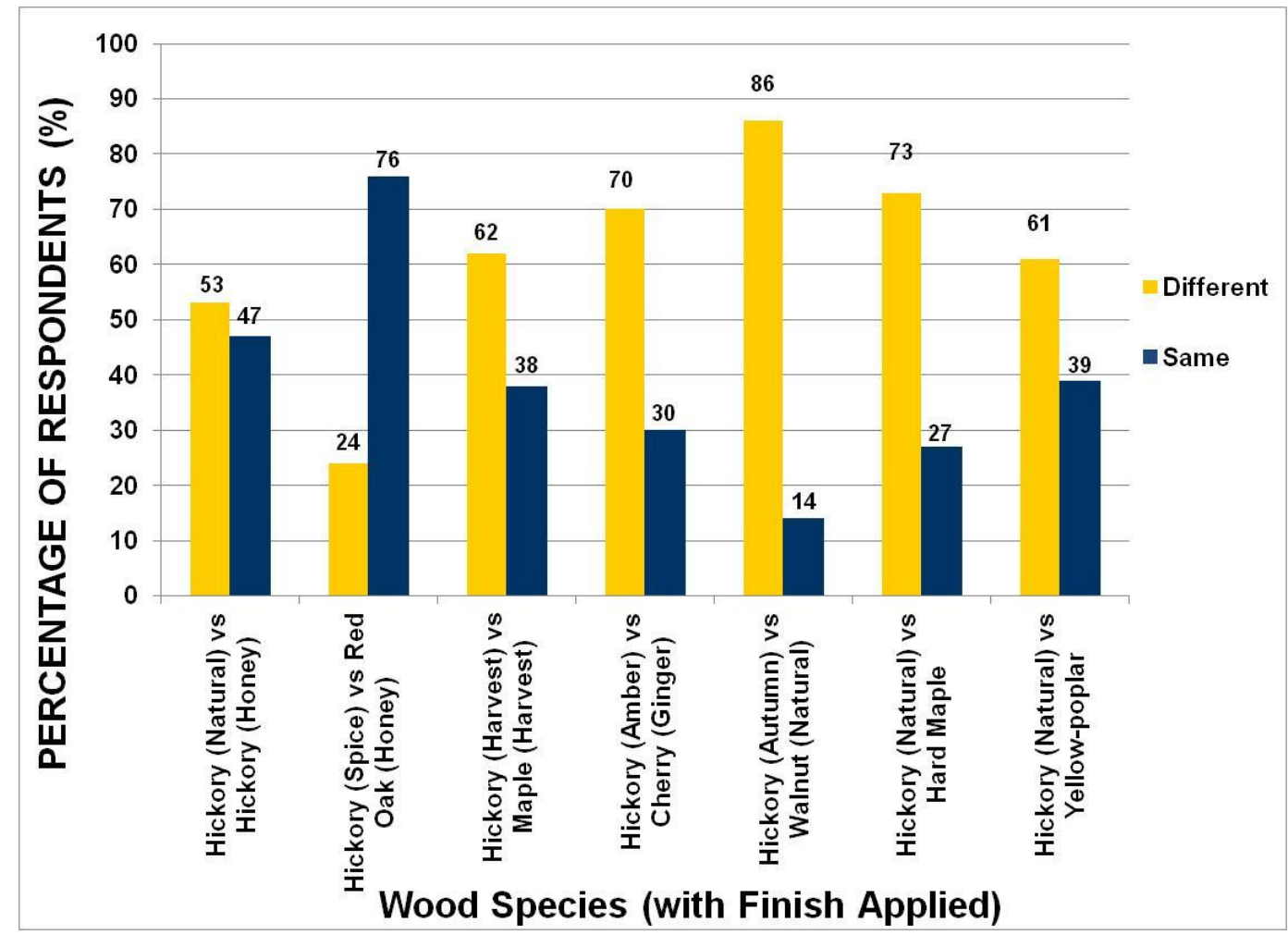

Figure 3.6 Identification of species with various applied stains.

\subsubsection{Species Determination and Levels of Expertise}

The ability of the respondents to determine wooden species was examined based on: wood experience, major or field of discipline, and purchase involvement. In this study, $49 \%$ of the total respondents had experience in working with wood products. Although $64 \%$ of the respondents do not own a house, majority of them were involved in the purchase of furniture $(62 \%)$ during the last five years.

Wood experience is assumed to be an important contributing factor in the purchasing decisions of household wood products. Results showed a statistically significant difference in the identification of red oak, walnut and hickory based on wood working experience (Table 3.8). Soft maples was the most unidentified species among the American respondents with wood working experience, as 
compared to hickory for the internationals respondents in the previous study (Figure 3.7). Perhaps, this difference was due to the ability of the American respondents in distinguishing between soft and hard maple. These results are consistent with past research that investigated species identification of maple among Americans (Bowe and Bumgardner 2004).

Table 3.8 The level of significance in the species determination based on the level of woodworking experience.

\begin{tabular}{|cccc|}
\hline & \multicolumn{2}{c|}{ Wood Working Experience } \\
& \multicolumn{2}{c|}{ Number of Successes } & p-values \\
Species & Without & With & \\
\hline Cherry & 33 & 47 & 0.0532 \\
Hickory & 19 & 36 & $0.0086^{*}$ \\
Soft Maple & 19 & 11 & 0.0732 \\
Hard Maple & 12 & 21 & 0.1095 \\
Red Oak & 19 & 46 & $0.0000^{*}$ \\
Walnut & 27 & 49 & $0.0012^{*}$ \\
Yellow Poplar & 42 & 49 & 0.4459 \\
\hline
\end{tabular}

* indicates a statistically significant difference at alpha level $=0.05$.

Red oak identification had huge gaps of discrepancy (33\%) between respondents with and without experience $(p$-value $=0.0000)$. In contrast to the previous study of Bowe and Bumgardner (2004), results showed that American respondents were able to better identify every species (except for soft maple), when they had prior wood working experience.

It is interesting note that yellow-poplar remain consistent as being the most identified species without experience in wood working. Perhaps, this could be attributed to its yellowish color, and or familiarity with the species due to its abundance in the Appalachian region. 


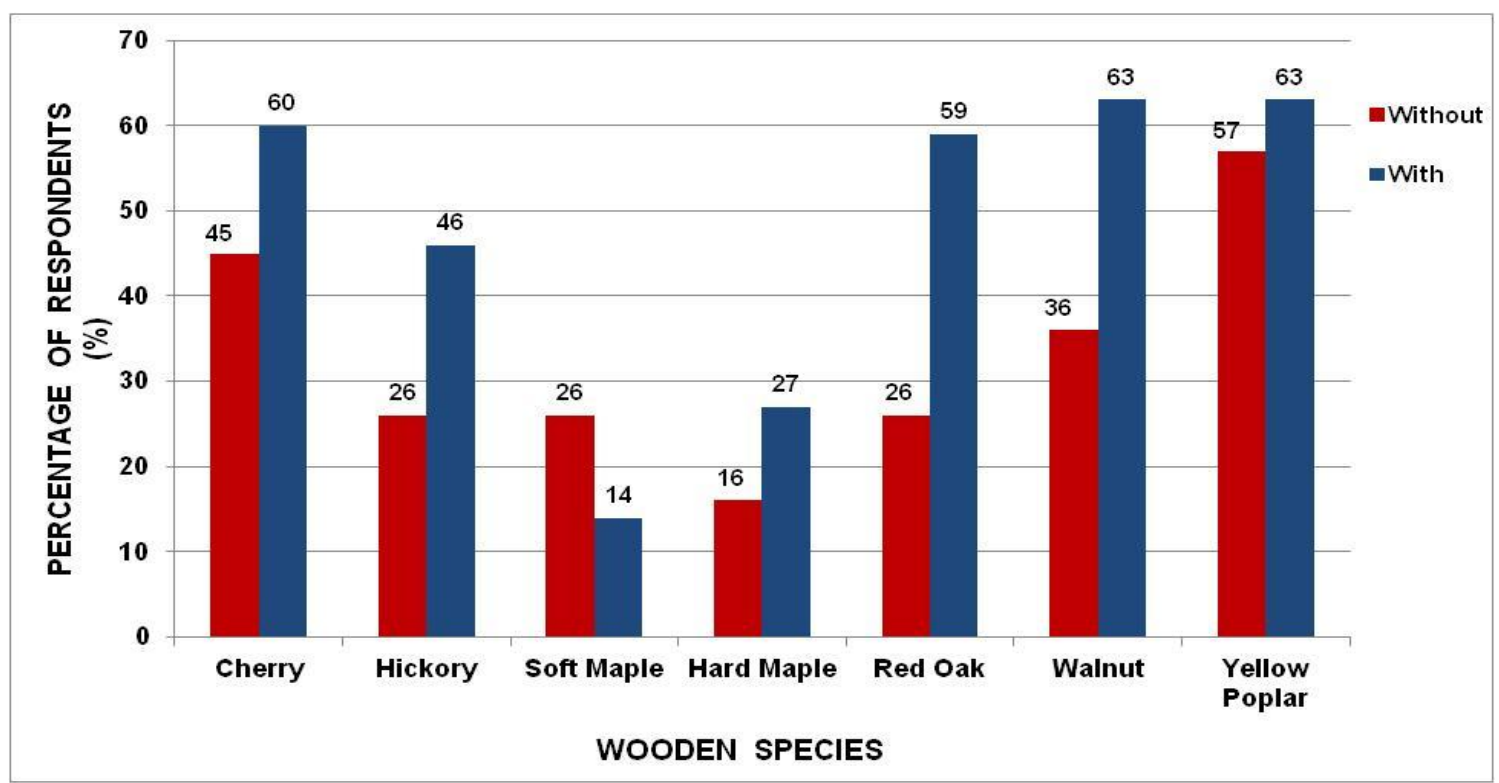

Figure 3.7 Species correctly identified based on the levels of experience in working with wood.

For the species determination based on major or field of discipline ( $\mathrm{N}=211)$, comparison was only focused on Engineering, Forestry, and Other Majors (Humanities, Physical Sciences and Business). The rest of the disciplines were disregarded due to small size. Future research that better covers a broader range of different backgrounds is, however, warranted to fully understand the role that education plays in wood species identification. Jonnson et al. (2008), also supported that larger populations of structural engineers, architects, builders and other professionals must be considered in the conduct of study on consumer preferences for wooden species.

With yellow-poplar as the most significantly identified species, the level of significance in the identification of other species was compared with this species (Table 3.9). Engineering majors (17\%), were able to identify yellow-poplar (66\%), but were unable to identify the other under-utilized species (hickory, soft maple and hard Maple). These results were similar to the findings of the study on the international community. 
Table 3.9 The level of significance in the identification of yellow-poplar with other species based on the discipline of respondents.

\begin{tabular}{|c|ccc|}
\hline $\begin{array}{c}\text { Yellow-poplar } \\
\text { vs. } \\
\text { Other species }\end{array}$ & & & \\
& & p-values & \\
& Engineering & Forestry & Other Major \\
\hline Cherry & 0.0654 & 0.4688 & 0.3768 \\
Hickory & $0.0038^{*}$ & 0.6317 & $0.0001^{*}$ \\
Soft Maple & $0.0002^{*}$ & $0.0004^{*}$ & $0.0000^{*}$ \\
Hard Maple & $0.0000^{*}$ & $0.0049^{*}$ & $0.0000^{*}$ \\
Red Oak & $0.0086^{*}$ & 0.3300 & $0.0028^{*}$ \\
Walnut & $0.0181^{*}$ & 0.0787 & $0.0085^{*}$ \\
Yellow Poplar & - & - & - \\
\hline * indicates a statistically significant difference at alpha level $=0.05$
\end{tabular}

* indicates a statistically significant difference at alpha level $=0.05$.

Environmental consumerism has greatly affected the hardwood industries (Ozanne and Smith, 1996). The success of green marketed products (such as woodproducts out of under-utilized species) has to win the approval of environmental practitioners (Esty and Winston, 2009). In this study, it was consistent that American Forestry majors (18\%) had difficulty in the identification of soft maple ( $p$-value $=0.0004$ ) and hard maple ( $p$-value $=0.0049)$. A majority of the Other Major respondents (46\%) were able to identify yellow-poplar (60\%) and cherry (52\%).

The purchase involvement for the last five years on furniture products was used to check the expertise in wood identification. In general, the most identified species based on the purchase involvement of furniture during the last five years were yellow-poplar (60\%), cherry (53\%) and walnut (50\%). Familiarity with the said species could be attributed to the availability of these hardwoods used for furniture in the market. In comparison to other species, frequency report showed that only few American respondents were able to identify soft maple (21\%) and hard maple (24\%) regardless of the levels of experience (Figure 3.8). 


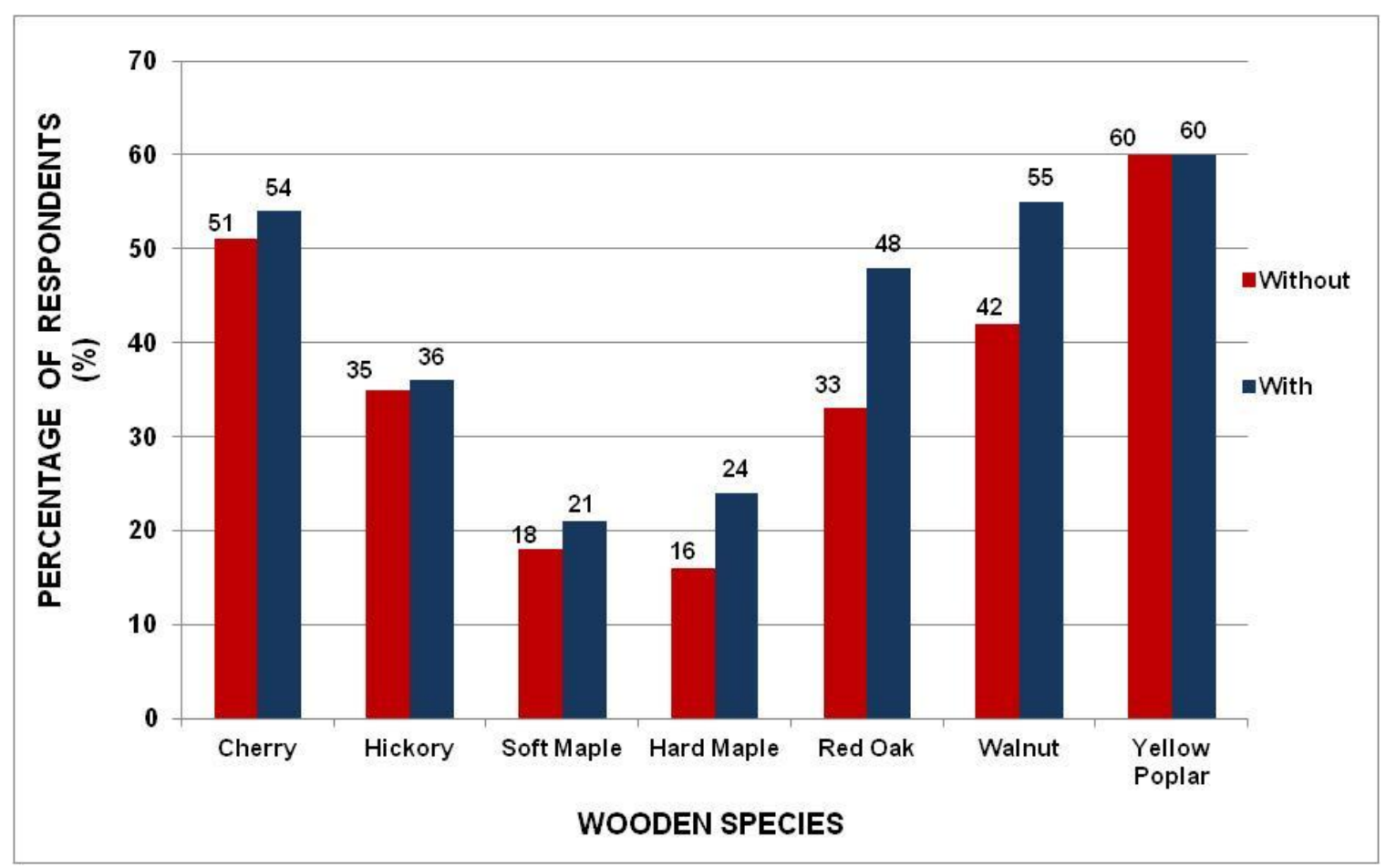

Figure 3.8 Species correctly determined based on the past experience in purchasing furniture.

Similar with the results in the international community, there was no statistical significant evidence that the identification of species increased with regards to purchasing involvement for the last five years (Table 3.10).

Table 3.10 The level of significance in the correct identification of species based on the past experience in purchasing furniture for the last five years.

\begin{tabular}{|cc|}
\hline Species & $\begin{array}{c}\text { With VS Without } \\
\text { Purchase } \\
\text { Involvement } \\
\text { p-values }\end{array}$ \\
\hline Cherry & 0.7372 \\
Hickory & 0.9303 \\
Soft Maple & 0.5988 \\
Hard Maple & 0.2059 \\
Red Oak & 0.0687 \\
Walnut & 0.1316 \\
Yellow Poplar & 0.9659 \\
\hline
\end{tabular}




\subsubsection{Major hardwood products demand projections out of hickory}

Analysis was performed to determine what type of wood products that the American respondents would consider purchasing if they were made from hickory. Figure 3.9, shows the top 3 choices for the hickory products among the American respondents: kitchen cabinets (83\%), wardrobe cabinets (78\%) and doors (75\%). Most of the Americans preferred hickory for household wood products. In regards to moulding, unlike with the international community (48\%), mouldings (70\%) were ranked higher among the American respondents. This suggested that hickory wood has seen potentials for baseboards and cornice in the buildings or residential houses. International community respondents considered hickory wood more for wooden ladders (65\%), as compared to the American respondents (54\%). Similar with the results of the international community, hickory wood was not a favorite choice for outdoor furniture $(55 \%)$, and lamps (54\%) were the least products preferred for hickory wood. This information could help secondary wood manufacturers to develop innovative designs on hardwood products where there is market acceptability for hickory wood.

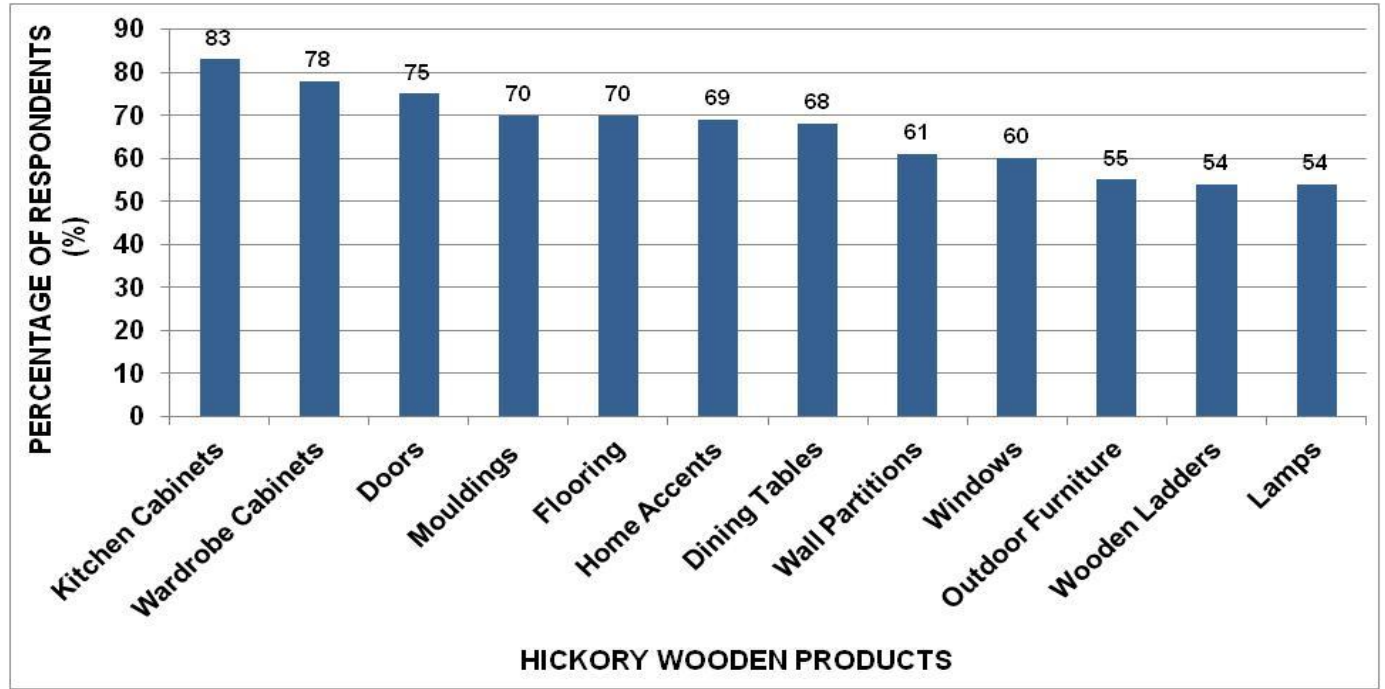

Figure 3.9 Hardwood products favored for hickory wood with natural finish. 


\subsubsection{Factors in wood purchasing decisions}

Respondents were asked to provide their level of concern for a variety of different factors that influence their wood purchasing decisions. Level of concern for each factor was assigned values on a 5 point Likert Scale ( $1=$ "Of no concern", 2= "Of little concern", 3= "Of moderate concern", 4= "Of greater concern", and $5=$ "Of greatest concern"). The average response values were used to rank the factors that influenced the respondents on purchasing decisions (Figure 3.10). In general, color (3.94) was the most influential factor that influenced purchasing decisions among the total American respondents. Similar with the previous study among the international community, color, wood finish, functionality \& safety were considered to be the top three most important factors.

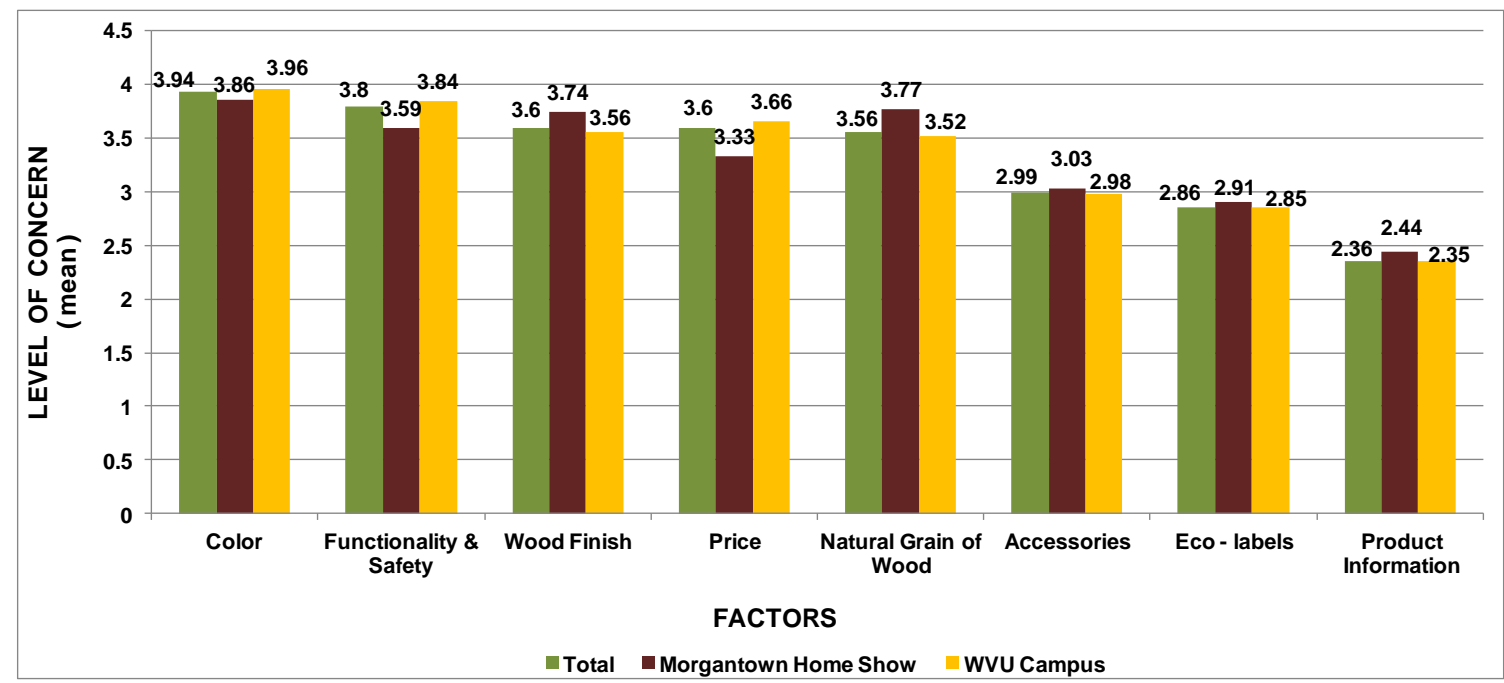

Figure 3.10 Factors that influenced the American respondents in wood purchasing decisions.

Differences in the response of WVU campus and Morgantown Home Show respondents were noticeable. Frequency report showed that respondents who attended the Morgantown Home Show had higher levels of concern with: natural grain (3.77), wood finish (3.74), accessories (3.03), eco-labels (2.91) and product information (2.44). Respondents from WVU Campus, showed greater 
concerns on: color (3.96), functionality \& safety (3.84), and price (3.66). Note that there are lower income group from WVU respondents since most of them were still undergraduates, thus price would definitely be a higher consideration. On the other hand, respondents from Morgantown Home Show would likely to purchase wooden products based on their purpose for the item furniture pieces regardless of price. Further investigation into whether Morgantown Home Show attendees have more intention or more interest to purchase wood products is highly recommended. The significance level was not statistically determined in this study due to huge difference on the sample size of the two groups.

The analysis of medians however, was used to further investigate differences in the level of concern for each factor when purchasing wood products among the total American respondents. In this study, the T-Test (test of two samples) procedure was performed using the Non-parametric (MannWhitney) test. Table 3.11, shows the factors which were statistically significant in the median wood purchasing decision of the local American respondents. This procedure indicated that while color was more of a concern, it was not statistically different from the median level of concern for functionality/safety. These results suggest that color and functionality/safety are of equal concern for the respondents when purchasing wood products. However, there was a statistically significant difference between median functionality/safety and wood finish. This result was consistent in the past study of Brinberg et al. (2007), where female American respondents were more particular on grain consistency and did not like wood blemishes. 
Table 3.11 Nonparametric (Mann-Whitney) test results for level of concern related to top priorities in wood purchasing decision factors among American respondents.

\begin{tabular}{|ccc|}
\hline Factors & Alternative & $\begin{array}{c}\text { T-test: Two Sample } \\
\text { Non - parametric } \\
\text { (Mann - Whitney ) Test } \\
\text { p-value }\end{array}$ \\
\hline $\begin{array}{c}\text { Color } \\
\text { Functionality/Safety } \\
\begin{array}{c}\text { Functionality/Safety } \\
\text { Wood Finish }\end{array}\end{array}$ & Diff $<>0$ & 0.430191 \\
$\begin{array}{c}\text { Wood Finish } \\
\text { Price } \\
\text { Color } \\
\text { Price }\end{array}$ & Diff $<>0$ & $0.014724^{*}$ \\
\hline
\end{tabular}

${ }^{*}$ indicates a statistically significant difference at alpha level $=0.05$.

It was interesting to note, that when buying wood products, the respondents considered color a more statistically significant concern than price. Past research has shown that color played an important role in the formation of consumer preferences on wood products (Nicholls et al. 2010). In terms of least concerning purchasing decision factors, product labels/information was of least concern for the Americans similar with the foreign nationalities.

It was observed, that there was a statistically significant difference on the level of concerns between the local and international community on the following factors: functionality/safety, wood finish, eco-label, and product label/information (Table 3.12). International respondents showed a higher level of concern on these factors as compared with the American respondents. American respondents showed a similar level of concern on color, price, natural grain and accessories with foreign nationalities when purchasing wood products. In comparison with the international community, both would purchase a valueadded wooden product based on their purpose regardless of the price. 
Table 3.12 Comparative results on the level of concern between international and local community on wood purchasing decision factors.

\begin{tabular}{|ccccc|}
\hline Factors & \multicolumn{2}{c}{$\begin{array}{c}\text { Level of Concern } \\
\text { (mean) }\end{array}$} & $\begin{array}{c}\text { Alternative } \\
\text { Hypothesis }\end{array}$ & $\begin{array}{c}\text { T-test: Two Sample } \\
\text { Non - parametric } \\
\text { (Mann - Whitney ) Test } \\
\text { p-value }\end{array}$ \\
\hline Functionality/Safety & 3.95 & 3.80 & Diff $<>0$ & $0.038756^{*}$ \\
Wood Finish & 3.80 & 3.60 & Diff $<>0$ & $0.010581^{*}$ \\
Color & 3.79 & 3.94 & Diff $<>0$ & 0.440812 \\
Price & 3.53 & 3.60 & Diff $<>0$ & 0.661476 \\
Natural Grain & 3.39 & 3.56 & Diff $<>0$ & 0.140642 \\
Eco-label & 3.17 & 2.86 & Diff $<>0$ & $0.009411^{*}$ \\
Accessories & 3.14 & 2.99 & Diff $<>0$ & 0.135592 \\
Product Labels/Info & 2.95 & 2.36 & Diff $<>0$ & $0.000005^{\star}$ \\
\hline
\end{tabular}

* indicates a statistically significant difference at alpha level $=0.05$.

\subsubsection{Sustainable product designs and concepts on hickory furniture}

Wood as a popular household material offers a feeling of naturalness because of its association from its origin (Jonsson et al. 2008). Johnson et al. (2008) pointed out that secondary wooden manufacturers should emphasize the positive aspects of solid wood. This may include but not limited to its naturalness, low degree of processing, and ability to offer a pleasant living surface. Character-marked features on wood furniture can still receive consumer acceptance, as long as it has great design (Wang et al. 2004, Brinberg et al. 2007).

The rustic look of hickory furniture was evaluated to determine whether or not this design style has market acceptability among the American respondents. Specifically, perceptions on furniture with tree bark designs were investigated. Out of 196 respondents, 35\% of the Americans answered MAYBE to purchasing these types of furniture. Table 3.13, further shows that Americans significantly perceived these designs as SUSTAINABLE (58\%) but OLD - FASHIONED $(84 \%)$. These results were pretty much the same among the international community, except that foreign nationalities would LIKELY to invest on these types of rustic look furniture. 
Table 3.13 Perceptions on hickory furniture products with tree bark remaining.

\begin{tabular}{|cccc|}
\hline Perceptions & $\mathrm{n}$ & $\%$ & $\mathrm{p}$-value \\
\hline $\begin{array}{c}\text { Will consider } \\
\text { investing }\end{array}$ & 196 & & \\
Not at all & & 18 & $0.0001^{*}$ \\
Unlikely & 22 & $0.0037^{*}$ \\
Maybe & 35 & $0.0000^{*}$ \\
Likely & 15 & $0.0000^{*}$ \\
Very Likely & 10 & $0.0000^{*}$ \\
\hline Sustainable & & $0.0017^{*}$ \\
Depleting & 182 & 58 & \\
\hline Modern & 42 & \\
Old - fashioned & 189 & & $0.0000^{*}$ \\
\hline
\end{tabular}

* indicates a statistically significant difference at alpha level $=0.05$.

a. Comparison of MAYBE to other responses.

\subsubsection{Emotional advertisements VS technical information on promotional messages}

Promotional marketing efforts are important for market acceptability of new wood. Table 3.14, shows the impacts of the promotional ads used to position hickory wooden products. Similar to the survey results in the international community, technical ads were more influential in regards to conveying the durability of hickory to the respondents as there was a statistically significant difference between the influence of the emotional ads and technical information with regards to durability ( $p$-value $=0.0000$ ). This suggests that emotional ads were not enough to give an impression that hickory wooden products were durable. This was supported by past research that advertisements cannot easily influence consumers' choice in the purchase of furniture (Pakarinen and Asikainen 2001). In relation to emotional ads, based on the survey results, only $41 \%$ Americans perceived hickory as being durable, despite of using significant events in American history. This finding indicated that Americans were not easily persuaded on the earlier accounts of the contributions of hickory throughout the history of the U.S. It was interesting to note that Americans were more affected 
with the technical information, despite the fact that majority of the respondents were not from the engineering major. This information would be very beneficial when marketing hickory wooden products in the domestic market.

With regards to the effectiveness of the two types of promotional messages, results indicated no statistically significant difference with regards to showing interest on the hickory wooden sample ( $p$-value $=0.8733$ ) and likely to purchase hickory wooden products ( $p$-value $=0.0942$ ).

Table 3.14 The impacts of the promotional ads used to position hickory wooden products among the American respondents.

\begin{tabular}{|c|c|c|c|}
\hline \multirow[b]{2}{*}{ Impacts } & \multicolumn{2}{|c|}{ Promotional Ads } & \multirow[b]{2}{*}{$\mathrm{p}$-value } \\
\hline & Emotional & Technical & \\
\hline a. Durability & $n=186$ & $n=198$ & \\
\hline No & $18 \%$ & $6 \%$ & \\
\hline Yes & $41 \%$ & $75 \%$ & $0.0000^{*}$ \\
\hline Not Sure & $41 \%$ & $19 \%$ & \\
\hline b. Interests on hickory wooden sample & $n=190$ & $n=194$ & \\
\hline No & $37 \%$ & $38 \%$ & \\
\hline Yes & $63 \%$ & $62 \%$ & 0.8733 \\
\hline c. Likely to purchase & $\mathrm{n}=188$ & $\mathrm{n}=193$ & \\
\hline No & $44 \%$ & $36 \%$ & \\
\hline Yes & $56 \%$ & $64 \%$ & 0.0942 \\
\hline
\end{tabular}

* indicates a statistically significant difference at alpha level $=0.05$.

Table 3.15, shows the percentage of respondents and their willingness to pay extra for wood products in various situations. In relation to hickory products, $74 \%, 84 \%$, and $88 \%$ of 190 respondents, indicated to pay extra if the product was made from hickory, had value-added features, and made in the USA, respectively. Based from this survey results, value-added features of the wood products were more important than the product being made of hickory. Furthermore, the sense of patronizing a local product (Made in the USA), despite 
additional costs was still highly favored. Promotional messages therefore for hickory wooden products, may include the origin of species to highlight its strengths in the local market.

Table 3.15 Willingness to pay extra for hickory wooden product.

\begin{tabular}{|l|c|c|c|c|c|c|}
\hline \multirow{2}{*}{\multicolumn{1}{c|}{ CONDITIONS }} & \multicolumn{6}{|c|}{ \% Extra Respondents Were Willing to Pay } \\
\cline { 2 - 8 } & 0 & $1-4$ & $5-9$ & $10-15$ & $16-20$ & $>20$ \\
\hline if made from hickory species & 26 & 18 & 25 & 22 & 6 & 3 \\
\hline with value - added features & 16 & 18 & 24 & 29 & 10 & 4 \\
\hline if Made in the USA & 12 & 11 & 15 & 26 & 13 & 22 \\
\hline
\end{tabular}




\subsection{CONCLUSION}

Similar to the results in the study of the international community, the top three most preferred species were: walnut, hickory and red oak. Most of the under-utilized species (hard maple, soft maple and yellow-poplar) however, were viewed as eco-friendly and sustainable. The preference for walnut of the American respondents was statistically significant based on gender and income. For age group 30 years old and above, results indicated no statistically significant evidence that under-utilized species (soft maple, hard maple, hickory and yellow poplar) were more preferred than other species (red oak and cherry). Yellow-poplar was the most successfully identified species by the American respondents. This finding was similar to the international respondents that also were most successful in identifying yellow-poplar. American respondents had trouble in distinguishing between soft and hard maple. Results showed no statistical significant difference in the identification of species based from the purchasing involvement for the last five years. The top 3 choices for the hickory hardwood products among the American respondents were: kitchen cabinets, wardrobe cabinets and doors. It was interesting to note that Americans were more influenced by the technical information than the emotional type of advertisements. There was no statistical significant difference between the median level of concerns for both the respondents in WVU Campus and Morgantown Home Show in their wood purchasing decisions. This suggests that, locations and interests do not affect American consumers when purchasing household wooden products. However, among the different factors, color was considered the most important factor in their wood purchasing decisions. This suggests that local community in the domestic market would likely purchase household wooden products based on fashion and trends. The furniture design with tree bark remaining was considered old-fashioned and sustainable. This therefore, could be a very good substitute for antique products. 


\subsection{REFERENCES}

Brinberg, D., M. Bumgardner, and K. Daniloski. 2007. Understanding perceptions of wood household furniture: application of a policy capturing approach. Forest Products Journal. 57(7/8):21-26.

Bowe, S., and M. Bumgardner. 2004. Consumers perceptions and knowledge of common furniture woods. USDA Forest Service: Proceedings 14th Central Hardwood Conference.Northeast Research Station: 404-410.

Bowe, S., and M. Bumgardner. 2004. Species selection in secondary wood products: Perspectives from different consumers. Wood and Fiber Science. 36(3): $319-328$.

Bowe, S., and M. Bumgardner 2002. Species selection in secondary wood products: Implications for product design and promotion. Wood and Fiber Science. 34(3): 408 - 418.

Buehlmann, M., M. Bumgardner, A. Schuler. and M. Barford. 2007. Assessing the impacts of global competition on the Appalachian hardwood industry. Forest Products Journal. 57(3):89-93.

Buehlmann, U., M. Bumgardner, A. Schuler, and K. Koenig. 2011. Housing and the Wood Industry, Trends and Market Conditions W \& WP. Woodworking Network.com, p.24

Bush,R.J, P.A. Araman, J.Jr. Muench. 1992. A Comparison of market needs to the species and quality composition of the US Hardwood Resource. Proceedings of an international conference Vancouver, British Columbia. Madison, WI: Forest Products Research Society. $234-240$.

Esty, D. and A. Winston. 2009. Green to Gold. How smart companies use environmental strategy to innovate, create value, and build competitive advantage, pp.15, 62-64, $101-303$.

Jonsson, O., S. Lindberg, A. Roos, M. Hugosson, and M. Lindstrom. 2008. Consumer perceptions and preferences on solid wood, wood-based panels, and composites: A repertory grid study. Wood and Fiber Science. 40(4):663 - 678.

Nicholls, D. and M. Bumgardner. 2007. Evaluating selected demographic factors related to consumer preferences for furniture from commercial and from underutilized species. Forest Products Journal. 57(12): $79-82$.

Nicholls, D. and M. Bumgardner, V. Barber. 2010. Consumer and manufacturer perceptions of hardwood panels made from character - marked lumber. International Wood Products Journal. 1(1): $28-34$.

Lages, FL., JL. Abrantes, RC. Lages. 2008. The STRATADAPT scale: A measure of marketing strategy adaptation to international business markets. International Marketing Review. 25(5): $584-600$.

Ozanne, L. and P. Smith. 1996. Consumer segments for environmentally marketed wooden household furniture. Wood and Fiber Science. 28 (4):461 - 477.

Pakarinen T.J. and A.T. Asikainen. 2001. Consumer segments for wooden household furniture. Holz als Roh - und Werkstoff 59(2001): 217-227.

Scholz W.S. and R. Decker. 2007. Measuring the impact of wood species on consumer preferences for wooden furniture by means of the Analytic Hierarchy Process. Forest Products Journal. 57(3): $23-28$.

Wang Q., G. Shi, C. Chan - Halbrendt. 2004. Market potential for fine furniture manufactured from low - grade hardwood: Evidence from a conjoint analysis in the northeastern United States. Forest Products Journal. 54(5):19-25. 


\section{CHAPTER 4. SUMMARY}

To maximize timber market potential, problems related to increasing value and use of low grade lumber and low valued Appalachian hardwoods requires a thorough investigation. The use of other under-utilized hardwood species in the Appalachian region will assist in active forest resource management (i.e. scarcity prevention of resources, balance of ecosystem, and sustainable forest development). Improving markets for low-value Appalachian hardwoods is vital for the transition of the Appalachian Region's economy towards sustainable growth and development. Under-utilized tree species could serve as substitute materials that would play greater role in coming up with less expensive wood products. Results from this study on international and domestic market perceptions will help secondary wooden manufacturers to capitalize on under-utilized species that are both available locally and meet consumer's needs. Improved market potentials are possible for under-utilized Appalachian hardwoods.

In the case of hickory, a niche high-end market can be streamlined through product differentiation, and by targeting price points most favorable to the consuming public. In many instances, hickory was found to have a competitive advantage over other commercial wooden species. Hickory was the only under-utilized species that was chosen as the top most preferred species and was viewed favorably when compared to walnut and red oak. The presence of value-added features on hickory products were viewed as being more significant than price. A majority of the respondents recognized the differences in wood samples with different finishes applied. However, in the case of hickory with spice finish and red oak with honey spray finish, a majority of the respondents viewed these two samples as the same species. This finding indicted that hickory heartwood (with little color variation), when stained in a certain fashion, may be an acceptable replacement for red oak. Furthermore, this indicated that investment in lumber sorting and wood finishing techniques could help assist hickory in being an alternative material for markets where red oak is important. A going back to nature trend appears to be increasing within 
the furniture market. Hickory wood products with tree bark remaining were perceived to be old fashioned but sustainable. In this green economy, the low stumpage price of hickory over the other popular species can be seen now as strength. Lumber sorting and wood finishing techniques could help increase hickory's potential as an alternative species over other commercial species. Investment in hickory timber is encouraged while the stumpage price is still low and could result in opportunities during this economic downturn. Product orientation on hickory wood among designers, distributors and consumers is highly important to expose all marketing potentials of hickory wood. The wood products that the respondents most favored when using hickory were: doors, kitchen cabinets, and wardrobe cabinets. Hickory was also viewed as having potential for moulding, dining tables, flooring and wooden ladders.

Promotional efforts related to under-utilized species and wood product positioning should be developed in a manner to meet the needs of the target market. To fully implement a strong promotional campaign requires knowledge related to the current perceptions of Appalachian hardwoods and factors that influence consumer purchasing. Respondents reacted more favorably to technical information ads over advertisements that used emotional appeal. A combination of the two could be the best form of promotional messages, however, since both methods were found to be effective in promoting hickory products. It was determined that respondents had a willingness to buy hickory products and products Made in the USA at a higher price. The results of this study indicated that both the international and American communities were most concerned with functionality and safety, wood finish, and color, more so than price. Most of the under-utilized species (soft maple, hard maple and yellowpoplar) were viewed as eco-friendly and sustainable species. Secondary wood product manufacturers should capitalize on these wood attributes as strengths when marketing their products. Overall, this study was able to identify various current perceptions related to Appalachian hardwoods. By using this information, hardwood product manufacturers within Appalachia should be more equipped to market their products successfully in the emerging green economy. 


\section{APPENDIX}

\section{SURVEY RESEARCH INSTRUMENTS AND OBSERVATIONS}

\subsection{Market Research Survey Questionnaire}

1.2 American Patriotic Playing Card

1.3 Photos of furniture collection with tree bark remaining

1.4 Photos of wooden samples on species recognition with correct answer

1.5 Qualitative observations (International vs. American respondents) 
Appendix 1.1 Market Research Survey Questionnaire

\section{Expanded Market Opportunities of Appalachian Hardwoods}

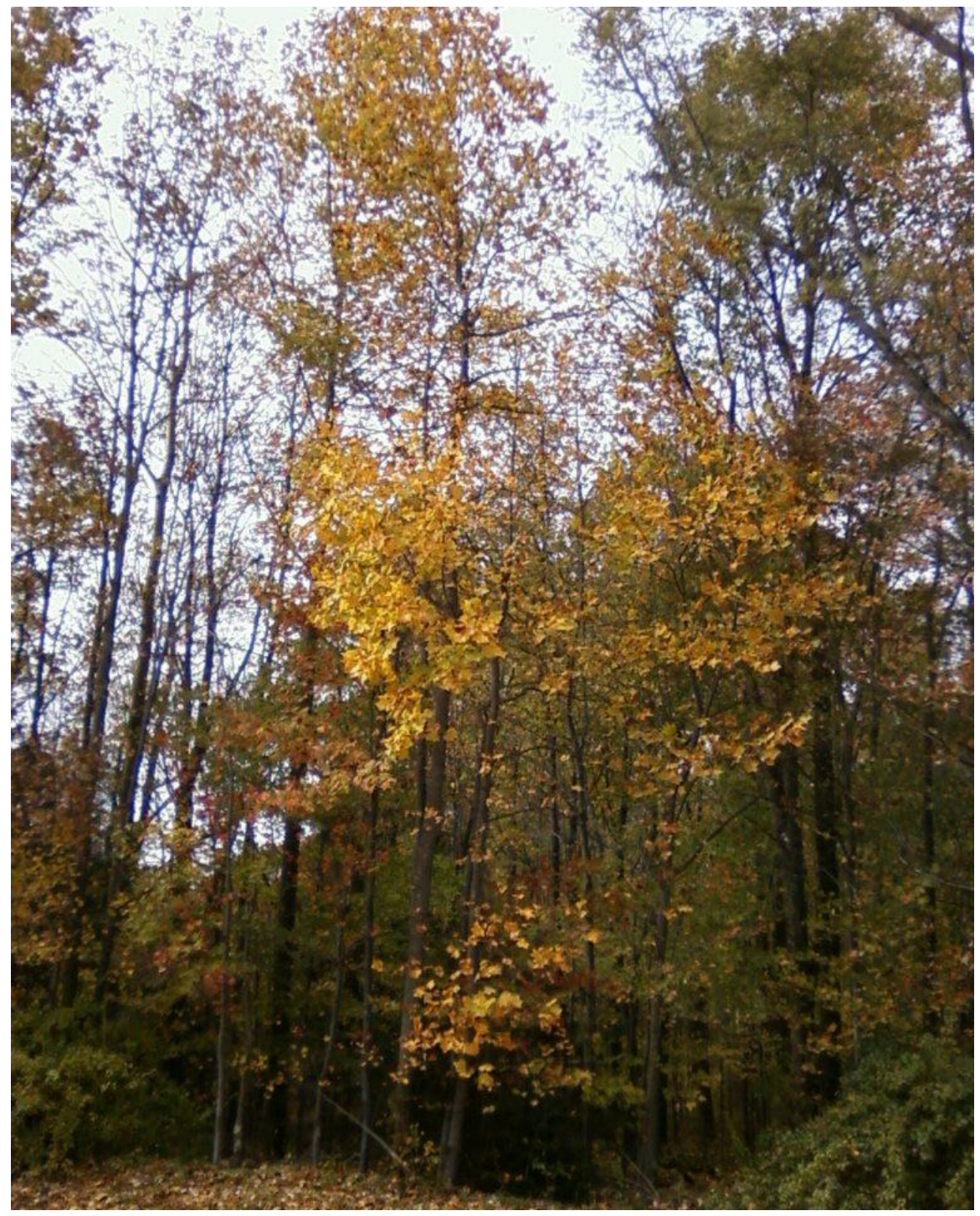

WWestVirginiaUniversity.

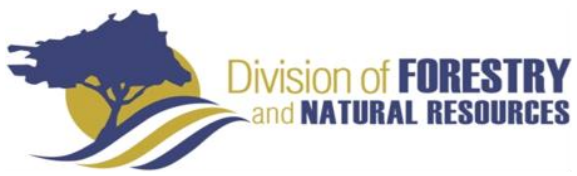




\title{
WestVirginiaUniversity
}

\author{
Davis College of Agriculture, Natural Resources and Design
}

Percival Hall Building, Morgantown, WV 26506 - 6125

February 26, 2012

Dear Sir/Madam:

I am seeking your help on a research project to investigate on how to improve the market potential of Appalachian Hardwoods, which are abundant in the region. Your knowledge and consumer preferences are critically important in helping us better understand consumer's needs and expectations from the wood products they purchase. We would appreciate you taking a moment to participate in this survey.

Participating in filling out the questionnaire is voluntary and you do not need to answer all the questions. Also, you can quit filling out the questionnaire (i.e., quit the study) at any time. To participate in the study, you must be 18 years of age or older.

Results from this survey will be used to evaluate the current demand for the various Appalachian hardwood species and to gain a better understanding of the impediments to their marketability. Moreover, the results from this study will provide consumer data that can assist secondary wood product manufacturers in making decisions related to material selection, product innovation and marketing strategies.

Your answers will be treated with complete confidentiality and will not be linked to you or your business in the final report of the study results. West Virginia University's Institutional Review Board (IRB) has acknowledgment of this study on file. If you need further information related to this study, the Primary Investigator is Dr. David DeVallance (Assistant Professor in WVU's Division of Forestry and Natural Resources) and he can be reached by telephone at 304/293-0029 or by email at david.devallance@mail.wvu.edu.

Thank you in advance for your assistance. If you have any questions, please feel free to contact me.

Sincerely,

Liberty Olea Moya

Graduate Research Assistant

Forest Products Marketing, Wood Science and Technology Department

Division of Forestry and Natural Resources

West Virginia University, Morgantown, WV 26506

Telephone No. : 304-293-0039

Email: 1moya@mix.wvu.edu 
Survey Questionnaire:

Please check or specify the following that best corresponds to your answer.

\section{A. Demographics}

Nationality:

Status: $\square$ Single $\square$ Married $\quad$ Gender: $\square$ Female $\square$ Male

Age: $\square 18-23 \quad \square 24-29 \quad \square 30-35 \quad \square 36-40 \quad \square>40$

Occupation: $\square$ Graduate Student $\quad \square$ Faculty Member $\quad \square$ Other

Educational Status: $\square$ Undergraduate $\quad \square$ Vocational/Certificate $\square$ A.B/B.S $\quad \square$ M.S. $\square \mathrm{Ph} . \mathrm{D}$.

Major: $\square$ Engineering $\quad \square$ Forestry $\quad \square$ Psychology

$\square$ Architecture/Design $\quad \square$ Marketing Others

Household income per month:

$\square<\$ 1,250 \quad \square \$ 1,251-\$ 3,500 \quad \square \$ 3,501-\$ 5,000 \quad \square \$ 5,001-\$ 7,500 \quad \square>7,500$

Do you own a house? $\square$ Yes $\quad \square$ No

Do you have experience in working with wood products? $\square$ Yes $\quad \square$ No

Have you been involved in the purchase of furniture during the last 5 years? $\square$ Yes $\quad \square$ No 


\section{B. Species Determination (Please refer to wood sample boards A - G).}

I. Kindly check which do you think the following species are, based on your own thoughts or perceptions.

\begin{tabular}{|c|l|l|l|l|l|l|l|}
\hline SPECIES & A & B & C & D & E & F & G \\
\hline Cherry & & & & & & & \\
\hline Hickory & & & & & & & \\
\hline Soft Maple & & & & & & & \\
\hline Hard Maple & & & & & & & \\
\hline Red Oak & & & & & & & \\
\hline Walnut & & & & & & & \\
\hline Yellow Poplar & & & & & & & \\
\hline
\end{tabular}

II. Kindly rank in-order the following wood samples according to your own preferences, when purchasing wooden products based on their physical look (1= Most Liked; 7 = Least Liked):

\begin{tabular}{|l|l|l|l|l|l|l|}
\hline $\mathbf{A}$ & $\mathbf{B}$ & $\mathbf{C}$ & $\mathbf{D}$ & $\mathbf{E}$ & $\mathbf{F}$ & $\mathbf{G}$ \\
\hline & & & & & & \\
\hline
\end{tabular}

III. Please rank in-order the TOP 3 wood samples of your choice (1= Most Liked) in terms of:

\begin{tabular}{|c|c|c|c|c|c|c|c|}
\hline \multirow{2}{*}{ Attributes } & \multicolumn{7}{|c|}{ Wood Samples } \\
\hline & A & B & C & D & E & & G \\
\hline 1. Durability & & & & & & & \\
\hline $\begin{array}{ll}\text { 2. } & \text { Expensive } \\
\text { Look }\end{array}$ & & & & & & & \\
\hline 3. Elegant Design & & & & & & & \\
\hline 4. Formal Look & & & & & & & \\
\hline
\end{tabular}

\begin{tabular}{|l|l|l|l|l|l|l|l|}
\hline \multirow{2}{*}{ Attributes } & \multicolumn{6}{|c|}{ Wood Samples } \\
\cline { 2 - 8 } & A & B & C & D & E & F & G \\
\hline 5. Modern Style & & & & & & & \\
\hline 6. Calming Effect & & & & & & & \\
\hline 7. Eco-friendly & & & & & & & \\
\hline
\end{tabular}

C. In terms of wood finish, which do you prefer most? Refer to wood samples H\&I.

$\square$ glossy/shiny finish (Sample H) $\quad \square$ matte/natural look of the wood (Sample I) 


\section{Given the actual appearance of wood sample I, will you consider using it for your:}

Flooring $\square$ Yes $\quad \square$ No Kitchen Cabinets $\quad$ Yes $\quad$ No $\quad$ Wooden Ladders $\square$ Yes $\square$ No

Doors $\quad$ Yes $\square$ No Dining Tables $\quad$ Yes $\square$ No Wall Partitions $\square$ Yes $\square$ No

Windows $\square$ Yes $\quad$ No Wardrobe Cabinets $\square$ Yes $\square$ No Lamps $\quad \square$ Yes $\square$ No

Mouldings $\square$ Yes $\quad \square$ No Outdoor Furniture $\quad \square$ Yes $\quad \square$ No Home Accents $\quad \square$ Yes $\quad$ No

E. Please see the furniture on display. Kindly indicate your level of concern with each of the following "factors", in terms of your wood purchasing decisions:

\begin{tabular}{|c|c|c|c|c|c|}
\hline Factors & $\begin{array}{l}\text { Of no } \\
\text { concern }\end{array}$ & $\begin{array}{l}\text { Of little } \\
\text { concern }\end{array}$ & $\begin{array}{c}\text { Of } \\
\text { moderate } \\
\text { concern }\end{array}$ & $\begin{array}{c}\text { Of } \\
\text { greater } \\
\text { concern }\end{array}$ & $\begin{array}{c}\text { Of } \\
\text { greatest } \\
\text { concern }\end{array}$ \\
\hline a) Price & 0 & O & 0 & 0 & $\bigcirc$ \\
\hline b) Wood Finish & $\bigcirc$ & 0 & $\bigcirc$ & $\bigcirc$ & $\bigcirc$ \\
\hline c) Color & 0 & 0 & $\bigcirc$ & $\bigcirc$ & $\bigcirc$ \\
\hline d) Natural grain of wood & $\bigcirc$ & $\bigcirc$ & 0 & $\bigcirc$ & $\bigcirc$ \\
\hline e) Item functionality \& safety & $\bigcirc$ & $\bigcirc$ & $\bigcirc$ & $\bigcirc$ & $\bigcirc$ \\
\hline $\begin{array}{l}\text { f) Accessories } \\
\text { (hardware/s, fabrics) }\end{array}$ & O & $\Omega$ & $\bigcirc$ & $\bigcirc$ & O \\
\hline $\begin{array}{l}\text { g) With eco - label } \\
\text { certifications (wood was } \\
\text { harvested using sustainable }\end{array}$ & $\bigcirc$ & $\mathrm{O}$ & O & $\bigcirc$ & $\bigcirc$ \\
\hline $\begin{array}{l}\text { h) Product labels and } \\
\text { information (advertisements) }\end{array}$ & $\bigcirc$ & $\mathrm{O}$ & O & $\mathrm{O}$ & $\mathrm{O}$ \\
\hline
\end{tabular}

F. Please check whether the following wood samples are of same species?
a. 1 and $2 \quad \square$ Yes $\square$ No
d. 7 and $8 \quad \square$ Yes $\square$ No
f. 11 and $12 \quad \square$ Yes $\square$ No
b. 3 and $4 \quad \square$ Yes $\quad \square$ No
e. 9 and $10 \quad \square$ Yes $\square$ No
g. 13 and $14 \quad \square$ Yes $\square$ No
c. 5 and $6 \quad \square$ Yes $\square$ No 


\section{G. Based from the photos of the furniture collection shown:}

1. How likely will you consider investing on furniture products that have the tree bark remaining?

\begin{tabular}{|c|c|c|c|c|}
\hline Not at all & Unlikely & Maybe & Likely & $\begin{array}{c}\text { Very } \\
\text { Likely }\end{array}$ \\
\hline$\bigcirc$ & $\bigcirc$ & $\bigcirc$ & $\bigcirc$ & $\bigcirc$ \\
\hline
\end{tabular}

2. Do you think the furniture product designs that have the tree bark remaining are:

$\square$ More sustainable $\quad \square$ Depleting

3. How do you view these furniture collections that have the tree bark remaining?

$\square$ Modern $\quad \square$ Old-Fashioned

\section{H. Please read the below statements:}

Hickory has a long history of usefulness in the United States. The main uses for hickory include: furniture, sporting equipment, flooring, handles for construction equipment, and as a heating fuel. Hickory offers an efficient combination of strength, durability, hardness, and elasticity. Historically, most wagon wheels were made from hickory. The late US President, Andrew Jackson, was nicknamed "Old Hickory" because of his toughness in times of crisis. Hickory furniture was a most sought item pieces in the early days. These furniture can still be found in the lodges of many US National Parks, such as Yellowstone, Yosemite, and the Grand Canyon. The use of rustic-type hickory furniture extends the feel of nature to indoor spaces.

\section{Based on the given information:}

1. Do you consider Hickory to be the most durable among the wood samples?

$\square$ Yes $\quad \square$ No $\quad \square$ Not Sure

2. Are you more likely to purchase products produced from hickory? $\square$ Yes $\square$ No

3. Are you interested in knowing which among the sample boards is hickory? $\square$ Yes $\quad \square$ No 


\section{Based on your perceptions of wood products:}

1. How much more would you be willing to pay extra for a product if it is made from hickory?

$\square 0 \% \quad \square 1-4 \% \quad \square 5-9 \% \quad \square 10-15 \% \quad \square 16-20 \% \quad \square>20 \%$

2. How much more would you be willing to pay extra for a hickory product that has valueadded features (e.g., extra features, multi-functional)?

$\square 0 \% \quad \square 1-4 \% \quad \square 5-9 \% \quad \square 10-15 \% \quad \square 16-20 \% \quad \square>20 \%$

3. How much more would you be willing to pay for a wood product if it is "MADE IN USA"?

$\square 0 \% \quad \square 1-4 \% \quad \square 5-9 \% \quad \square 10-15 \% \quad \square 16-20 \% \quad \square>20 \%$

\section{J. Please read the following technical information:}

\begin{tabular}{|c|c|c|c|c|c|c|c|}
\hline & \multicolumn{9}{|c|}{ Species } \\
\cline { 2 - 9 } $\begin{array}{c}\text { Property at 12\% Moisture } \\
\text { Content }\end{array}$ & $\begin{array}{c}\text { Yellow- } \\
\text { poplar }\end{array}$ & $\begin{array}{c}\text { Hickory } \\
\text { (Pignut } \\
\text { hickory) }\end{array}$ & $\begin{array}{c}\text { Oak } \\
\text { (Northern } \\
\text { Red) }\end{array}$ & $\begin{array}{c}\text { Soft Maple } \\
\text { (Red) }\end{array}$ & $\begin{array}{c}\text { Hard } \\
\text { Maple } \\
\text { (Sugar) }\end{array}$ & $\begin{array}{c}\text { Black } \\
\text { Walnut }\end{array}$ & $\begin{array}{c}\text { Cherry } \\
\text { (Black) }\end{array}$ \\
\hline Specific Gravity & 0.42 & 0.75 & 0.63 & 0.54 & 0.63 & 0.55 & 0.50 \\
\hline $\begin{array}{c}\text { Bending Strength (Ib/in }{ }^{2} \text { ) } \\
\text { Compression Parallel to } \\
\text { Grain (lb/in') }\end{array}$ & 10,100 & 20,000 & 14,300 & 13,400 & 15,800 & 14,600 & 12,300 \\
\hline Impact Bending (in.) & 24 & 74 & 43 & 32 & 39 & 34 & 29 \\
\hline
\end{tabular}

\section{Based on the given technical information:}

1. Do you consider Hickory to be the most durable among the wood samples?

$\square$ Yes $\quad \square$ No $\quad \square$ Not Sure

2. Are you more likely to purchase products produced from hickory? $\square$ Yes $\square$ No

3. Are you interested in knowing which among the sample boards is hickory? $\square$ Yes $\square$ No

Other comments and suggestions when purchasing wooden products:

Thank you for completing the survey. Your help will surely go a long way.

LOM 03/02/2012 
Appendix 1.2 The American Patriotic Playing Card which was given to those who participated in the survey.

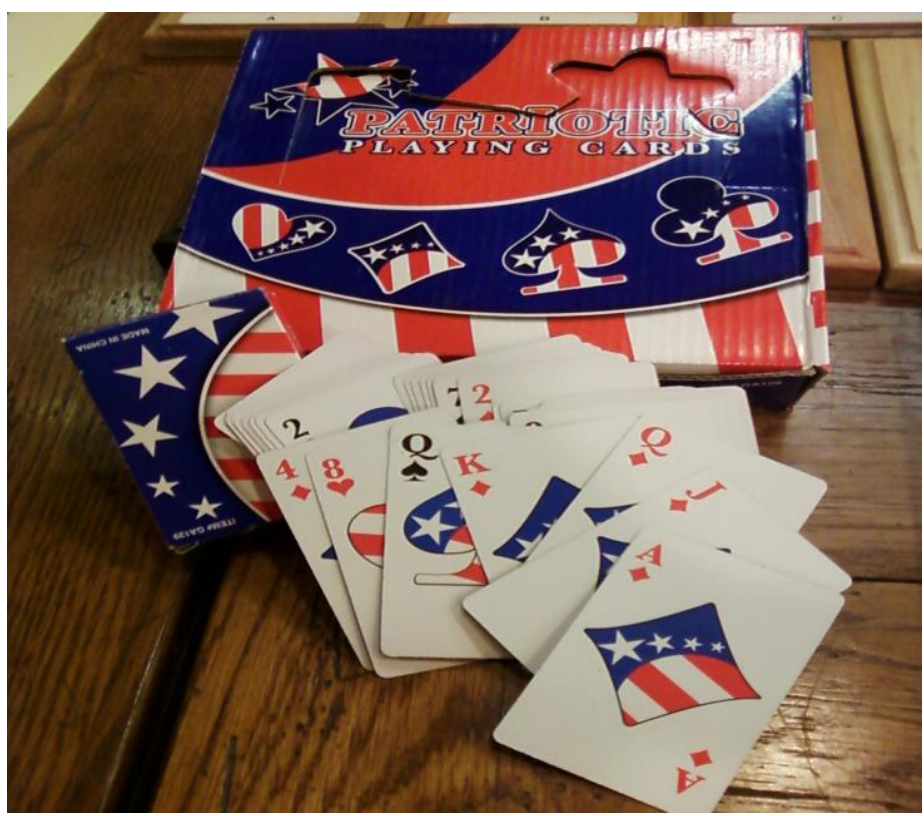


Appendix 1.3 Unfinished back portions of the wooden sample boards used in species recognition (unlabeled during the conduct of survey experiments).
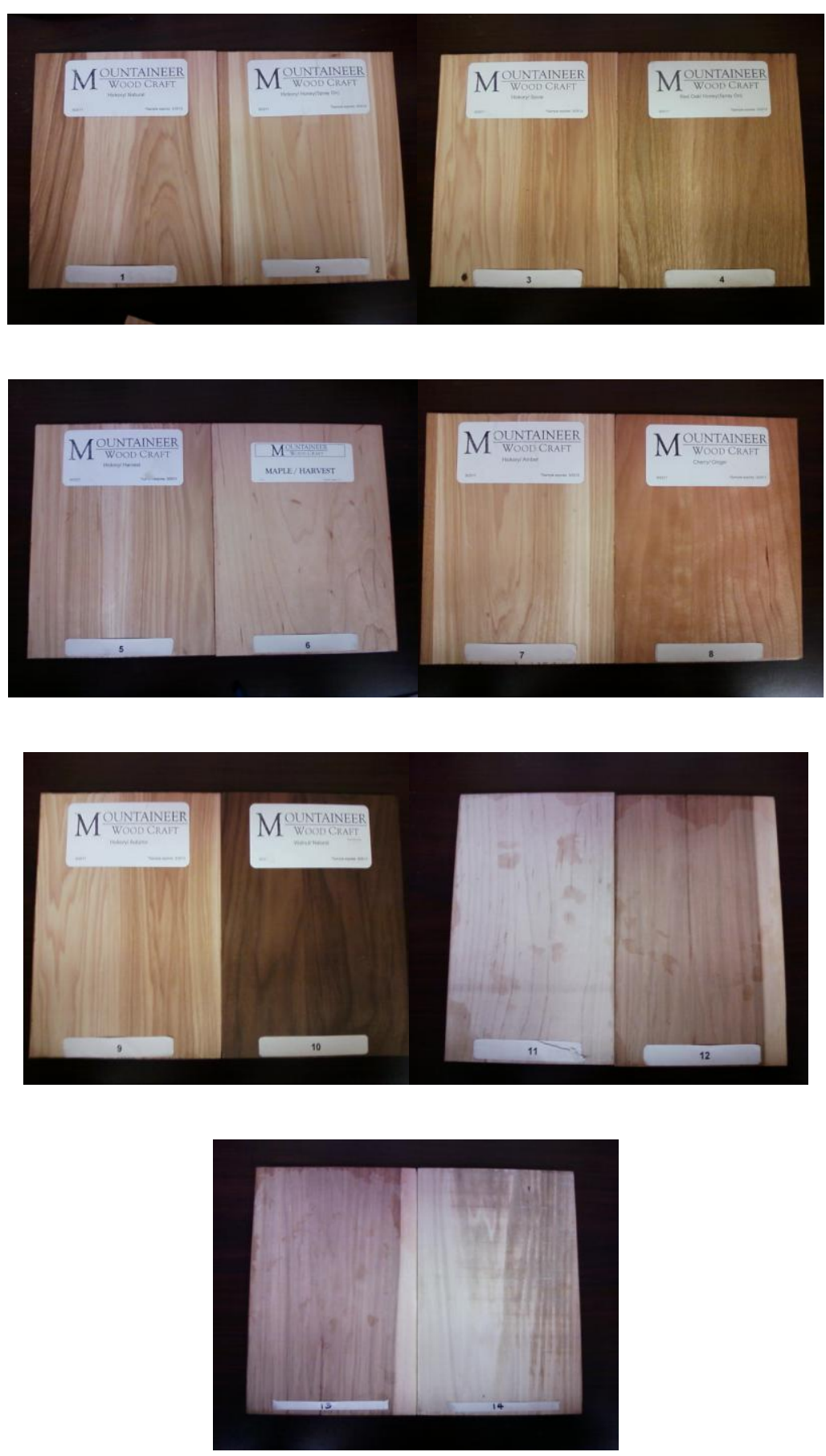
Appendix 1.4 A poster of furniture collection "without and with" the tree bark remaining was shown to the respondents to check current insights on hickory product designs.

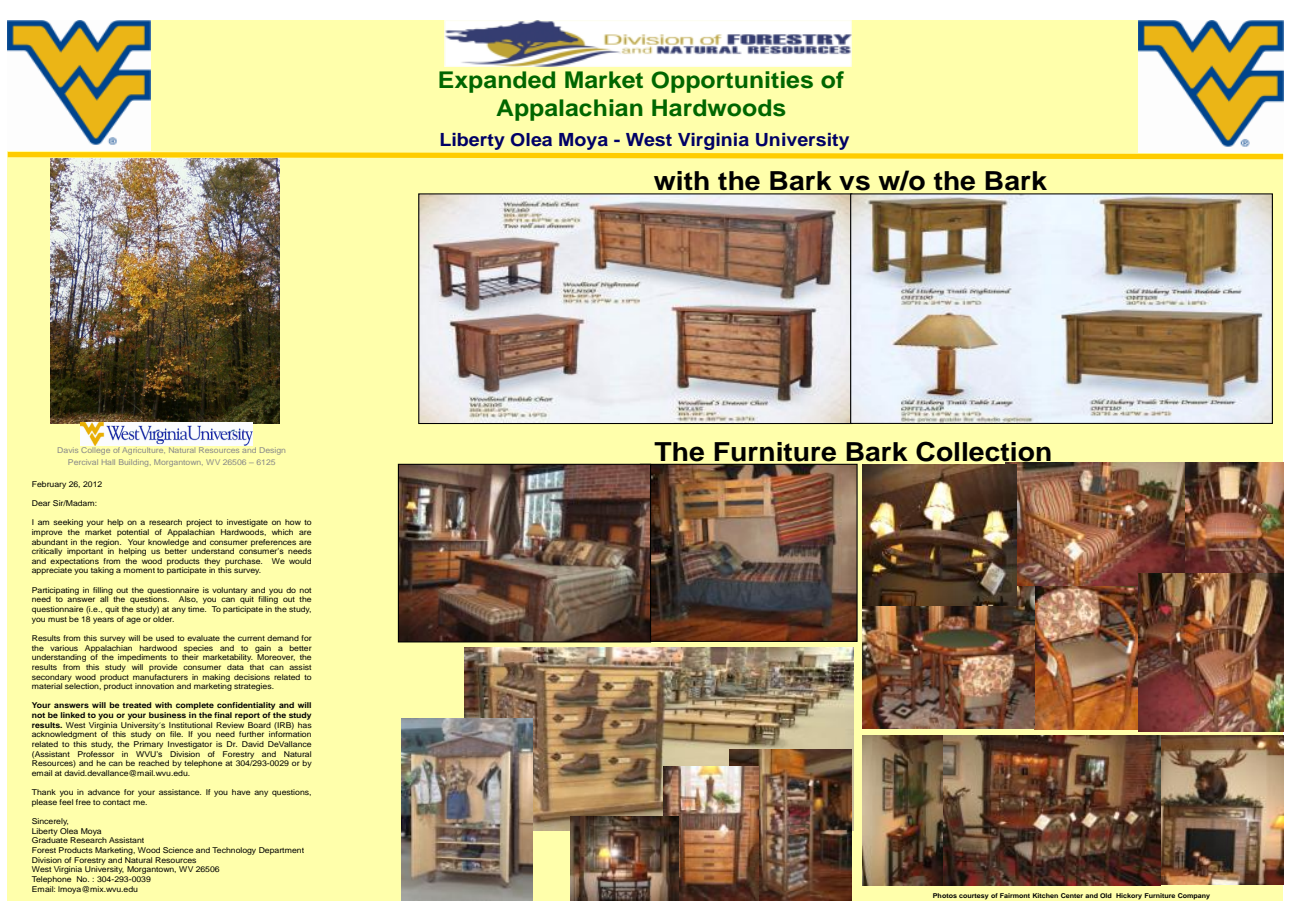




\section{Appendix 1.5 Qualitative Observations}

These observations could be due to differences in cultural perceptions, social responsibility, beliefs, and values of an individual respondent.

\section{International Community}

It was observed that foreign nationalities tend to use their senses of sight, touch, hearing and smell during wood identification. Some of them knocked or pricked on wooden samples to distinguish Soft Maple from the Hard Maple. Others smelled the sample boards when it was time to determine which were Cherry and Walnut, as the species suggested a name of the fruit and a nut respectively. Walnut was also often associated to darker color of wood because of its association with the color of a chocolate. Although, these findings were not statistically tested, it was observed that the English names and colors of the wooden species were associated with the actual look of the species. For instance, some based their answers from the color of the wooden samples. It was also observed that international respondents were very keen while determining the wooden species when applied with wood finish. They examined even the back of the wooden samples. It was also noticeable that international community have tendency to discuss things out among their colleagues before answering the survey. This exhibits a strong sense of being in a social society.

\section{American respondents}

It was noticeable how the "female respondents" had a big influence to their male partners when purchasing household wooden products. Husbands tend to seek first the opinion of their wives even if they liked already the hickory wooden sample. Perhaps, this could be due to the equal treatment between man and woman in the USA. Few of the respondents too, were observed with great concern for the environment and had reluctance in the usage of wooden products. 